\title{
17. UNCONFORMABLE SEQUENCE BOUNDARIES AT DEEP SEA DRILLING PROJECT SITE 612, NEW JERSEY TRANSECT: THEIR CHARACTERISTICS AND STRATIGRAPHIC SIGNIFICANCE ${ }^{1}$
}

\author{
C. Wylie Poag and Doris Low, U.S. Geological Survey, Woods Hole ${ }^{2}$
}

\begin{abstract}
On the basis of lithologic, foraminiferal, seismostratigraphic, and downhole logging characteristics, we identified seven distinctive erosional unconformities at the contacts of the principal depositional sequences at Site 612 on the New Jersey Continental Slope (water depth $1404 \mathrm{~m}$ ). These unconformities are present at the Campanian/Maestrichtian, lower Eocene/middle Eocene, middle Eocene/upper Eocene, upper Eocene/lower Oligocene, lower Oligocene/upper Miocene, Tortonian/Messinian, and upper Pliocene/upper Pleistocene contacts. The presence of coarse sand or redeposited intraclasts above six of the unconformities suggests downslope transport from the adjacent shelf by means of sediment gravity flows, which contributed in part to the erosion. Changes in the benthic foraminiferal assemblages across all but the Campanian/Maestrichtian contact indicate that significant changes in the seafloor environment, such as temperature and dissolved oxygen content, took place during the hiatuses.

Comparison with modern analogous assemblages and application of a paleoslope model where possible, indicate that deposition took place in bathyal depths throughout the Late Cretaceous and Cenozoic at Site 612. An analysis of two-dimensional geometry and seismic facies changes of depositional sequences along U.S.G.S. multichannel seismic Line 25 suggests that Site 612 was an outer continental shelf location from the Campanian until the middle Eocene, when the shelf edge retreated $130 \mathrm{~km}$ landward, and Site 612 became a continental slope site. Following this, a prograding prism of terrigenous debris moved the shelf edge to near its present position by the end of the Miocene.

Each unconformity identified can be traced widely on seismic reflection profiles and most have been identified from wells and outcrops on the coastal plain and other offshore basins of the U.S. Atlantic margin. Furthermore, their stratigraphic positions and equivalence to similar unconformities on the Goban Spur, in West Africa, New Zealand, Australia, and the Western Interior of the U.S. suggest that most contacts are correlative with the global unconformities and sea-level falls of the Vail depositional model.
\end{abstract}

\section{INTRODUCTION}

Publication of the Vail depositional model, in which sequences are bounded by unconformities of interregional or even global extent (Vail et al., 1977; 1984), has focused renewed attention on gaps in the stratigraphic record (e.g., Schlee, 1984; Poag et al., 1985). Continuously cored boreholes drilled along multichannel seismic reflection profiles can provide the essential documentation, lacking in Vail's papers, of relationships between seismic reflection, geophysical logging, lithologic, and faunal characteristics of such unconformities. Poag et al. (1985), for example, carried out a systematic study of four distinctive unconformities cored at DSDP Site 548 on Goban Spur, a seafloor prominence on the continental slope of Ireland (Graciansky, Poag, et al., 1985a, 1985b). These authors concluded that each of the four unconformities was represented by coincident biostratigraphic, lithologic, stable isotopic, and seismic-reflection discontinuities. Furthermore, the stratigraphic position of each unconformity correlates with a major global unconformity and a sea-level fall of the Vail model. Generally, they found that paleoenvironmental conditions began to shift prior to the onset of submarine erosion that created the unconformities at Site 548. Following each

\footnotetext{
${ }^{1}$ Poag, C. W., Watts, A. B., et al., Init. Repts. DSDP, 95: Washington (U.S. Govt. Printing Office)

2 Addresses: U.S. Geological Survey, Woods Hole, MA 02543.
}

erosional episode, sedimentation resumed in the form of a fine-grained turbidite, derived from nearby upper-slope sources. Poag et al. postulated that the unconformities may have been produced, in part, by the erosive force of a turbulent boundary layer, which separated North Atlantic Deep Water and Mediterranean Outflow Water, and which rose and fell across Site 548 in concert with sea-level rise and fall.

The initial shipboard identification of major unconformities at Site 612 on the New Jersey Slope (Fig. 1) indicated that they, too, generally correspond with global unconformities and low sea levels of the Vail model, and that several are equivalent to the Goban Spur unconformities. Also, they could be traced updip to the continental shelf, where they form part of the stratigraphic framework discussed by Poag and Schlee (1984) and Poag (1985a) (Fig. 2). This chapter provides further documentation for the geological and geophysical characteristics of these unconformities and their enclosing strata, especially emphasizing their genesis, implications of paleoenvironmental change, and regional relationships. An analysis of sedimentological characteristics, derived from thin sections at several of these same unconformities, is presented by Cousin and Thein (this volume).

\section{METHODS OF FAUNAL ANALYSIS}

Poag et al. (1985) took two to four samples of $20-\mathrm{cm}^{3}$ volume at irregular intervals above and below the unconformities at Site 548. We used a more systematic approach to sampling at Site 612, attempting thereby to identify the "normal" (background) lithic and faunal characteristics of strata above and below the unconformable contacts and 
A

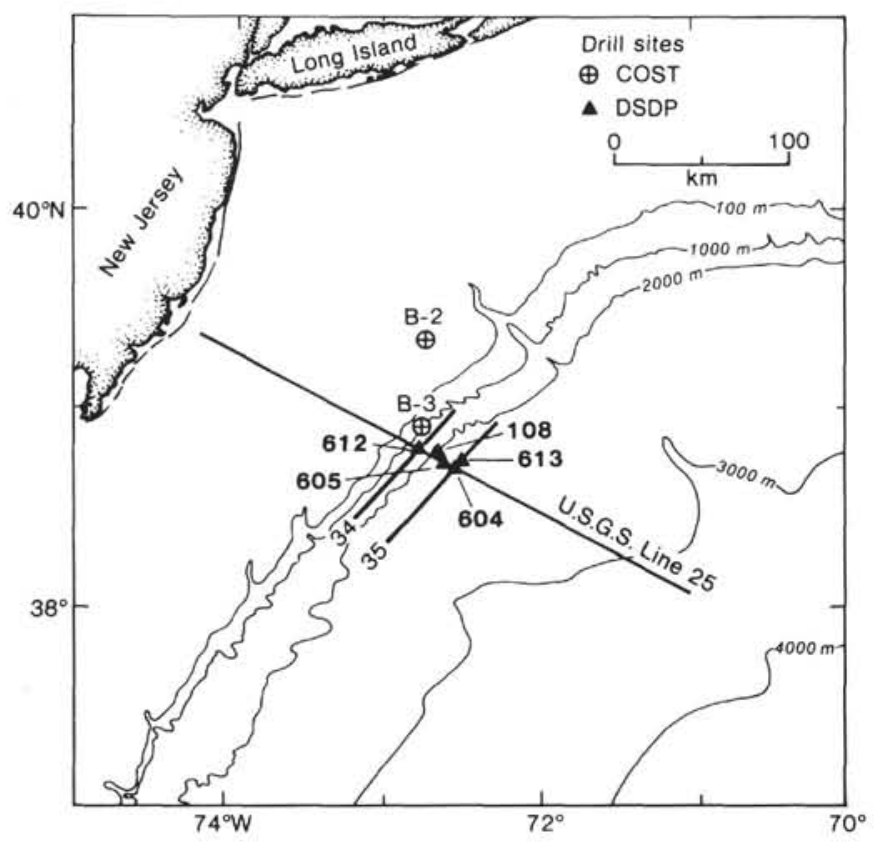

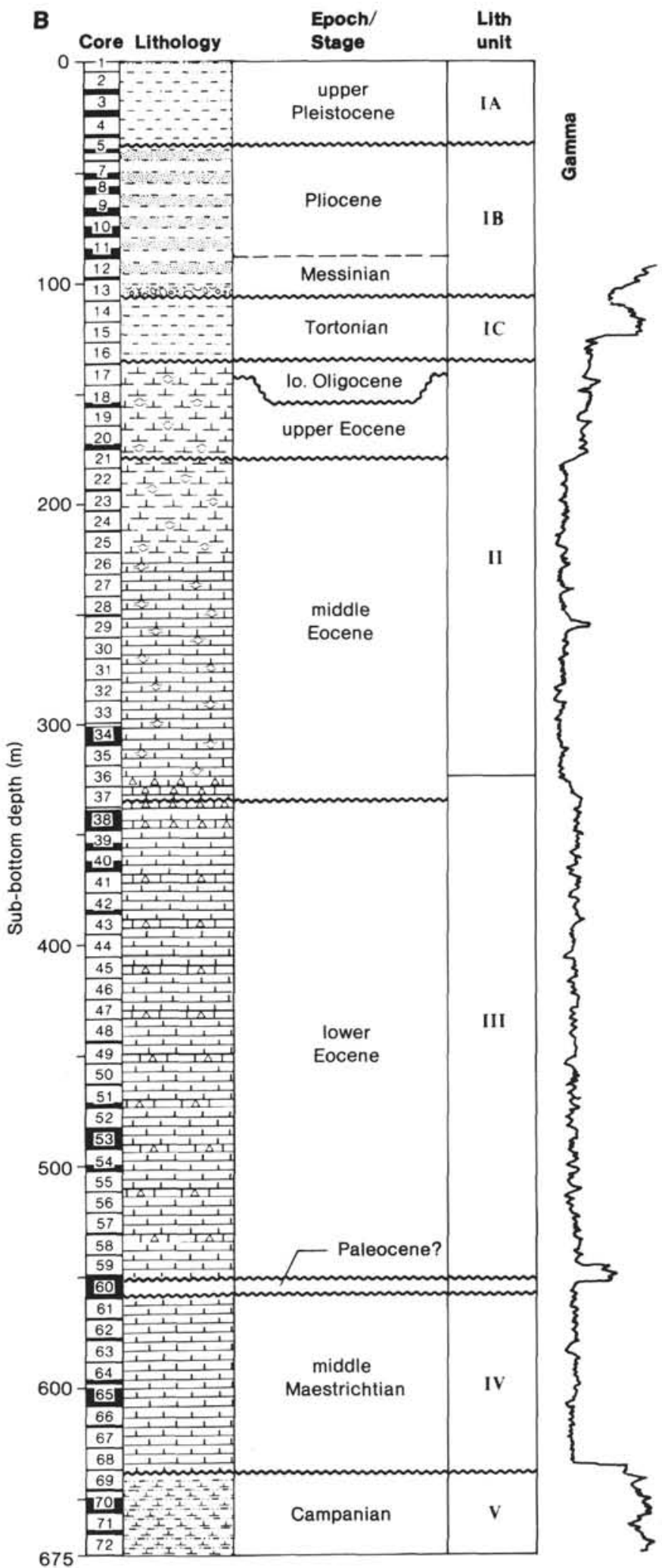

675

Figure 1. A. Location map of principal boreholes and U.S.G.S. multichannel Line 25 on New Jersey continental slope and rise. COST $=$ Continental Offshore Stratigraphic Test well. B. Stratigraphic column for Site 612 showing epoch/stage, lithology, core numbers, and lithologic units (Roman numerals). Gamma ray log at right increases in value to the right. Irregular boundaries indicate unconformities. C. Interpretation of stratigraphy and projection of boreholes along Line 25 (continental slope and rise segment). ASP = Atlantic Slope Project. Pre-Campanian stratigraphy from Poag (1985a). D. High-resolution seismic reflection Profile 89 crossing Site 612 in strike direction. Shows erosional channel into which Hole 612 was drilled. E. High-resolution seismic reflection Profile 69 crossing Site 612 in a dip direction showing erosional channel seen in Figure $1 \mathrm{D}$. 

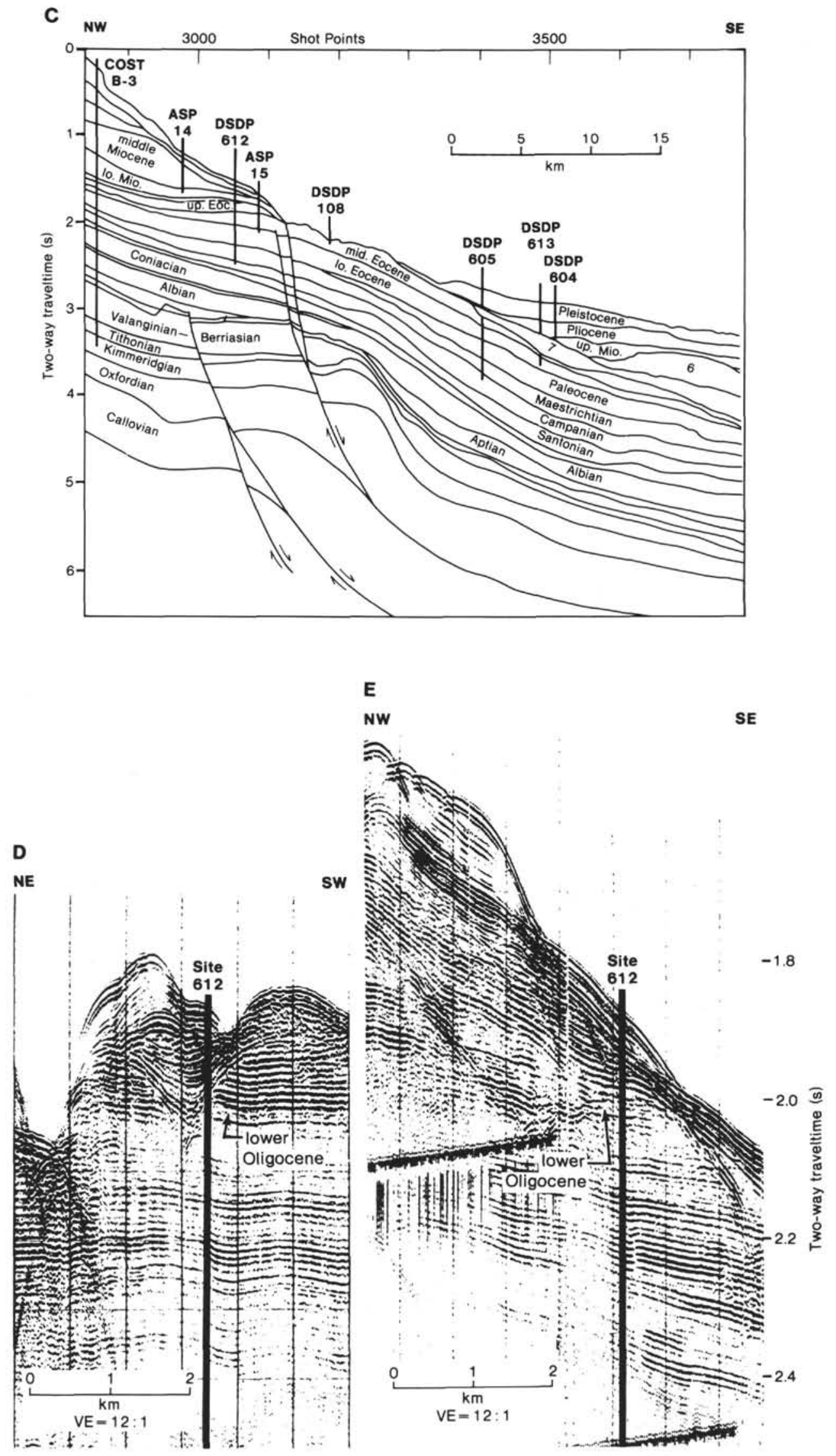

Figure 1 (continued). 


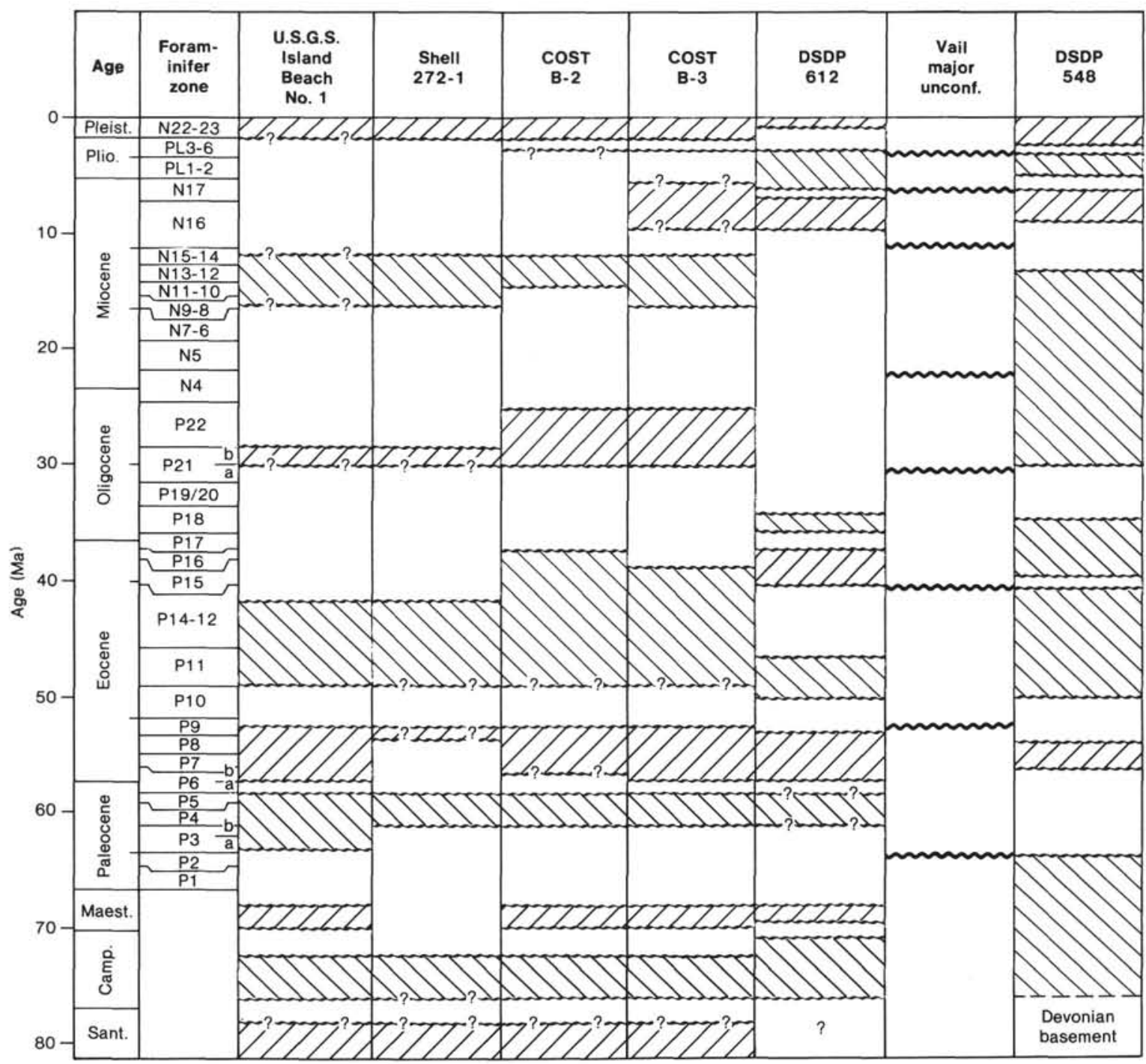

Figure 2. Chart showing relationships of global unconformities (wiggly horizontal lines) of the Vail depositional model to depositional sequences and stratigraphic gaps of the New Jersey continental shelf and slope and the continental slope of Ireland (DSDP 548). Data from Poag (1985a), Poag et al. (1985), and Poag and Low (1985). Blanks in stratigraphic columns represent hiatuses.

their associated disturbed zones. We attempted to maintain a $3-\mathrm{cm}$ interval between each $20-\mathrm{cm}^{3}$ sample, and to take seven samples above and seven below each contact. High-density sampling for other studies, however, prevented strict adherence to this plan. We also sampled as close to the contact (above and below) as possible. Microfossil samples were prepared by disaggregation in a warm Calgon solution (a commercial water softener), wet sieving on a $74-\mu \mathrm{m}$ screen, and oven drying at $70^{\circ} \mathrm{F}$.

A census of benthic foraminiferal assemblages was carried out on approximately 300 specimens per sample, derived from aliquots of the $>74-\mu \mathrm{m}$ size fraction, to determine the relative abundance of genera and species (Tables 1-6). The results may be compared with those of Miller and Katz (this volume) and Katz and Miller (this volume), who analyzed the $>150-\mu \mathrm{m}$ size fraction in some of the same core sections. We find that an assessment of the original community structure is more accurate when the small species (which are often predominant) are included in analyses (see also Scott, this volume). In many cases, those specimens that dominate the coarse sieve fractions are actually only a small portion (numbers of individuals) of the total assemblage. Sedimentological composition of the $>74 \mu \mathrm{m}$ fraction was also noted, and provides complementary information to shipboard interpretations.

We also examined the planktonic foraminiferal assemblages to refine the biozonations of Miller and Hart (this volume) and Hart (this volume), which were based on more widely spaced samples and coarser size fractions.

Our presentation proceeds chronostratigraphically from oldest to youngest levels in the cores, to emphasize the historical development of the New Jersey margin.

\section{CAMPANIAN/MAESTRICHTIAN CONTACT}

\section{Lithologic Characteristics}

The unconformable contact between Campanian and Maestrichtian strata is at approximately $8 \mathrm{~cm}$ in Section 612-69-3, where a concave scour surface separates dark gray to black, fissile, finely glauconitic, pyritic, laminated shale and chalk (below) from lighter gray, coarsely glauconitic (scattered, dark, distinctly larger grains) pyritic, marly, foraminiferal-nannofossil chalk (above) (Figs. 3, 4). Horizontal burrows, extending to at least 10 $\mathrm{cm}$ below the contact, are filled with the lighter gray, coarser, glauconitic sediment from above the contact. 


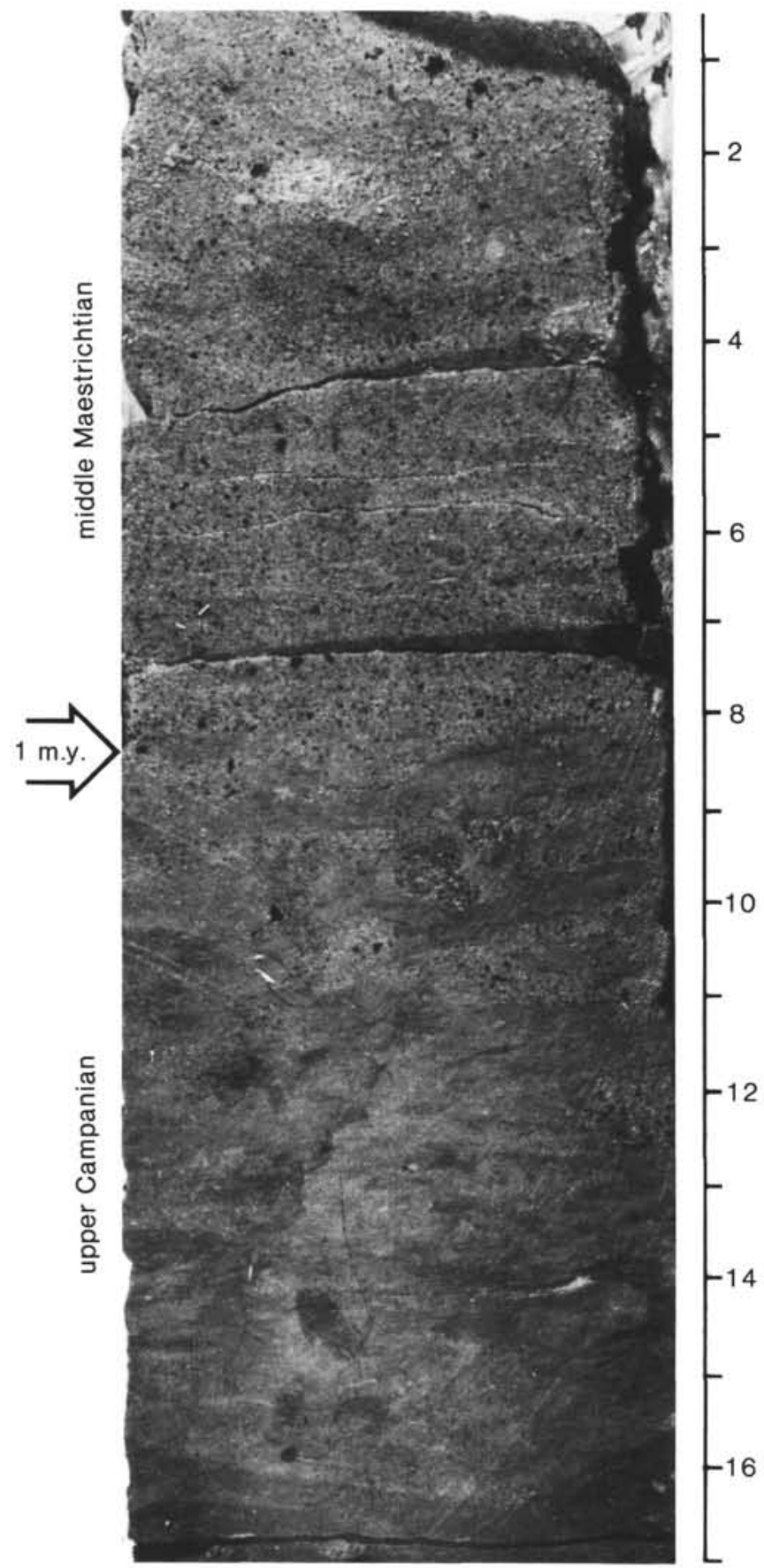

Figure 3. Photograph of the unconformable contact between the Campanian and Maestrichtian sequences at Site 612 (Section 612-69-3).

The $>74-\mu \mathrm{m}$ sieved residues of samples between 53 and $18 \mathrm{~cm}$ are planktonic foraminiferal oozes, containing small amounts of Inoceramus fragments, fish skeletal debris, ostracode valves, pyrite, and glauconite. Several indurated burrow casts in Sample 612-69-3, 15-18 $\mathrm{cm}$ contain glauconite in abundance; this was apparently derived from above the contact, as glauconite is rare elsewhere in the residue.

A marked lithologic change just below the unconformity $(612-69-3,10-14 \mathrm{~cm})$, is manifested by intense pyritization: euhedral aggregates as long as $2 \mathrm{~cm}$ are present along with many indurated burrow casts, large fragments (not prisms) of Inoceramus, benthic foraminifers, ostracodes, fish skeletal debris, and glauconite grains.
Just above the unconformable contact (Sample 61269-3, 4-7 cm), the sediment also is indurated, but in this interval the cementing agent is calcite. The sample did not completely disaggregate, and microfossils, although abundant, are secondarily calcified. Glauconite grains also are abundant.

The uppermost sample examined (Sample 612-69-2, $127-131 \mathrm{~cm}$ ) disaggregated completely, yielding an assemblage of abundant planktonic foraminifers, but they are poorly preserved because of secondary calcification. Glauconite is common, and burrow casts are filled with euhedral pyrite. A few Inoceramus prisms, ostracodes, and fragments of fish skeletons also are present.

\section{Biochronology}

The Campanian planktonic foraminiferal assemblage immediately below the unconformity (Sample 612-69-3, $10-14 \mathrm{~cm}$ ) is abundant and diverse, containing, among other species, Rosita fornicata, R. patelliformis, Globotruncanita stuartiformis, Globotruncana ventricosa, $G$. orientalis, G. linneiana, G. arca, Archaeoglobigerina cretacea, and Globigerinelloides multispina. Many of these taxa span the upper Campanian and lower Maestrichtian elsewhere; others are restricted to the Maestrichtian in indigenous assemblages, and have been brought downward as burrow fill. However, the presence of Kyphopyxa christneri, a typical Campanian form for this region (Poag, 1980), along with the absence of several diagnostic Maestrichtian species that are present above the contact, defines the age of this sample as Campanian.

Just above the unconformity (Sample 612-69-3, 4-7 $\mathrm{cm}$ ), the foraminiferal assemblage is small, containing poorly preserved specimens of many of the same planktonic species noted below the unconformity. The presence of Kyphopyxa christneri and a specimen of Marginotruncana sp. indicates redeposition of older forms. Specimens of Gansserina gansseri appear to be indigenous, however, indicating a middle Maestrichtian age for this sample. A hiatus estimated to be at least $1 \mathrm{~m} . \mathrm{y}$. is represented by the unconformity.

The highest sample examined in the Cretaceous section (Sample 612-69-1, 120-124 cm) is also of middle Maestrichtian age, but contains a more complete and well-preserved suite of planktonic foraminifers, including Rosita contusa, Globotruncanella havanensis, G. petaloidea, and Globotruncana aegyptiaca.

\section{Geophysical Characteristics}

The Campanian/Maestrichtian contact is marked by significant shifts in both the sonic (interval transit time) and gamma-ray curves recorded by downhole logging (Fig. 5). The higher gamma-ray values in the Campanian section reflect a larger component of terrigenous clay as compared with the Maestrichtian section. Sonic velocities (reciprocal of interval transit time), on the other hand, are greater in the Maestrichtian section. The major inflection of the sonic log at $2.57 \mathrm{~s}$ corresponds to a strong seismic reflector at this position on Line 25 . The reflector can be traced updip to the shelf, and downdip to the rise, although its amplitude is diminished beneath the middle Eocene submarine outcrop belt (Fig. 6). 


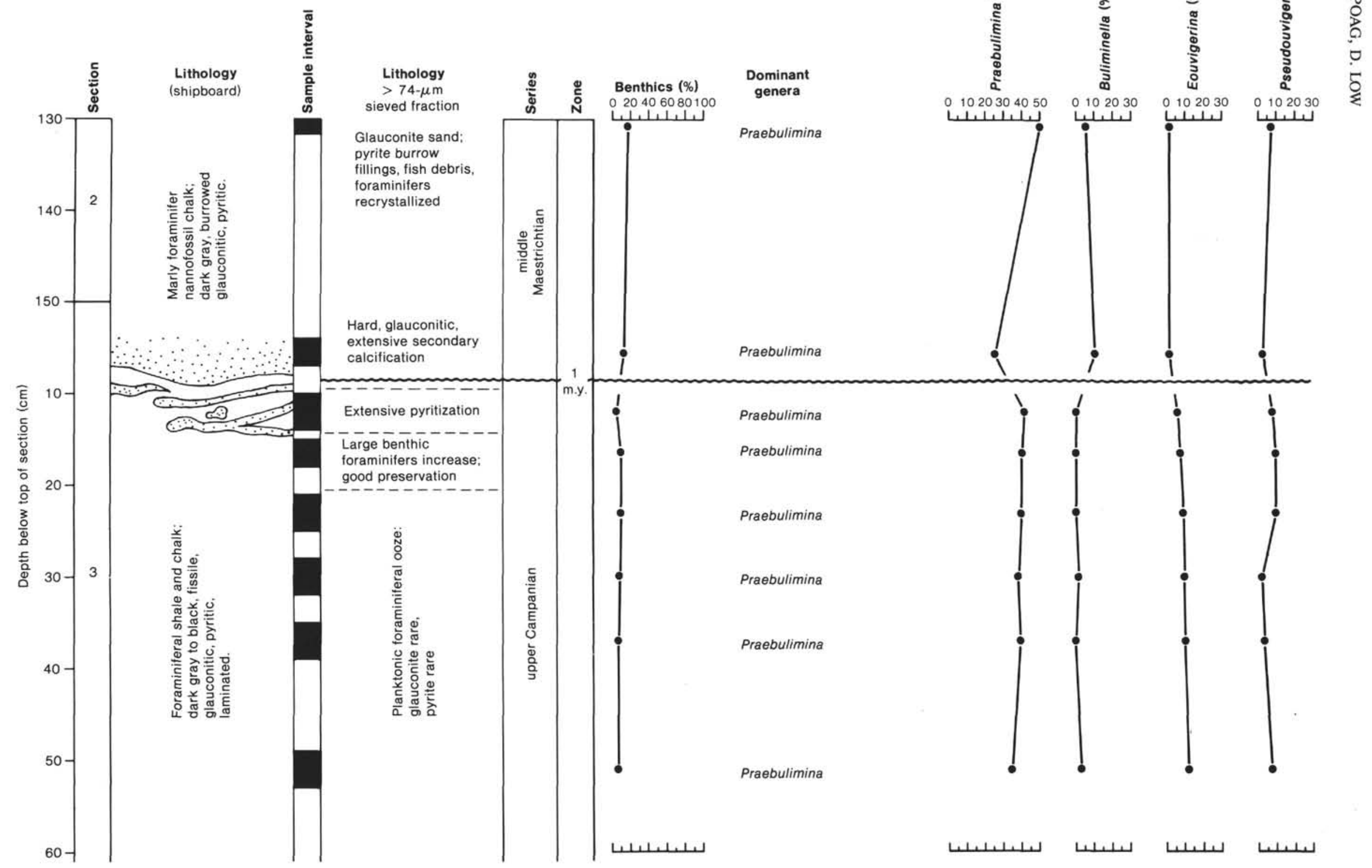

Figure 4. Chart showing lithic and benthic foraminiferal characteristics across the Campanian/Maestrichtian contact at Site 612 . Sample intervals indicated by heavy black rectangles in column 4 . Biochronology based mainly on planktonic foraminifers, supplemented by nannofossils. Length of hiatus represented by unconformity is indicated at the contact, within the column labeled "zone." 


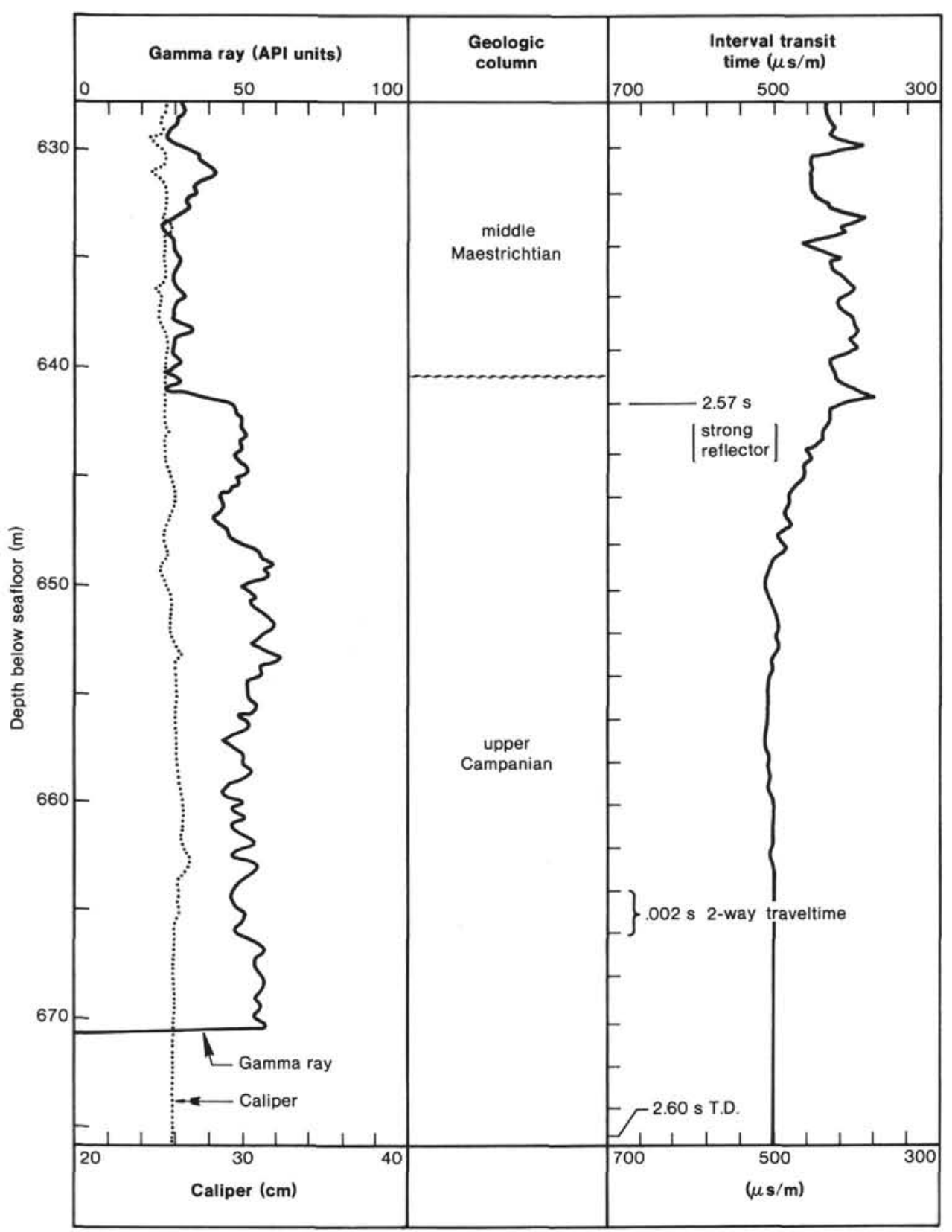

Figure 5. Downhole logging characteristics across the Campanian/Maestrichtian contact at Site 612 .

\section{Benthic Foraminiferal Characteristics}

The benthic foraminiferal assemblages undergo moderate change across the Campanian/Maestrichtian contact (Fig. 4; Table 1). The percentage of benthic foraminifers increases from 5-9\% below the contact to $11-13 \%$ above. Praebulimina dominates every sample, ranging from 36 to $42 \%$ below the contact and from 27.5 to $48.7 \%$ above. The lowest value $(2.8 \%)$ is associated with the indurated layer just above the contact. At the same place, Buliminella increases from 0 to $1.2 \%$ (below) to 4.5 to $11.9 \%$ (above), and the highest value for this genus is immediately above the contact. A reciprocal trend is present in Eouvigerina and Pseudouvigerina, whose values decrease from 7.1 to $12.4 \%$ and 2.8 to $10.6 \%$ respectively, below the contact, to 0.9 to $1.3 \%$ and 3.2 to
$6.5 \%$ above. The number of benthic genera remains nearly constant below; (22-29 below; 21-27 above). Additional samples in the Maestrichtian interval are needed to corroborate these observations.

\section{Interpretation}

The depositional patterns revealed by seismic Line 25 and adjacent lines (Poag, 1985a) show a gently sloping, relatively thin Campanian section crossing the present New Jersey shelf, slope, and rise, to about shotpoint 3100 (Fig. 7). Seaward of this position, the Campanian/ Maestrichtian contact dips more steeply into the North American basin, and the Campanian section thickens significantly in a short distance, forming a prograded, downlapping, slope-front prism. The inflection point where this prism begins to thicken rapidly marks the shelf break 


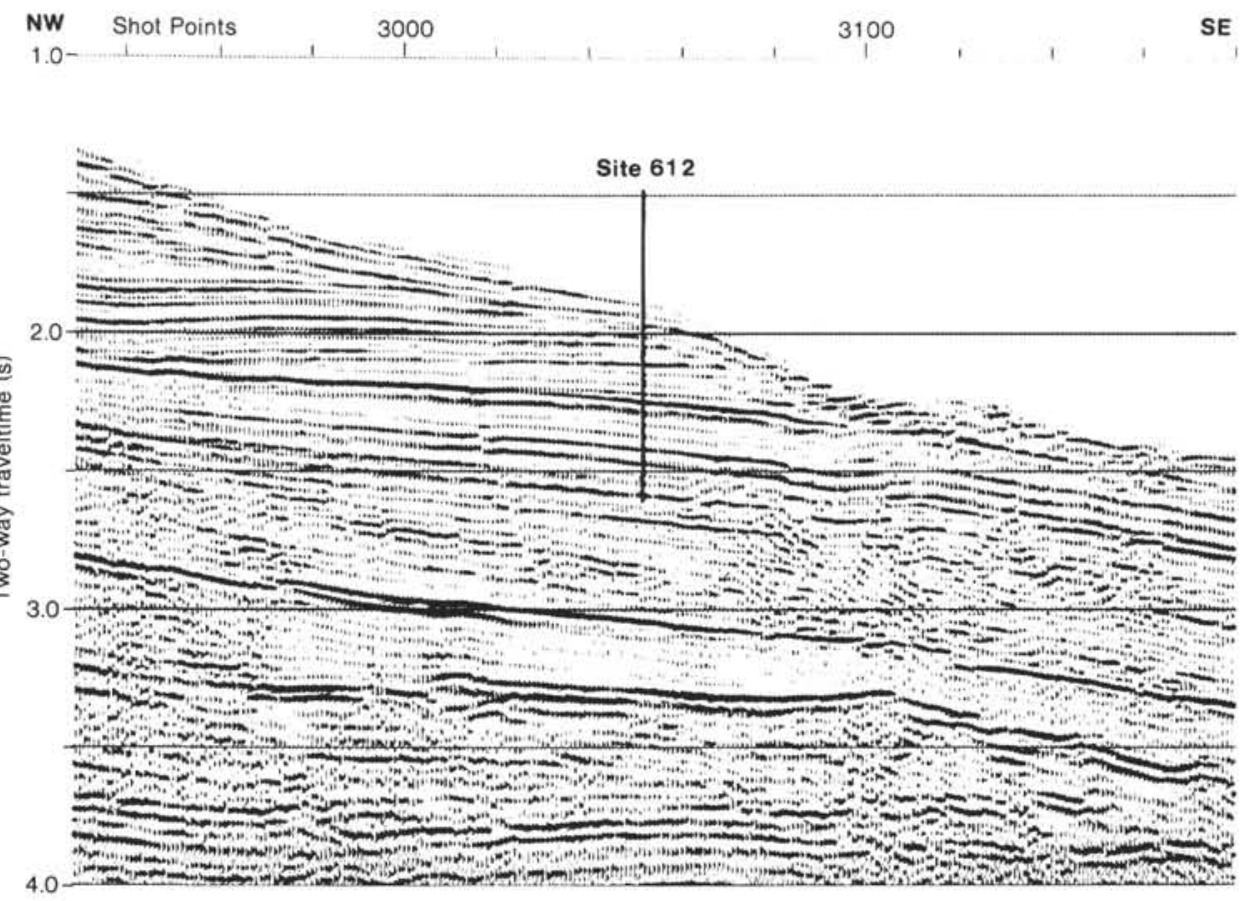

Figure 6. Seismic expression of stratigraphic sequences on Line 25 in the vicinity of Site 612.

approximately at the end of Campanian time. Site 612, located $8 \mathrm{~km}$ updip from shotpoint 3100 , occupied, therefore, the outer edge of the continental shelf as Campanian deposits accumulated.

By analogy with modern distribution patterns, the benthic foraminiferal association, dominated by Praebuliminia, Eouvigerina, Gyroidina, and Gavelinella (Table 1 ), in conjunction with great benthic generic richness and high planktonic percentage, suggests bathyal depths (300$500 \mathrm{~m}$ at Site 612 during the Campanian). Poag (1980, 1985a) estimated somewhat shallower depths (150-200 m) for the COST B-3 well, which is $10 \mathrm{~km}$ updip. Sliter and Baker (1972) designed a Cretaceous paleobathymetric model (also using a modern analog) in which assemblages characterized by Praebuliminia, Gavelinella, Gyroidinoides, and Osangularia were interpreted to have accumulated on the continental slope in depths of 500 to $800 \mathrm{~m}$. The modern analog used by Sliter and Baker is the eastern Pacific margin.

If one applies a paleoslope model like that of Olsson and Nyong (1984) and Nyong and Olsson (1984) (which uses the modern seafloor slope of $\sim 1 \mathrm{~m} / \mathrm{km}$ off New Jersey, and estimates a paleodepth of $50-100 \mathrm{~m}$ at the New Jersey outcrop), shotpoint 3100 (on Line 25) would have been covered by a water column $300-400 \mathrm{~m}$ deep, and the shoreline would have been approximately $50 \mathrm{~km}$ inland of the present outcrop (yielding a shelf $280 \mathrm{~km}$ wide; Fig. 8).

Thus, each of these analytical methods predicts that the Campanian/Maestrichtian assemblages of Site 612 were deposited in upper to middle bathyal depths (300$800 \mathrm{~m}$ ), even though physiographically it was an outer shelf location. This contrast with the modern shelf-break depth of $\sim 200 \mathrm{~m}$ is not surprising in view of the general consensus that sea levels of the Campanian and Maes- trichtian were among the highest in the history of the Atlantic Ocean (e.g., Vail et al., 1977; Pitman, 1978; Watts and Steckler, 1979; Hancock and Kauffman, 1979; Watts and Thorne, 1984; Harris et al., 1984; Seiglie and Baker, 1984).

Prior to the erosion that created the unconformable Campanian/Maestrichtian contact, Site 612, on the outer part of a shelf twice as wide as today's, received chiefly clay-sized terrigenous detritus and a rain of pelagic carbonate. An abundance of burrows indicates that bottom waters were well aerated. However, interstitial waters in the section just below the contact must have been deficient in oxygen as evidenced by the unusual enrichment in pyrite.

A sea-level drop of $100 \mathrm{~m}$ would have been sufficient to bring the shoreline to near its present position, assuming no change in the rate of basin subsidence. However, isostatic adjustment resulting from the removal of the water column and erosion of the sedimentary column may have pushed the shoreline even closer to Site 612.

Following the erosion, deposition resumed on the outer part of a wide shelf. The shelf break marked by the top of the slope-front prism, shifted seaward about $10 \mathrm{~km}$ during the Maestrichtian to shotpoint 3300 (on Line 25; Fig. 7). Principal sedimentary components were pelagic carbonate particles; the amount of clay was reduced compared to that in the section below the unconformity. Glauconite accumulated as thinly scattered large grains. Foraminiferal constituents remain nearly the same across the contact, suggesting little change in paleodepth or bottom-water composition between the late Campanian and early Maestrichtian. However, interstitial waters contemporaneous with the early Maestrichtian sedimentation must have been considerably different than before 
Table 1. Census of benthic foraminiferal genera ( $\%$ of total benthic assemblage $>74 \mu \mathrm{m}$ ).

\begin{tabular}{|c|c|c|c|c|c|c|c|c|}
\hline \multirow[b]{3}{*}{ Genus } & \multicolumn{8}{|c|}{ Sample interval in $\mathrm{cm}$} \\
\hline & \multirow{2}{*}{$\frac{612-69-2}{127-131}$} & \multicolumn{7}{|c|}{$612-69-3$} \\
\hline & & $4-7$ & $10-14$ & $15-18$ & $21-25$ & $28-32$ & $35-39$ & $49-53$ \\
\hline Buliminella & 4.5 & 11.9 & 1.0 & 0.5 & $-{ }^{a}$ & 1.0 & - & 1.2 \\
\hline Eouvigerina & 1.3 & 0.9 & 7.1 & 7.5 & 8.4 & 10.8 & 11.2 & 12.4 \\
\hline Gavelinella & 1.3 & 8.7 & 9.4 & 10.1 & 11.7 & 5.6 & 7.5 & 12.2 \\
\hline Gyroidina & 10.7 & 10.4 & 9.9 & 7.0 & 6.0 & 7.7 & 4.4 & 5.0 \\
\hline Praebulimina & 48.7 & 27.5 & 42.0 & 38.9 & 40.3 & 38.5 & 39.1 & 36.0 \\
\hline Pseudouvigerina & 6.5 & 3.2 & 8.9 & 10.6 & 10.4 & 2.8 & 2.7 & 7.4 \\
\hline Allomorphina & - & - & 0.5 & 0.3 & - & 0.3 & 0.3 & - \\
\hline Ammobaculites & - & - & - & 0.3 & - & 0.3 & - & - \\
\hline Anomalina & - & - & 0.3 & - & - & 1.4 & - & - \\
\hline Arenobulimina & - & 0.3 & - & - & - & - & - & - \\
\hline Bolivina & - & 4.6 & - & 2.8 & 1.0 & 0.3 & 0.7 & - \\
\hline Bolivinoides & 3.6 & 5.5 & - & 0.8 & 1.0 & - & - & 0.2 \\
\hline Bulimina & 0.6 & - & - & - & - & - & - & - \\
\hline Charltonina & 3.9 & 1.7 & 3.8 & 1.5 & 4.4 & 4.5 & 3.7 & 2.0 \\
\hline Chilastomella & - & 0.3 & - & - & - & - & - & - \\
\hline Cibicides & 2.6 & 7.0 & - & - & - & - & - & 0.5 \\
\hline Dentalina & 0.6 & 0.6 & 1.3 & 1.5 & 2.0 & 0 & 1.0 & 1.7 \\
\hline Dorothia & - & - & - & 0.5 & - & - & 0.3 & 0.2 \\
\hline Eponides & - & - & 0.3 & - & - & 1.7 & 6.1 & 3.2 \\
\hline Fissurina & 1.6 & 0.3 & - & 1.0 & 0.7 & 0.3 & - & - \\
\hline Frondicularia & - & - & 0.3 & - & - & - & - & - \\
\hline Gaudryina & - & 2.0 & 2.0 & - & - & - & - & - \\
\hline Globorotalites & - & - & - & - & - & - & 0.7 & 1.2 \\
\hline Haplophragmoides & - & - & - & 0.3 & - & - & - & - \\
\hline Heronallenia & - & - & - & 0.3 & - & - & - & - \\
\hline Heterostomella & - & - & 0.5 & 1.0 & - & - & - & - \\
\hline Lagena & 1.3 & - & 1.0 & - & 0.7 & 1.4 & 1.4 & - \\
\hline Lenticulina & 1.0 & 0.3 & - & 0.8 & - & 0.3 & 0.7 & 0.7 \\
\hline Laxostomum & 4.9 & 0.6 & - & 0.3 & - & 2.8 & 3.4 & 3.5 \\
\hline Marginulina & - & - & - & - & 0.3 & - & - & - \\
\hline Nodosaria & - & 0.6 & 0.8 & -0 & - & - & 0.3 & - \\
\hline Nonion & - & - & - & 0.8 & 1.3 & - & - & - \\
\hline Nonionella & 1.0 & - & - & - & - & - & - & - \\
\hline Osangularia & - & 3.8 & - & - & - & - & 0.3 & - \\
\hline Planulina & - & - & - & 0.8 & - & 1.4 & 0.3 & 0.2 \\
\hline Pleurostomella & 1.0 & - & - & - & - & - & - & 0.3 \\
\hline Polymorphina & - & - & 0.5 & - & - & - & - & - \\
\hline Puillenia & - & - & 1.0 & 2.0 & - & 5.6 & 2.0 & 0.5 \\
\hline Pyramidina & 0.3 & 2.0 & - & - & 1.0 & - & - & 1.5 \\
\hline Quadrimorphina & 0.6 & - & - & - & 0.7 & - & 0.7 & 0.7 \\
\hline Quinqueloculina & - & - & - & 0.3 & - & - & - & - \\
\hline Reussella & - & 1.7 & 1.0 & 1.5 & 1.0 & 1.0 & 0.7 & 0.7 \\
\hline Saccammina & - & - & - & - & - & 0.7 & - & - \\
\hline Spiroloculina & - & - & 0.5 & - & 0.3 & - & 0.3 & - \\
\hline Spiroplectammina & 1.6 & 1.2 & 0.3 & - & 0.7 & 0 & 0.3 & 0.5 \\
\hline Stensioina & - & 0.9 & - & - & - & - & 0.3 & - \\
\hline Stilostomella & 2.3 & - & 1.3 & 1.8 & 3.4 & - & 0.7 & 0.7 \\
\hline Textularia & - & 0.9 & - & - & - & - & - & - \\
\hline Tritaxia & - & 0.3 & 0.5 & 0.8 & 2.0 & 2.8 & 0.7 & 3.0 \\
\hline Turrilina & - & 1.2 & - & - & - & - & - & - \\
\hline Valvulineria & - & - & 0.3 & 1.0 & 1.7 & 2.8 & 3.7 & 1.0 \\
\hline$" X "$ & - & 1.7 & 2.0 & 5.5 & 1.0 & 5.6 & 4.1 & 2.7 \\
\hline Total specimens & 308 & 345 & 393 & 398 & 298 & 286 & 294 & 403 \\
\hline$\%$ Benthics & 11 & 13 & 5 & 9 & 7 & 7 & 6 & 9 \\
\hline No. of benthic genera & 21 & 27 & 29 & 28 & 22 & 23 & 29 & 26 \\
\hline
\end{tabular}

a - means not present.

the erosion, causing notable dissolution and reprecipitation of calcite, which cemented the strata just above the contact.

\section{Regional Relationships}

The Campanian/Maestrichtian unconformity can be traced widely on seismic reflection profiles beneath the shelf, slope, and rise of the middle Atlantic margin of the U.S., and the unconformity has been documented on the shelf and upper slope in the COST B-2 and COST B-3 wells and at the shoreline in the U.S.G.S. Island Beach No. 1 well (Poag, 1985a). On the coastal plain, it has been recorded by Owens and Gohn (1985) and, indirectly, by Olsson and Nyong (1984). This unconformity falls within the upper part of supercycle $\mathrm{Kb}$ of the Vail model (Vail and Mitchum, 1979; Fig. 9), an interval whose details have not been published by Vail and his colleagues. It is a persistent phenomenon, however, on the U.S. Atlantic margin (Poag and Schlee, 1984). Elsewhere, it has been documented in the western interior of the U.S. (Weimer, 1984) and from central West Africa (Seiglie and Baker, 1984). Ziegler (1982) indicates that this unconformity is globally distributed.

\section{LOWER EOCENE (Ypresian)/MIDDLE EOCENE (Lutetian) CONTACT}

\section{Lithologic Characteristics}

The contact between the Ypresian and Lutetian stages at Site 612 is more complex than the Campanian/ Maestrichtian contact. Instead of a sharply defined scour surface, burrowing across the contact has mixed two biosiliceous chalk units (Fig. 10). Below the contact (which is at $\sim 81 \mathrm{~cm}$ in Core 612-37-3), the dominant lithology is dark, yellowish brown chalk. It is penetrated by numerous horizontal burrows filled with light greenish gray, coarsely glauconitic chalk derived from above the contact. The lighter chalk above the contact is thinly laminated, frequently burrowed, and contains occasional layers of glauconite, as well as scattered coarser grains of glauconite. In addition, there are hard clasts of redeposited, dark gray, Upper Cretaceous chalk at several places in the light gray unit (see discussion below), indicating that this is part of a debris flow deposit. A 3-cm-long clast of Cretaceous age may be seen in Figure 10, between 78 and $75 \mathrm{~cm}$; another was sampled at $40-36 \mathrm{~cm}$ (Fig. 11).

In the $>74-\mu \mathrm{m}$ sieved fraction, the lithology below the unconformity is varied. The lower two samples (612$37-3,132-135 \mathrm{~cm}$ and $126-128 \mathrm{~cm}$ ) contain hard fragments of tan and white chalk that did not disaggregate completely during preparation. These fragments have a vuggy surface texture caused by hollow impressions of foraminiferal tests. The free foraminiferal specimens are poorly to moderately preserved. Fish skeletal debris is also a common component of this residue.

Sample $612-37-3,120-124 \mathrm{~cm}$, contained a well-preserved planktonic foraminiferal ooze that easily disaggregated. The dominant lithology in the next two samples $(612-37-3,105-114 \mathrm{~cm})$ is tan porcellanitic chalk. The sediment hardly disaggregated at all and the few foraminiferal specimens released are barely recognizable as foraminifers.

Between $612-37-3,100 \mathrm{~cm}$ and the unconformity $(\sim 81$ $\mathrm{cm}$ ), all three samples disaggregated completely, yielding a well-preserved planktonic foraminiferal ooze. Additional elements of the residue include echinoid spines, fish skeletal debris, glauconite grains, and euhedral pyrite.

The section above the unconformity is even more variable than that below (Fig. 11). The first sample (612-37$3,75-79 \mathrm{~cm}$ ) was taken from the hard Upper Cretaceous intraclast, composed of tan chalk that resisted disaggregation. Preservation of planktonic foraminifers is poor, although numerous hollow impressions of them create vuggy surfaces on the chalk fragments.

Softer sediment in the three samples from Section $612-37-3,43$ to $61 \mathrm{~cm}$ disaggregated completely, leaving an excellently preserved planktonic foraminiferal ooze, along with echinoid spines, fish skeletal debris, glauconite grains, and euhedral pyrite. 


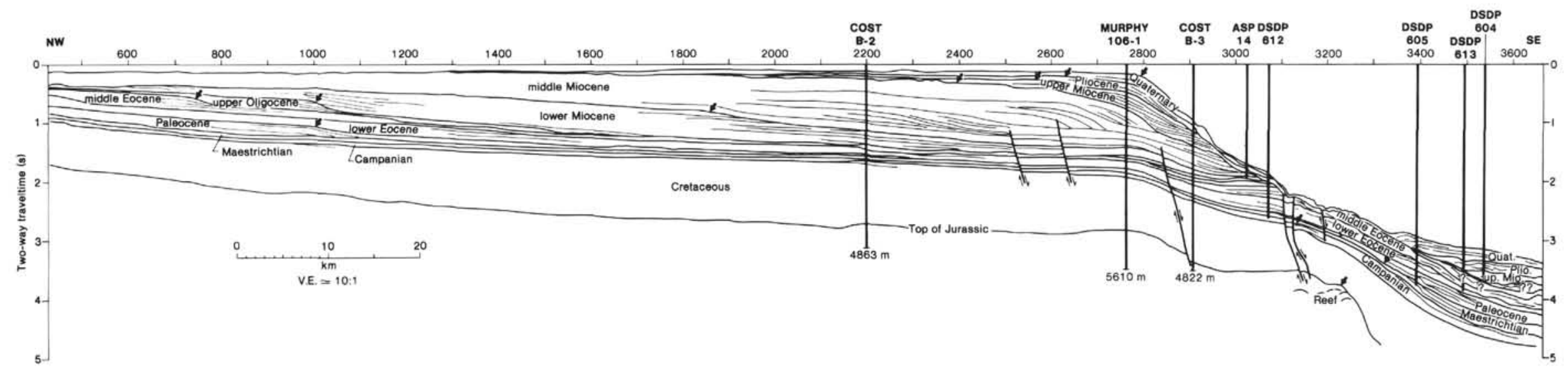

Figure 7. Interpretation of stratigraphy and ancient shelf break positions along Line 25 . Arrows point to positions of successive shelf breaks. Note that most shelf breaks have been modified by subsequent erosion (truncated reflections). 


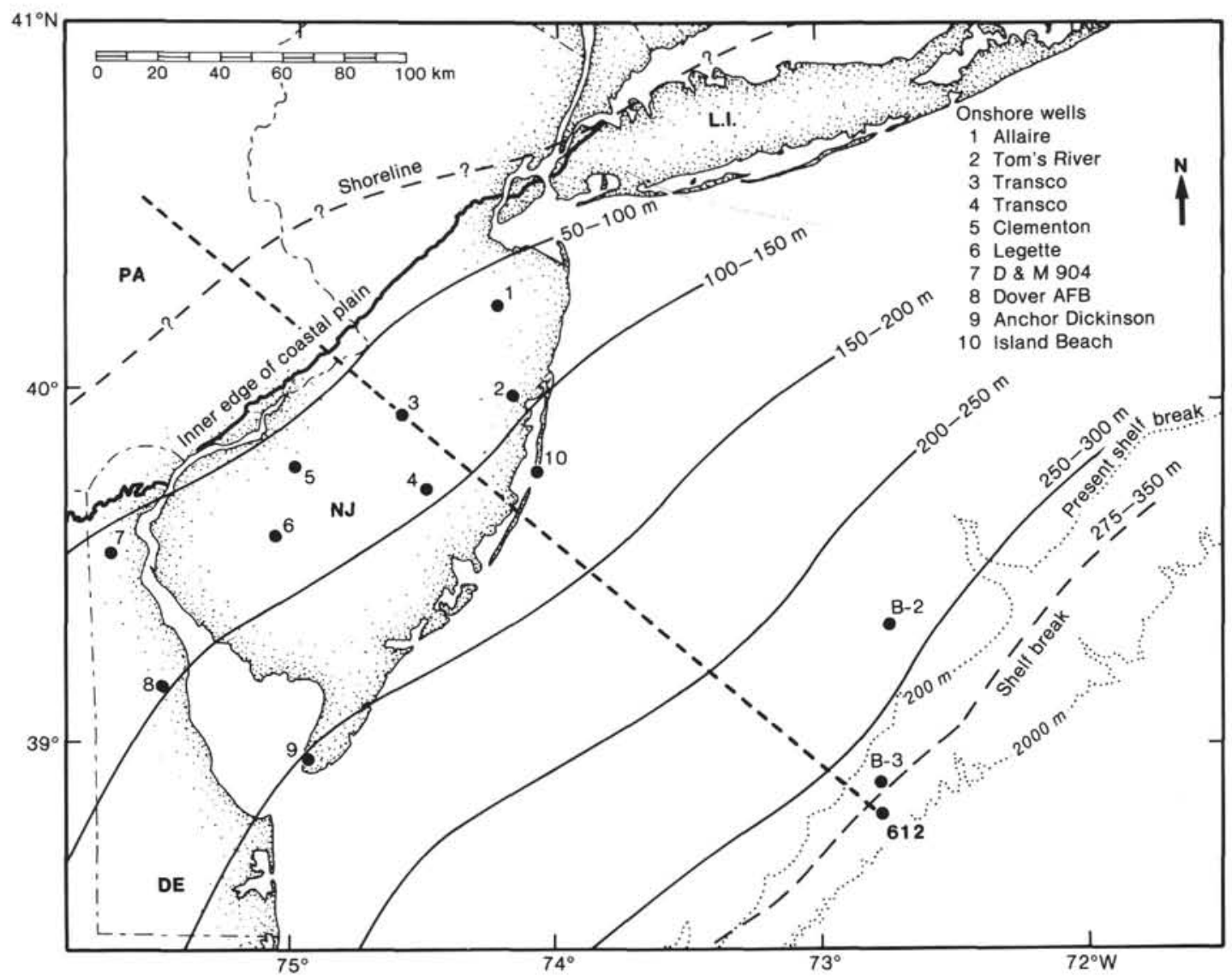

Figure 8. Generalized late Campanian seafloor morphology based on a paleoslope model. Onshore data from Olsson and Nyong (1984).

Sample 612-37-3, 36-40 $\mathrm{cm}$ also disaggregated, but the resultant planktonic foraminiferal ooze is entirely of Late Cretaceous age, indicating derivation from a redeposited clast. Along with the excellently preserved foraminifers, are echinoid spines, fish skeletal debris, mica flakes, and euhedral pyrite.

Another soft sediment sample $(612-37-3,28-31 \mathrm{~cm})$ contained white chalk, which disaggregated almost completely, yielding a moderately-well-preserved planktonic foraminiferal ooze of middle Eocene age (see below). This residue includes echinoid spines, fish skeletal debris, a few ostracodes, some glauconite grains, and euhedral pyrite. The youngest sample examined (612-37-3, $16-20 \mathrm{~cm}$ ) was another firm white chalk that only partly disaggregated, yielding large chalky chips and a few grains of glauconite and quartz. The surfaces of the chips are vuggy where planktonic foraminifers were imbedded. A few free specimens of radiolarians and planktonic foraminifers are present, but poorly preserved, accompanied by fish skeletal debris and fragments of calcitic vein fillings.

\section{Biochronology}

A sample below the unconformity at Sample 612-373, 196-100 cm contains a well preserved in situ assemblage of lower Eocene (Ypresian) planktonic foramini- fers, including Morozovella caucasica, M. aragonensis, Acarinina matthewsae, A. broedermanni, A. pentacamerata, Subbotina crociaperta, and Muricoglobigerina senni, which indicate Zone P9 (Blow, 1979). A few specimens of redeposited Upper Cretaceous planktonic species are also present here. A similar association of in situ and redeposited forms is present in the other samples below the unconformity.

In Sample 612-37-3, 58-61 cm, above the unconformity, the planktonic foraminiferal assemblage contains Morozovella aragonensis, S. frontosa, and Muricoglobigerina soldadoensis; at $43-46 \mathrm{~cm}$ and $28-31 \mathrm{~cm}$, there are, in addition, Globigerinoides(?) higginsi, Acarinina bullbrooki, and Truncorotaloides quetra. These assemblages indicate that the indigenous taxa represent zones P10-P11 of the middle Eocene (Lutetian; Blow, 1979), but that specimens from Zone P8 or older ( $T$. quetra; lower Eocene) have been incorporated by redeposition. The length of the hiatus represented by the unconformity can not be directly determined from the foraminifers because only part of a zone (undetermined amount) is missing (this is also true for the nannofossil record; Fig. 11; see Valentine, this volume). Miller and Katz (this volume) use the change in sedimentation rate at this contact to estimate a 1 to $5 \mathrm{~m}$.y. hiatus (most of hiatus appears to represent basal Zone P10). However, the nan- 


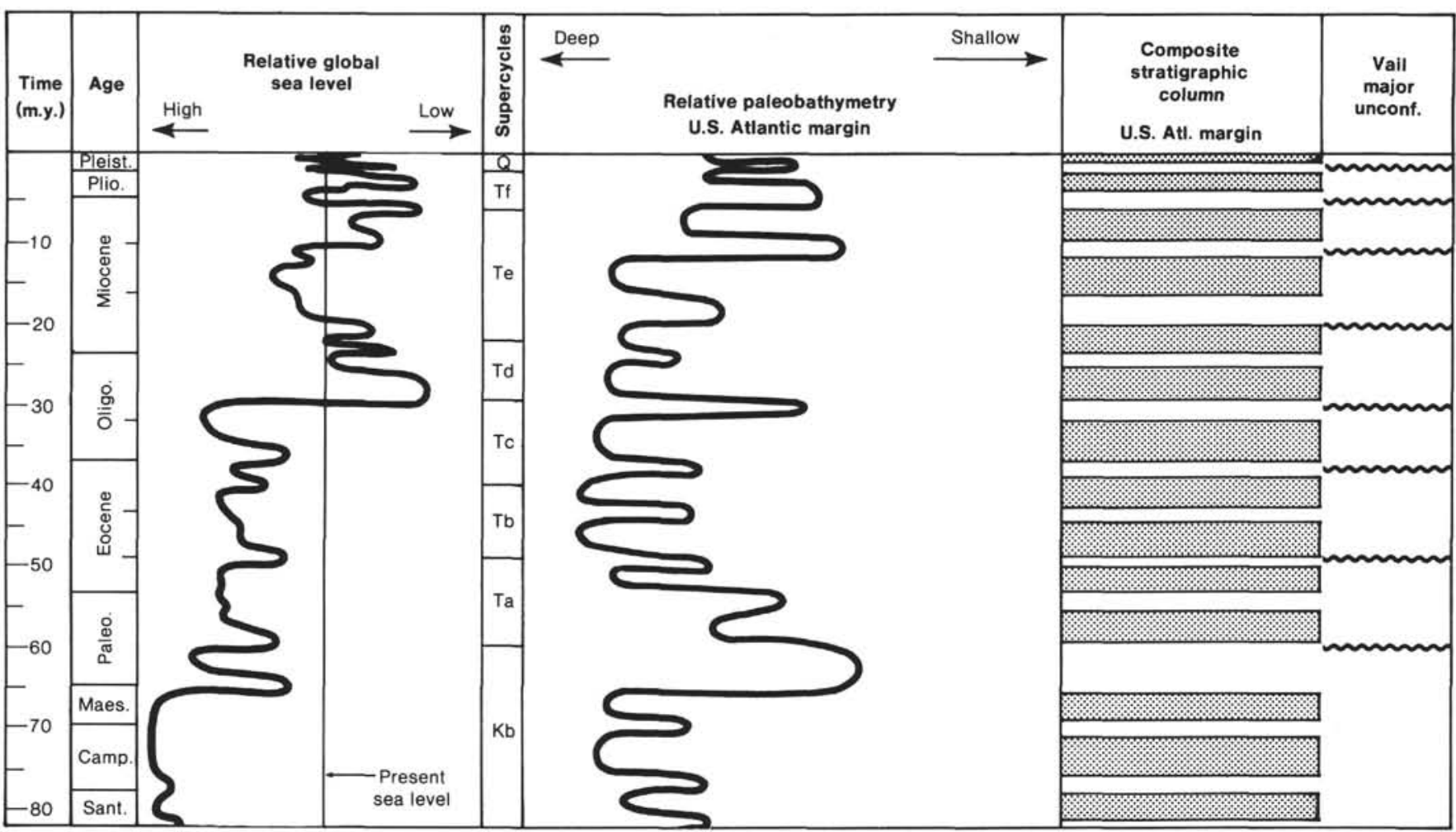

Figure 9. Sea-level curve, supercycles, and global unconformities of the Vail depositional model. Data from Vail and Hardenbol (1979), Vail and Mitchum (1979), and Poag and Schlee (1984).

nofossil Zone CP12b, which encompasses the unconformity, is only $2 \mathrm{~m}$.y. in total length (Berggren et al., 1985), so the hiatus must be less than 2 m.y.

\section{Geophysical Characteristics}

The sonic log records a sharp upward increase in velocity at the Ypresian/Lutetian contact (Fig. 12; at $2.26 \mathrm{~s}$ on the integrated sonic log). It correlates with a strong seismic reflector at this depth on Line 25 (Fig. 6). An upward velocity decrease at $2.25 \mathrm{~s}$ is associated with the top of a zone of silica diagenesis (porcellanite "front"). The impedance contrast causing the high-amplitude seismic reflector on Line 25 is probably a result of the close proximity of the diagenetic front and the unconformity.

The gamma-ray log also indicates a significant decrease in clay content above the unconformity, as the curve deflects from consistently higher values below the contact to lower values above.

\section{Benthic Foraminiferal Characteristics}

Distinctive changes in the benthic foraminiferal assemblages across the Ypresian/Lutetian contact are expressed most clearly by the upward reductions of Bulimina and Turrilina at the contact. Below the contact, Bulimina is predominant or co-predominant in seven of eight samples (Fig. 11; Table 2). Above the contact, $\mathrm{Bu}$ limina is consistently less than $10.5 \%$ (range $=3.8$ to $10.2 \%$; mean $=5.9 \%$ ) and is no longer predominant. Turrilina is predominant or co-predominant in three samples below the contact (range $=10.8$ to $40 \%$; mean $=$ $24.4 \%$ ), declines upward from a peak in Sample 612-37-
$3,111-114 \mathrm{~cm}$, to $10.9 \%$ just below the contact, and essentially disappears above it (present in 3 samples, ranging from 1.9 to $3.5 \%$ ). Nuttallides, on the other hand, increases above the contact ( 1.6 to $4.1 \%$ below; 7.9 to $14.6 \%$ above).

Among the predominant genera of in situ samples above the contact are Stilostomella, Cibicides, Cassidulina, Tritaxia, Nuttallides, and Pullenia. Among the redeposited Cretaceous assemblages above the contact, Cibicides, and, especially, Praebulimina are predominant (Praebulimina $=49.8 \%$ in Sample 612-37-3, 36-40 cm). The Praebulimina values are similar to those in the Campanian-Maestrichtian section described above, from which the clast probably was derived. Benthic percentage varies little throughout the section.

In a separate study, Miller and Katz (this volume) also demonstrated a major change in the benthic foraminiferal assemblage across this contact, manifested by the abrupt appearance above it of 10 species.

\section{Interpretation}

Prior to erosion of the Ypresian-Lutetian unconformity, the lower Eocene seafloor at Site 612 was part of a wide, gently sloping carbonate ramp, on which no distinct shelf break has been identified (Fig. 7). The site received chiefly pelagic carbonate and biosiliceous sediment in a well-oxygenated, low-energy environment (abundant burrows of benthic invertebrates). However, updip sources of exposed Upper Cretaceous strata provided material for particulate redeposition within the lower Eocene chalks. By analogy with modern assemblages, 


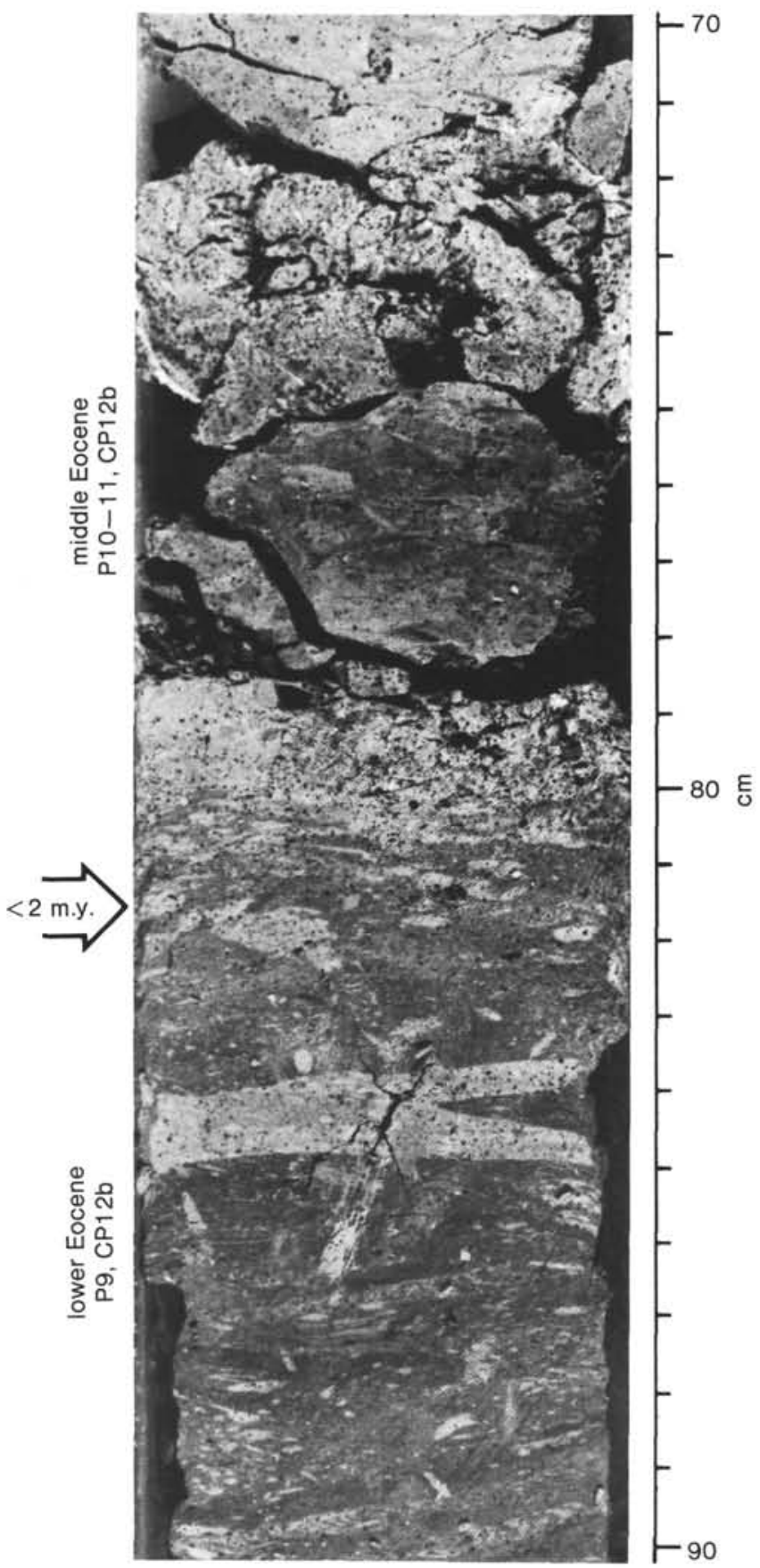

Figure 10. Photograph of the unconformable contact between the lower Eocene and middle Eocene sequences at Site 612 (Section 612-373).

the dominance of Bulimina, the composition of the associated benthic assemblage, and the low percentage of benthic species suggest that bathyal depths (500-1000 m) prevailed at this locality (Fig. 13). Poag (1980, 1985a) estimated (by similar modern analogy) that paleodepth at the nearby COST B-3 well was approximately $800-1200$ $\mathrm{m}$. Miller and Katz (this volume) estimate a paleodepth of around $1000 \mathrm{~m}$ for the entire Eocene at Site 612 on the basis of backtracking and backstripping techniques. Application of the Campanian paleoslope model yields much shallower paleodepths for Site 612. Charletta (1980) found that lower Eocene foraminiferal assemblages near the present outcrop in New Jersey could be assigned to a paleodepth of about 100-150 m (using a modern ana$\log$ ), only slightly deeper than late Campanian depths. If we assume a paleoslope of $1 \mathrm{~m} / \mathrm{km}$, the model predicts an early Eocene paleodepth at Site 612 of $\sim 300$ $350 \mathrm{~m}$. This estimate appears to be much too shallow, suggesting that the gradient of the early Eocene seafloor was greater than that of the Campanian (and modern) shelf.

Following the erosion that formed the lower Eocenemiddle Eocene unconformity, a debris-flow unit was emplaced, incorporating relatively large (3-4 $\mathrm{cm}$ diameter) clasts of Upper Cretaceous chalk into the middle Eocene matrix. Pelagic carbonate and biosilica then began to accumulate again in conditions similar to those of the early Eocene. However, the presence of occasional clasts of Upper Cretaceous chalk, and particulate debris from the lower Eocene section, attests to the continuing erosion of updip exposures and the periodic passing of debris flows and turbidites.

Sometime following deposition of these Eocene strata, diagenetic alteration took place, dissolving the siliceous microfossil tests in irregular zones within the lowest middle Eocene and highest lower Eocene beds. The resulting silica cement changed the pelagic carbonates into hard porcellanite, which provided poor samples for microfossil analysis.

\section{Regional Relationships}

The Ypresian/Lutetian contact is widely recognizable on seismic reflection profiles crossing the New Jersey margin and has been documented as far shoreward as the U.S.G.S. Island Beach No. 1 well (Poag, 1985a). Ward (1984) and Ward and Strickland (1985) also noted it as a widespread unconformity among outcropping formations of the coastal plain, from South Carolina to Maryland. It also crosses the sites of the COST B-2 and B-3 wells, where the accompanying silicification impairs foraminiferal preservation and obscures the biozonation (Poag, 1985a). The contact also was cored downdip at Sites 605 and 613, and can be traced on seismic profiles well seaward under the continental rise (Poag, 1985b). Popenoe (1985) also recorded this unconformity on the continental slope of Georgia, where it is exhibited on seismic reflection profiles as an erosional swath cut by the paleo-Gulf Stream.

Thorne and Watts (1984) suggested that the seismic reflector associated with this contact at Site $612 \mathrm{might}$ be solely caused by the porcellanite and thus could be a diachronous reflector. However, at both Sites 612 and 613 , the porcellanite front is too close to the unconformity $(2-8 \mathrm{~m})$ to be resolved as a separate reflector on our seismic profiles. The fact that the reflector retains its position at the Ypresian/Lutetian contact for hundreds of kilometers from the shoreline to the continental rise argues against significant diachronism.

The Ypresian/Lutetian contact on the New Jersey margin corresponds to the contact between supersequences $\mathrm{Ta}$ and $\mathrm{Tb}$ of the Vail depositional model (Vail and Mitchum, 1979). The bounding major global unconformity 


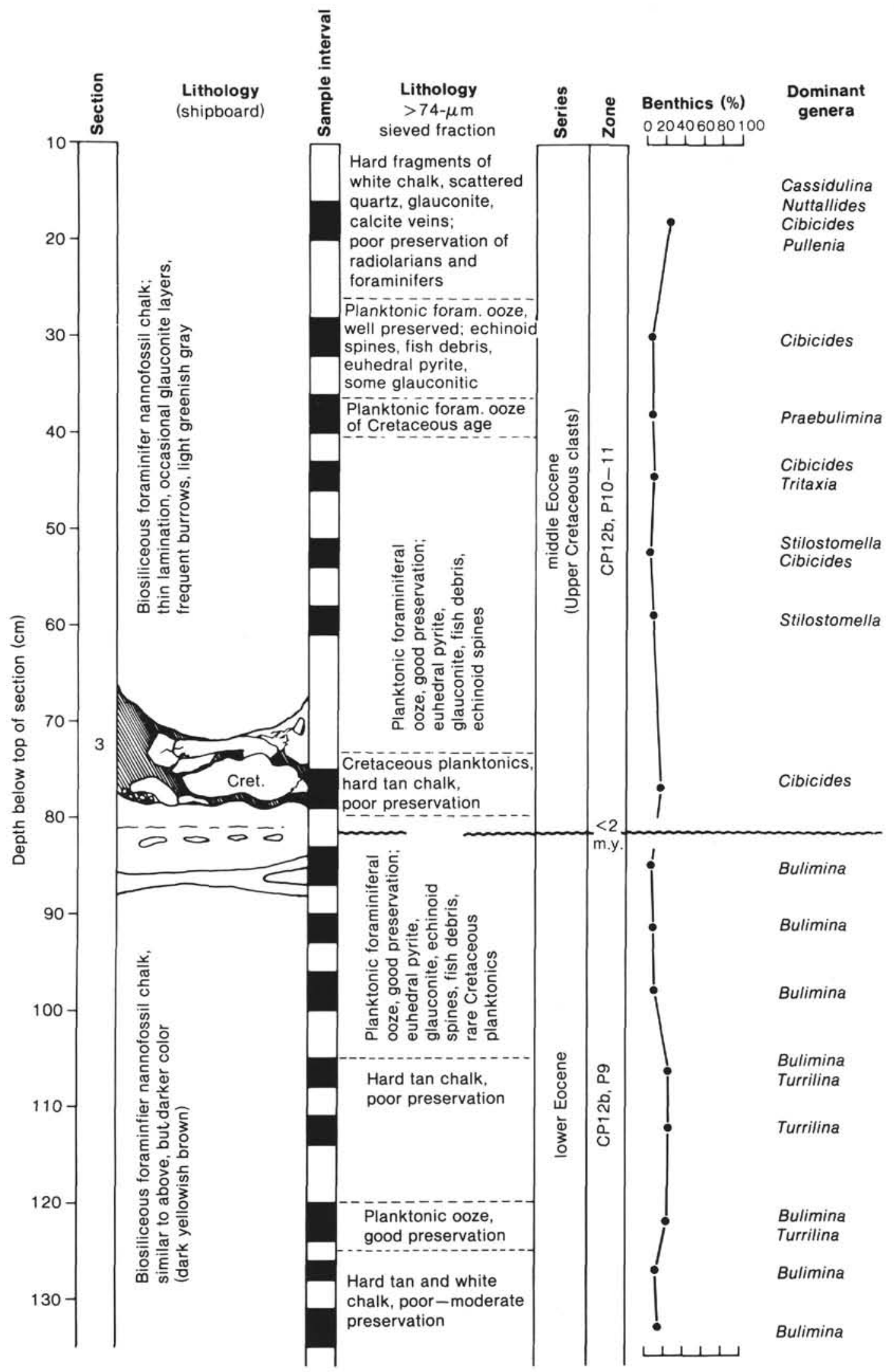

Figure 11. Chart showing lithic and benthic foraminiferal characteristics across the lower Eocene/middle Eocene contact at Site 612. See explanation of Figure 4 for additional information. 
UNCONFORMABLE SEQUENCE BOUNDARIES, SITE 612
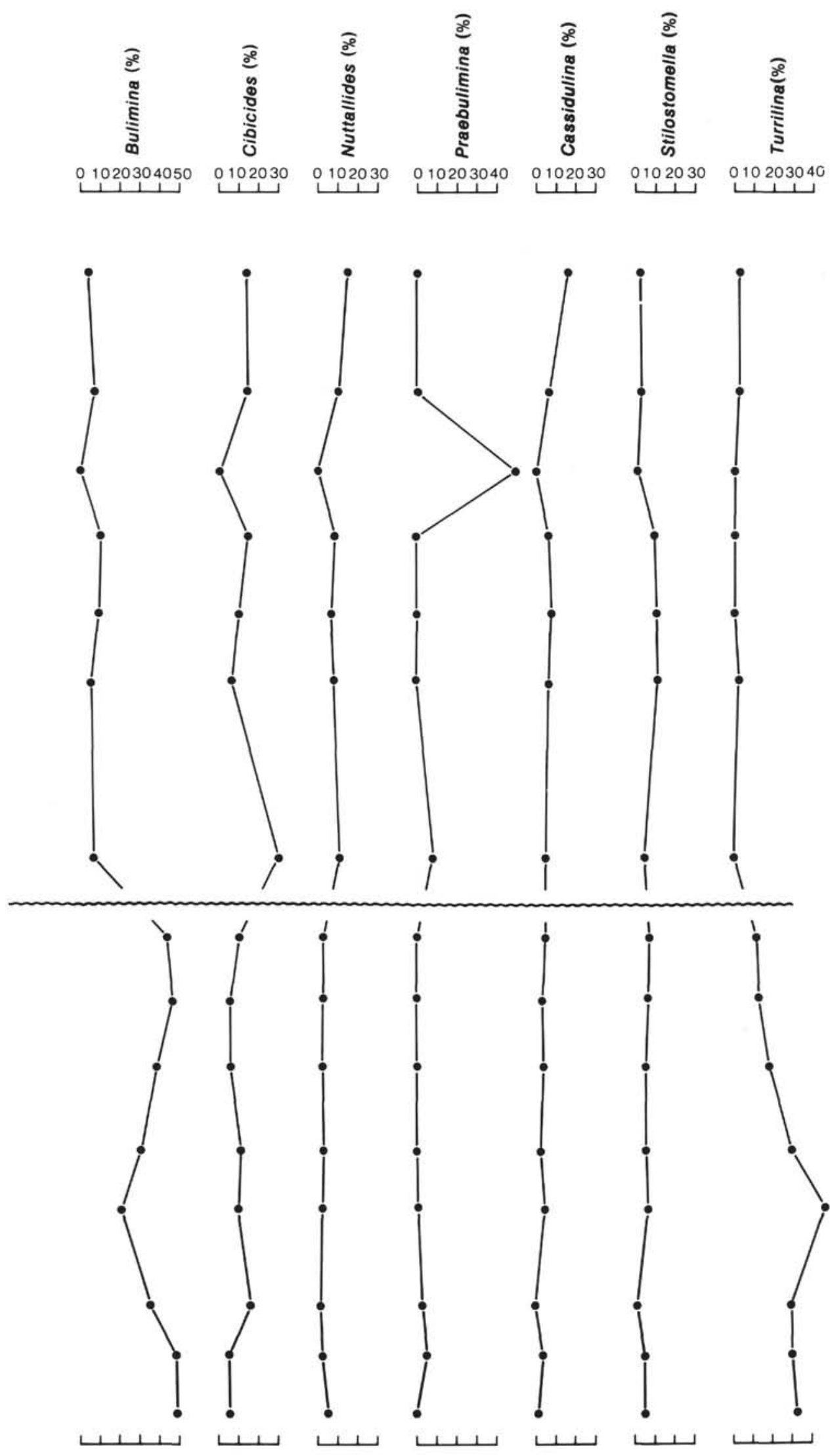

Figure 11 (continued). 


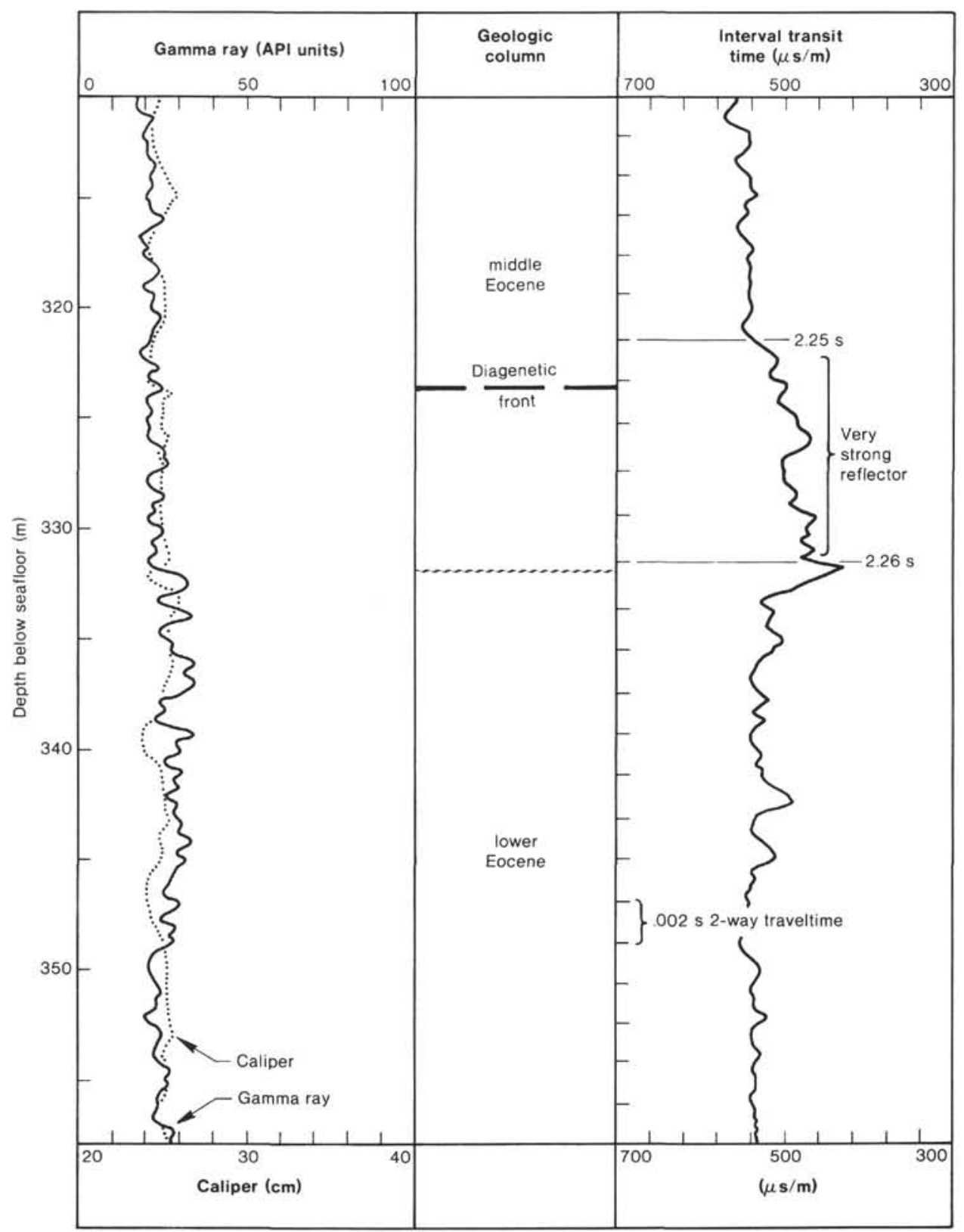

Figure 12. Downhole logging characteristics across the lower Eocene/middle Eocene contact at Site 612.

is placed by these authors within Zone P9, and the concurrent sea-level drop is estimated to have taken place at $49.5 \mathrm{Ma}$. On the Berggren time scale (Berggren et al., 1985 ) this would be $52.6 \mathrm{Ma}$. An equivalent YpresianLutetian unconformity (assuming a dating accuracy of no greater than $\sim 1$ m.y.) was documented by Poag et al. (1985) at Sites 548 and 549 on the Goban Spur (continental slope of Ireland), where it is associated with turbidite deposition. The Ypresian-Lutetian unconformity also is one of the most thoroughly documented supersequence boundaries outside the western North Atlantic. It has been recorded in Libya (Barr and Berggren, 1981), northwestern Europe (Aubry, 1985), California (Berggren and Aubert, 1983), Australia (Steele, 1976; McGowran, 1979; Quilty, 1980), and New Zealand (Loutit and Kennett, 1981a, 1981b). Such widespread erosion of equi- valent stratigraphic sections suggests a common cause, such as the change in sea level postulated for the Vail model.

\section{MIDDLE EOCENE (Lutetian)/UPPER EOCENE (Priabonian) CONTACT}

\section{Lithologic Characteristics}

The contact between the Lutetian and Priabonian sections is marked by an irregular scour surface in 612-21$5,115 \mathrm{~cm}$, which separates medium gray, biosiliceous, sparsely burrowed, nannofossil ooze (below), from dark greenish gray, glauconitic, microtektite-bearing, quartz sand (Fig. 14). The 1.5-cm-thick sand is overlain by $\sim 17 \mathrm{~cm}$ of dark brownish gray, biosiliceous, nannofossil ooze, which contains distorted inclusions of lighter 
Table 2. Census of benthic foraminiferal genera ( $\%$ of total benthic assemblage $>74 \mu \mathrm{m}$ ).

\begin{tabular}{|c|c|c|c|c|c|c|c|c|c|c|c|c|c|c|c|}
\hline \multirow[b]{2}{*}{ Genus } & \multicolumn{15}{|c|}{ 612-37-3 (interval in $\mathrm{cm}$ ) } \\
\hline & $16-20$ & $28-31$ & $36-40$ & 43-46 & $51-54$ & $58-61$ & $75-79$ & 83-87 & $90-93$ & $96-100$ & $105-108$ & $111-114$ & $120-124$ & $126-128$ & $132-135$ \\
\hline Bulimina & 3.8 & 8.0 & $-^{a}$ & 10.2 & 8.4 & 4.8 & 6.2 & 42.5 & 45.4 & 37.9 & 29.8 & 19.6 & 32.3 & 46.6 & 45.9 \\
\hline Cassidulina & 16.0 & 6.4 & - & 6.1 & 7.9 & 7.5 & 5.0 & 3.4 & 1.8 & 3.0 & 1.7 & 4.3 & - & 1.4 & 0.9 \\
\hline Cibicides & 13.6 & 13.0 & - & 14.3 & 10.7 & 5.7 & 28.6 & 9.7 & 5.3 & 5.2 & 10.6 & 8.7 & 14.5 & 4.4 & 2.2 \\
\hline Eouvigerina & - & - & 14.0 & - & 0.5 & - & 0.6 & - & 0.2 & - & - & - & - & 0.3 & - \\
\hline Nuttallides & 14.6 & 9.0 & - & 9.0 & 7.9 & 8.3 & 11.8 & 4.1 & 3.1 & 3.3 & 2.6 & 3.3 & 1.6 & 2.2 & 4.1 \\
\hline Praebulimina & - & - & 49.8 & - & - & - & 7.5 & - & - & - & - & - & 1.1 & 2.2 & - \\
\hline Pullenia & 12.7 & 6.0 & - & 6.1 & 7.5 & 7.0 & 9.3 & 2.6 & 2.2 & 3.3 & 1.3 & 2.2 & 2.2 & 0.5 & 0.3 \\
\hline Stilostomella & 2.8 & 3.3 & 1.6 & 10.2 & 11.7 & 11.4 & 5.0 & 7.5 & 6.1 & 5.5 & 5.5 & 5.4 & 1.6 & 5.2 & 5.1 \\
\hline Tritaxia & - & 5.7 & - & 11.0 & 3.7 & 8.3 & 5.0 & 0.4 & 3.5 & 3.6 & 0.9 & 1.1 & 0.5 & - & - \\
\hline Turrilina & 1.9 & 2.0 & - & - & - & 3.5 & - & 10.8 & 12.1 & 16.7 & 27.7 & 40.2 & 28.5 & 28.8 & 31.0 \\
\hline Alabamina & - & 3.0 & - & - & - & - & - & - & - & - & - & - & - & - & - \\
\hline Anomalina & 4.2 & 5.7 & - & 4.5 & 1.9 & 1.3 & - & 1.1 & 1.3 & 0.3 & 1.3 & - & 1.6 & 0.3 & - \\
\hline Aragonia & 0.9 & 1.0 & - & 4.1 & 2.8 & 0.9 & 0.6 & 1.9 & 2.4 & 3.6 & 0.4 & - & 0.5 & 1.4 & 3.8 \\
\hline Bolivinoides & - & - & 0.3 & - & - & - & 0.6 & - & 0.2 & - & - & - & 0.5 & 0.3 & - \\
\hline Clinapertina? & - & - & 4.4 & - & 1.9 & - & - & - & - & - & - & - & - & - & - \\
\hline Dentalina & - & 3.3 & 0.6 & 1.2 & 0.9 & 0.4 & - & - & - & - & - & - & - & - & - \\
\hline Dorothia & - & 2.3 & - & 2.0 & 3.3 & - & - & 0.4 & 1.8 & 2.1 & - & - & - & 0.3 & 0.3 \\
\hline Ellipsoglandulina & - & 0.3 & - & - & - & - & - & - & - & - & - & - & - & - & - \\
\hline Epistominella & 1.9 & - & - & - & - & - & - & - & - & - & - & - & - & - & - \\
\hline Eponides & - & - & - & - & - & 5.7 & 1.9 & - & - & 0.9 & - & - & - & - & - \\
\hline Fissurina & 0.5 & 0.7 & - & 0.4 & 0.5 & 3.5 & 0.6 & - & - & - & 0.4 & - & - & - & - \\
\hline Gaudryina & - & 1.7 & 2.5 & - & - & - & - & - & - & - & - & - & - & - & - \\
\hline Gavelinella & 2.8 & 2.3 & 6.5 & 0.4 & 0.5 & 0.4 & 1.9 & - & - & - & - & 5.4 & 1.6 & 0.3 & 0.3 \\
\hline Gyroidina & 3.8 & 1.3 & 4.4 & 1.2 & 2.3 & 1.8 & 4.3 & 1.1 & - & 0.9 & 2.6 & 3.3 & 0.5 & - & 0.6 \\
\hline Hanzawaia & - & - & - & - & - & - & 1.1 & - & 0.2 & - & 0.4 & - & - & - & - \\
\hline Hoeglundina & - & - & - & - & - & - & - & - & - & - & - & - & 0.5 & - & - \\
\hline Kolesnikovella & - & - & - & - & - & - & 0.4 & - & 0.9 & 0.3 & 1.3 & - & - & - & - \\
\hline Lagena & 0.5 & 1.0 & - & 0.4 & 1.4 & 0.4 & 0.6 & 0.4 & 0.2 & 0.6 & - & - & - & - & \\
\hline Lenticulina & 9.4 & 5.0 & 0.3 & 4.9 & 5.1 & 5.7 & 12.4 & 5.6 & 4.8 & 3.3 & 4.3 & 3.3 & 7.5 & 4.1 & 2.8 \\
\hline Loxostomum & - & - & 5.6 & - & - & - & - & - & - & - & - & - & - & - & - \\
\hline Marssonella & - & - & 0.3 & - & - & - & - & - & - & - & - & - & - & - & - \\
\hline Nodosaria & 2.8 & 2.0 & - & - & 0.5 & 2.2 & 1.2 & - & - & - & - & - & 1.1 & - & - \\
\hline Nuttallinella & - & - & 0.9 & - & - & - & - & - & - & - & - & - & - & - & - \\
\hline Oridorsalis & 3.8 & 1.0 & 0.6 & 0.4 & 0.5 & 1.3 & 3.1 & 0.4 & 1.3 & 1.8 & 3.0 & - & 4.3 & - & 0.9 \\
\hline Osangularia & - & 0.7 & - & 2.9 & 4.7 & 1.3 & 3.1 & 1.5 & 1.1 & 1.2 & 1.3 & 2.2 & 2.2 & 2.2 & - \\
\hline Plectina & - & 2.0 & - & 2.5 & 2.3 & 6.6 & - & - & 0.2 & - & - & - & - & - & - \\
\hline Pleurostomella & - & 0.3 & - & - & 0.5 & 0.9 & - & 0.4 & 0.4 & 0.3 & - & - & - & 0.3 & 0.3 \\
\hline Polymorphina & 2.3 & 0.3 & - & - & - & - & - & - & - & - & - & - & - & - & - \\
\hline Pseudouvigerina & - & 2.0 & 3.7 & 2.0 & - & 3.9 & - & 0.4 & - & - & - & - & 1.1 & - & 0.3 \\
\hline Pulsiphonina & 0.9 & - & - & 2.9 & 4.7 & 1.8 & - & 1.9 & 2.2 & 1.8 & 2.1 & - & 1.6 & 0.8 & 0.3 \\
\hline Pyramidina & - & - & - & - & - & - & - & - & - & - & - & - & - & 0.5 & - \\
\hline Quadrimorphina & - & 1.0 & 0.9 & - & - & 2.2 & - & - & - & - & - & 1.1 & - & - & - \\
\hline Quinqueloculina & - & - & 0.3 & - & - & 0.9 & 0.6 & 0.4 & 0.2 & 0.6 & 2.1 & - & 0.5 & 0.5 & - \\
\hline Siphotextularia & - & - & - & - & - & - & - & - & - & 0.3 & - & - & - & - & - \\
\hline Spiroplectammina & 0.9 & 8.0 & - & - & 1.4 & 1.3 & - & 0.7 & 0.7 & - & 0.4 & - & 1.1 & - & - \\
\hline Textularia & - & - & - & - & - & - & 0.7 & - & 0.2 & - & - & - & - & - & - \\
\hline Trifarina & - & - & - & 0.9 & - & - & - & - & - & - & - & - & - & - & - \\
\hline Uvigerina & - & 0.3 & - & 2.9 & 5.1 & 0.9 & 0.6 & 0.7 & 1.5 & 1.2 & - & - & - & 0.3 & 0.6 \\
\hline Vaginulina & - & - & - & - & - & - & - & - & 0.7 & - & - & - & - & - & - \\
\hline Vaginulinopsis & - & 1.0 & - & - & - & - & - & - & - & - & 0.4 & - & - & - & - \\
\hline Valvulineria & - & - & 0.3 & - & - & - & - & - & - & 1.5 & - & - & - & - & - \\
\hline Vulvulina & - & - & - & - & - & - & - & - & - & 0.6 & - & - & - & - & - \\
\hline$" X "$ & - & - & 2.8 & - & - & - & - & - & - & - & - & - & - & - & - \\
\hline Total specimens & 213 & 299 & 321 & 244 & 214 & 228 & 161 & 268 & 456 & 330 & 235 & 92 & 186 & 365 & 316 \\
\hline$\%$ Benthics & 24 & 9 & 6 & 10 & 8 & 9 & 14 & 8 & 7 & 9 & 18 & 21 & 22 & 9 & 11 \\
\hline No. of benthic genera & 20 & 31 & 19 & 22 & 27 & 28 & 18 & 25 & 25 & 25 & 21 & 13 & 20 & 18 & 17 \\
\hline
\end{tabular}

a - means not present.

gray sediment. Above this is a thick interval of light brownish gray, mottled, biosiliceous, nannofossil ooze.

The $>74-\mu \mathrm{m}$ sieved fraction of the six samples below the unconformity contains a microfossil ooze of chiefly radiolarians and planktonic foraminifers. Diatoms, sponge spicules, and fish skeletal debris are also present, along with a few shards of glass (Fig. 15), which Thein (this volume) attributes to a bolide impact. No sample was taken in the sand immediately above the contact, where Thein (this volume) and Cousin and Thein (this volume) have identified microtektites in a matrix of angular quartz, feldspar, glauconite, and clay clasts; they interpret this layer as a reworked impact breccia. In Sample 612-21-5, $105-109 \mathrm{~cm}$, in the dark brownish gray ooze, a very small residue is dominated by radiolarians and euhedral pyrite; foraminifers are sparse. In Sample 612-21-5, 97$101 \mathrm{~cm}$, a residue from the top of the dark ooze contains hard lumps of tan clay and abundant framboidal pyrite, radiolarians, diatoms, and planktonic foraminifers. Echinoid spines, sponge spicules, and fish skeletal debris are less abundant. A few glauconite and quartz grains also are present. The tan clay is partly soluble in dilute $\mathrm{HCl}$, but leaves a residue of thin brown flakes.

From Section 612-21-5, 65 to $94 \mathrm{~cm}$, residues from 4 samples of the lighter brownish gray ooze (Fig. 15) have approximately the same constituents as below, lacking only the tan clay lumps. The uppermost sample (612-21$5,57-61 \mathrm{~cm})$ is similar, but diatoms are notably scarce. 


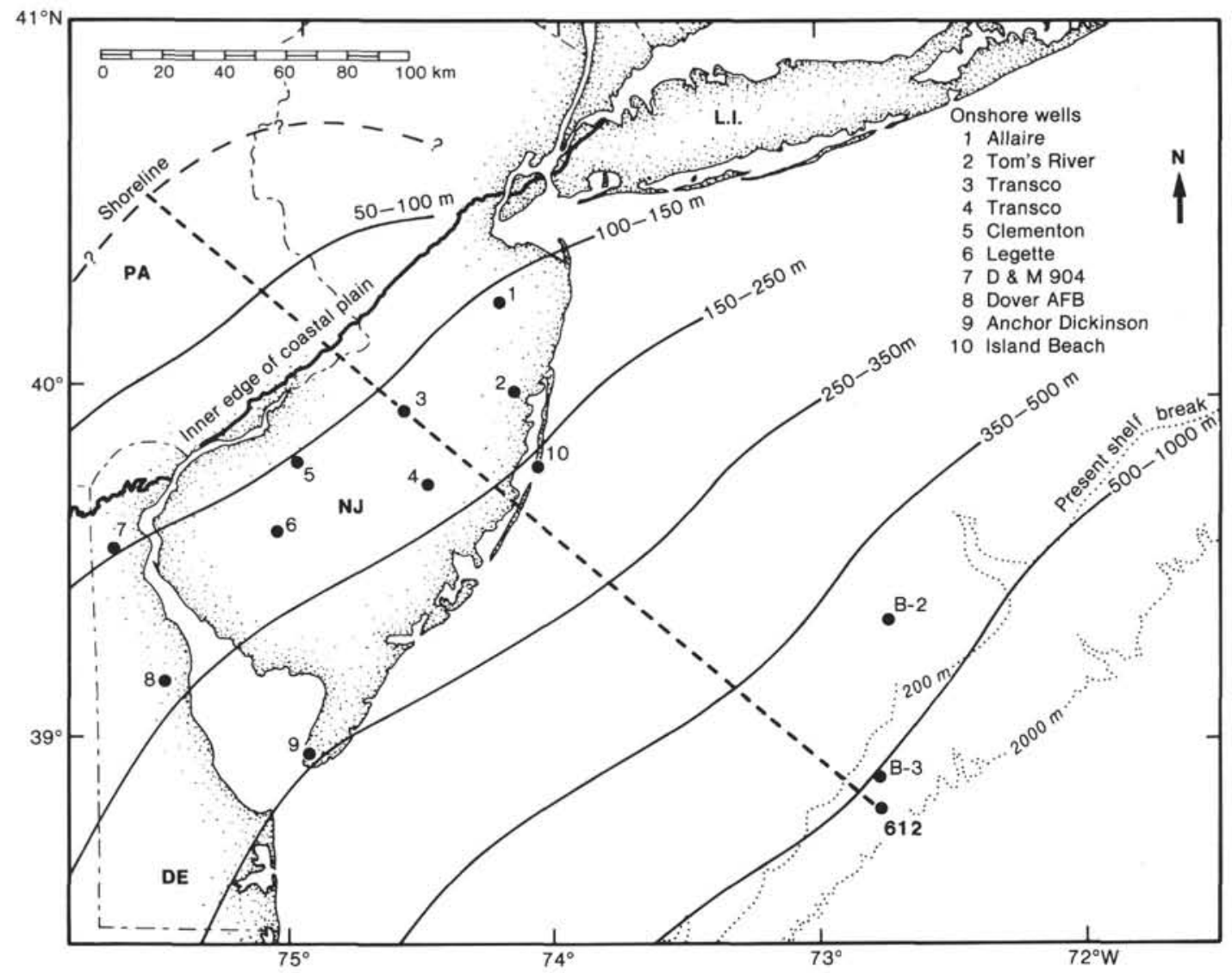

Figure 13. Generalized early Eocene seafloor morphology based on comparison of benthic foraminiferal assemblages with modern analogs. Onshore data from Charletta (1980) and Benson et al. (1985).

\section{Biochronology}

A diverse assemblage of well-preserved planktonic foraminifers from below the unconformity includes: Hantkenina mexicana dumblei, Globigerinatheka index, Morozovella lehneri, $M$. spinulosa, Acarinina densa, A. broedermanni, A. matthewsae, Subbotina frontosa, Globigerinoides(?) higginsi, and Hastigerina(?) bolivariana. This assemblage is diagnostic of Zone P11 (Blow, 1979), but includes a few younger forms (Hantkenina alabamensis, Truncorotaloides topilensis, $T$. rohri) that probably came from the burrows.

The first diagnostic assemblage from above the unconformity, at the top of the dark ooze (Sample 612-21$5,97-101 \mathrm{~cm}$ ), is sparse, but contains Globigerina cerroazulensis cerroazulensis, G. linaperta, Dentoglobigerina galavisi, Globorotaloides suteri(?), and Globigerinatheka semiinvoluta. This assemblage belongs to Zone P15. Redeposition of middle Eocene specimens into this upper Eocene section is manifested by the presence of $\mathrm{Mo}$ rozovella lehneri. These assemblages indicate that the hiatus represented by the Lutetian-Priabonian unconformity is approximately $6 \mathrm{~m}$.y. long.

\section{Geophysical Characteristics}

The gamma-ray curve displays a distinct upward increase in value across the Lutetian/Priabonian contact, coincident with a moderate upward decrease in sonic ve- locity at $2.09 \mathrm{~s}$ on the integrated sonic $\log$ (Fig. 16). This depth corresponds to the position of a strong unconformable reflector that crosses Site 612 along Line 25, and can be easily traced updip and downdip from the borehole (see Fig. 6).

\section{Benthic Foraminiferal Characteristics}

Striking changes in the benthic foraminiferal assemblages take place across the Lutetian/Priabonian contact at Site 612 (Fig. 15; Table 3). The benthic percentage increases upward from $4-7 \%$ below the contact to $12-17 \%$ above it. At the same level, Bulimina, which is predominant below the contact $(30.5-52.1 \%)$, is replaced by Bolivina (18.1-21.9\%) above the contact. Ancillary changes include the near absence of Turrilina above the contact, although it is persistent $(4.8-11.0 \%)$ below. Cassidulina and Gyroidina, on the other hand, are consistently more abundant above the contact.

The numbers of benthic genera (Table 3 ) do not vary significantly across the contact and are similar to those near the Ypresian-Lutetian unconformity.

\section{Interpretation}

During the middle Eocene, the regional depositional patterns off New Jersey changed considerably. A prograded prism ( $200 \mathrm{~m}$ thick) of middle Eocene sediments accumulated near the shoreward end of Line 25 , creat- 


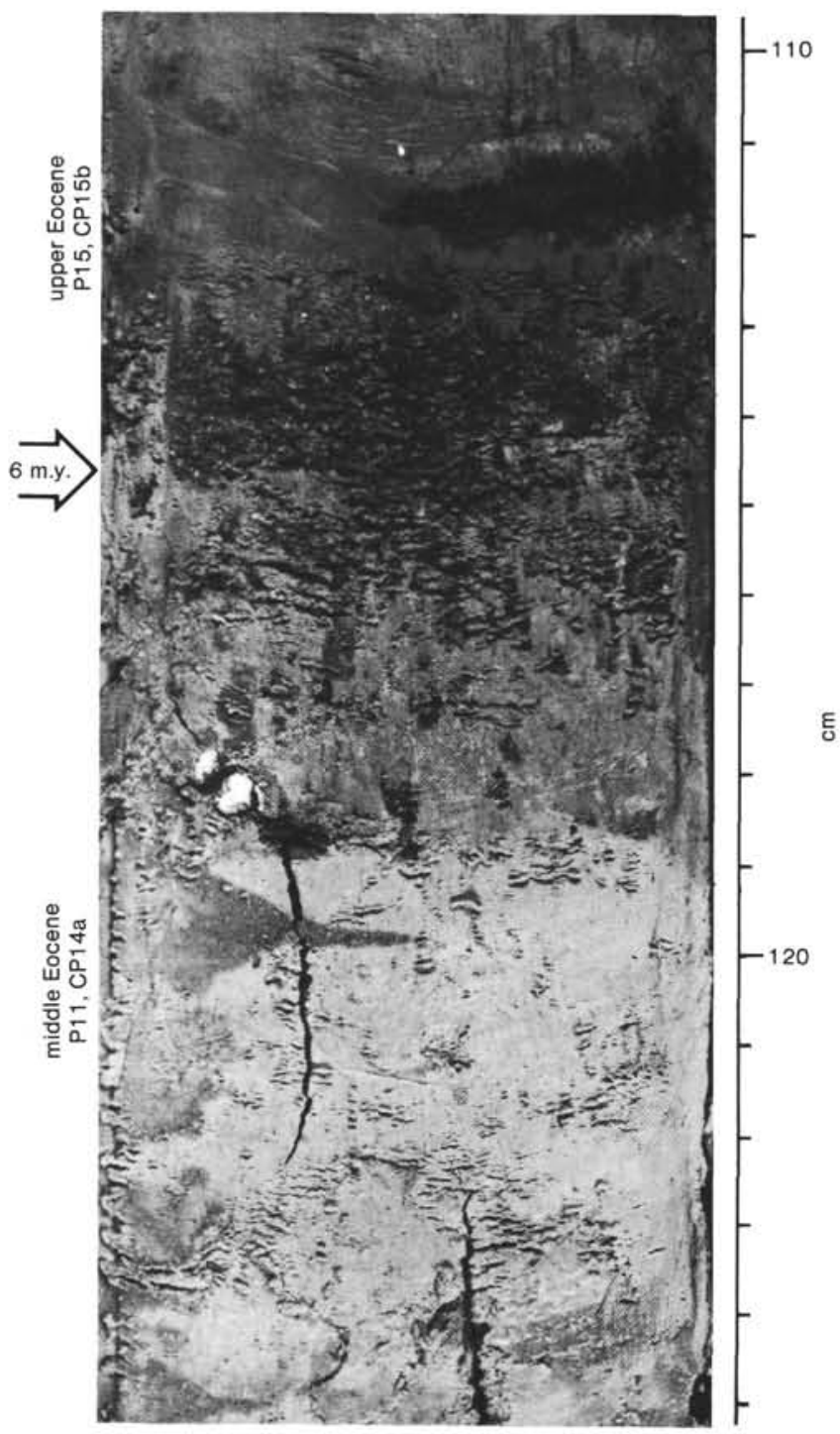

Figure 14. Photograph of the unconformable contact between the middle Eocene and upper Eocene sequences at Site 612 (Section 612 21-5).

ing a shelf break with about $75 \mathrm{~m}$ relief at shotpoint 750 (Fig. 7). From there, a relatively thin $(50-100 \mathrm{~m})$ middle Eocene unit slopes seaward across the Baltimore Canyon trough, finally thickening into a prograded slopefront fill ( $200 \mathrm{~m}$ thick or more) near shotpoint 3200 (Fig. 7). This shelf break has been deeply eroded. Thus, a second middle Eocene "shelf break" developed near the buried Late Cretaceous shelf edge. In other words, on the upper Eocene surface (Line 25), we can distinguish a 130-km wide inner shelf (shoreward of shotpoint 750 ) and a 200-km wide outer shelf (between shotpoints 750 and 2800); both shelf segments are marked at their seaward edges by a shelf break. The light color of the middle Eocene sediment at Site 612 and its pelagic calcareous composition indicate that deposition took place on a well-aerated seafloor far from a source of terrigenous detritus. Nutrient-rich surface waters are indicated by the abundance of radiolarians and diatoms.
Comparison with the modern analog would place the middle Eocene foraminiferal assemblages in bathyal water depths (500-1000 m; Fig. 17), as indicated by the predominance of Bulimina, the composition of the associated benthic assemblages, and the low benthic percentage. This is similar to the estimate of Poag (1980, $1985 \mathrm{a})$ for the COST B-3 well $(\sim 1000 \mathrm{~m})$, and of Miller and Katz (this volume) for Site $612(\sim 1000 \mathrm{~m})$.

The Campanian paleoslope model, using coastal plain paleodepth estimates of Charletta (1980) and a seafloor slope of $1 \mathrm{~m} / \mathrm{km}$ yields a paleodepth of $100-200 \mathrm{~m}$ at the inner shelf break. The middle Eocene seafloor between here and the outer shelf break would have to slope at $8 \mathrm{~m} / \mathrm{km}$ to produce $1000-\mathrm{m}$ water depths at Site 612 .

This setting was disturbed sometime during the transition from the middle to the late Eocene by erosive bottom currents or sediment gravity flows. Extensive downslope channeling at this stratigraphic level on the continental rise (Site 613; Poag, 1985b; Poag and Mountain, this volume) indicates that gravity flows rather than contour currents were the dominant erosional forces during this period. Deposition resumed during the early late Eocene in the form of a thin, glauconitic, quartz sand, followed by a dark, mottled, slightly quartzose ooze. The presence of terrigenous detritus is particularly significant, because it occurs within a thick carbonate sequence that extends from the continental rise to well beneath the present coastal plain (Poag, 1985a, 1985b). We conclude that a rapid fall of sea level must have moved the shoreline far out onto the inner part of the middle Eocene shelf, triggering mass movement of shelf sediments as far downslope as Site 612 .

Following the sand deposition, the dominance of $\mathrm{Bo}$ livina among the benthic foraminifers, the dark sediment color, the abundance of pyrite, and the sparsity of distinct burrows, suggest that bottom (or interstitial) waters were deficient in oxygen compared to the interval preceding the erosion (see Poag and Low [1985]; and Poag [1985c] for discussion of the implications of Bolivina predominance). Miller and Katz (this volume) conclude that unspecified paleoceanographic changes associated with initial cooling of seafloor water masses produced the foraminiferal shifts they documented at this stratigraphic level at Site 612 .

\section{Regional Relationships}

The seismic expression of this contact is widely traceable throughout the New Jersey margin (Poag, 1985a, 1985b). It has been documented in several shelf wells, and is well known across the adjacent coastal plain (Ward, 1984; Ward and Strickland, 1985). It is particularly notable basinward from Site 612, where the unconformity is exposed at the seafloor as a broad submarine outcrop of middle Eocene chalk (Hollister, Ewing, et al., 1972; Robb et al., 1983; Poag, 1985b; Hampson and Robb, 1984; Farre, 1985; Farre and Ryan, 1985). Farther seaward it is onlapped by Tertiary and Quaternary sequences of the continental rise (Tucholke and Mountain, 1979; Mountain and Tucholke, 1985; Poag, 1985b; Poag and Mountain, this volume; see Sites 605, 613). Popenoe 
C. W. POAG, D. LOW

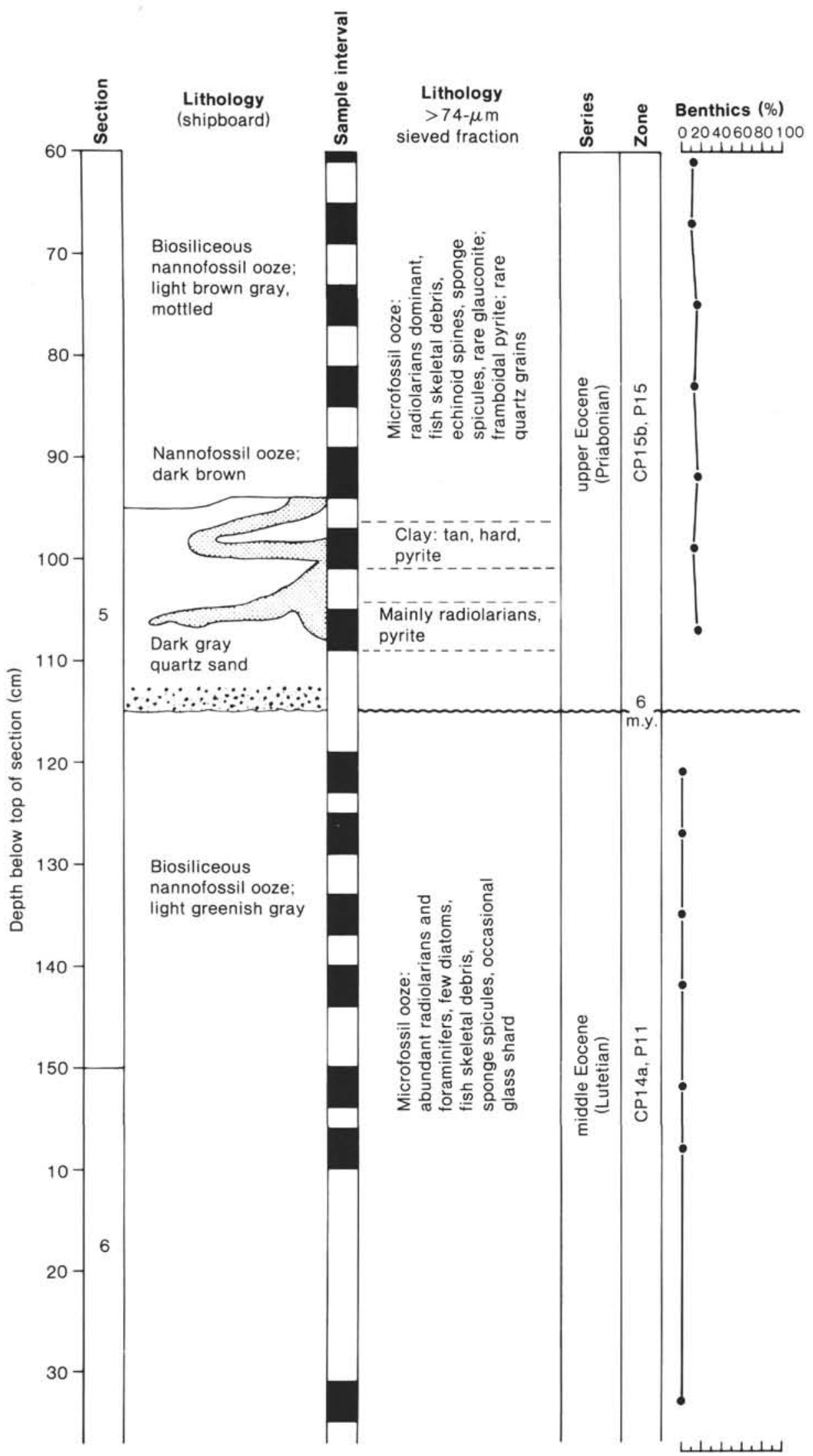

Figure 15. Chart showing the lithic and benthic foraminiferal characteristics across the middle Eocene/upper Eocene contact at Site 612 . 
UNCONFORMABLE SEQUENCE BOUNDARIES, SITE 612

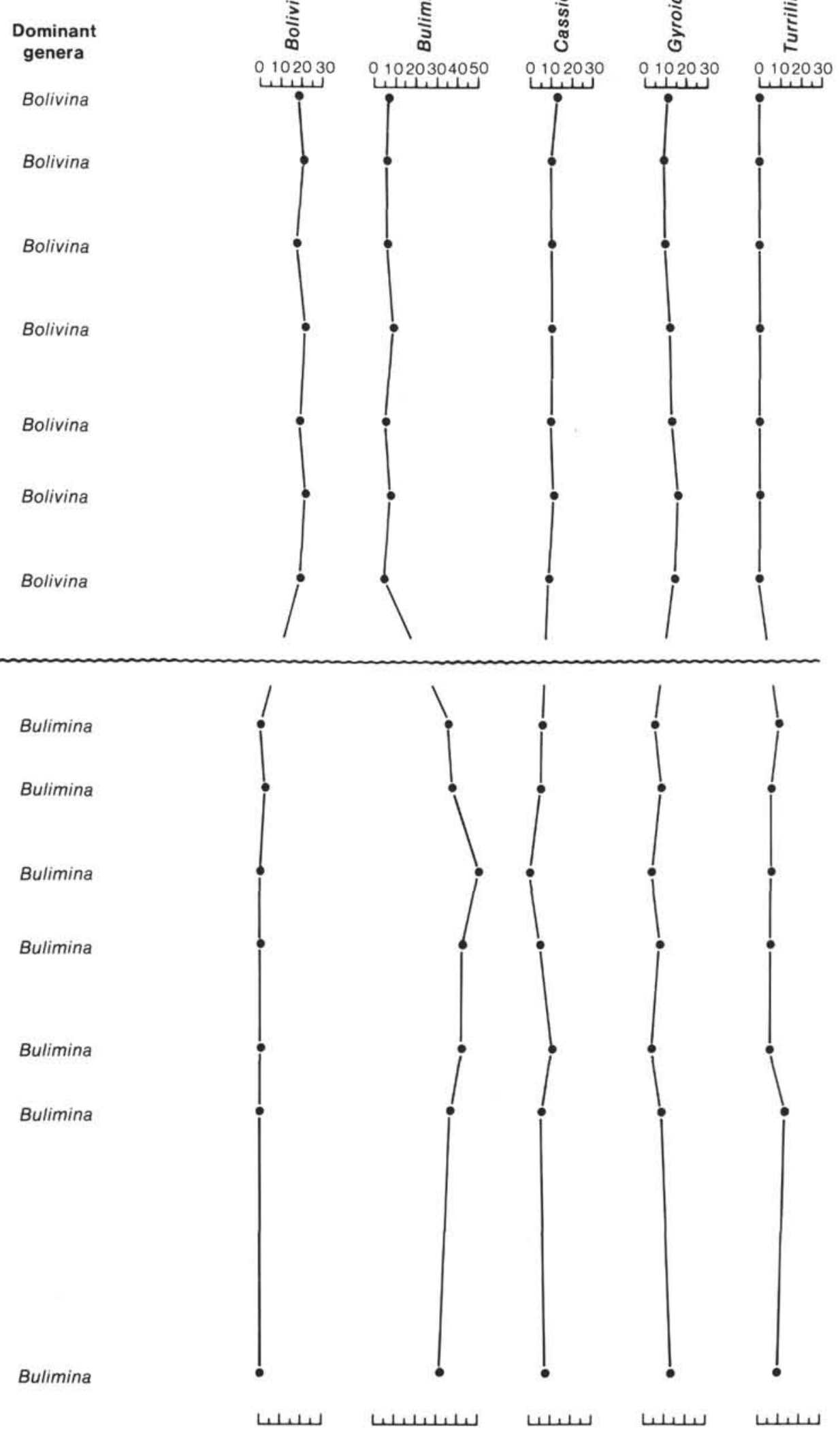

Figure 15 (continued). 


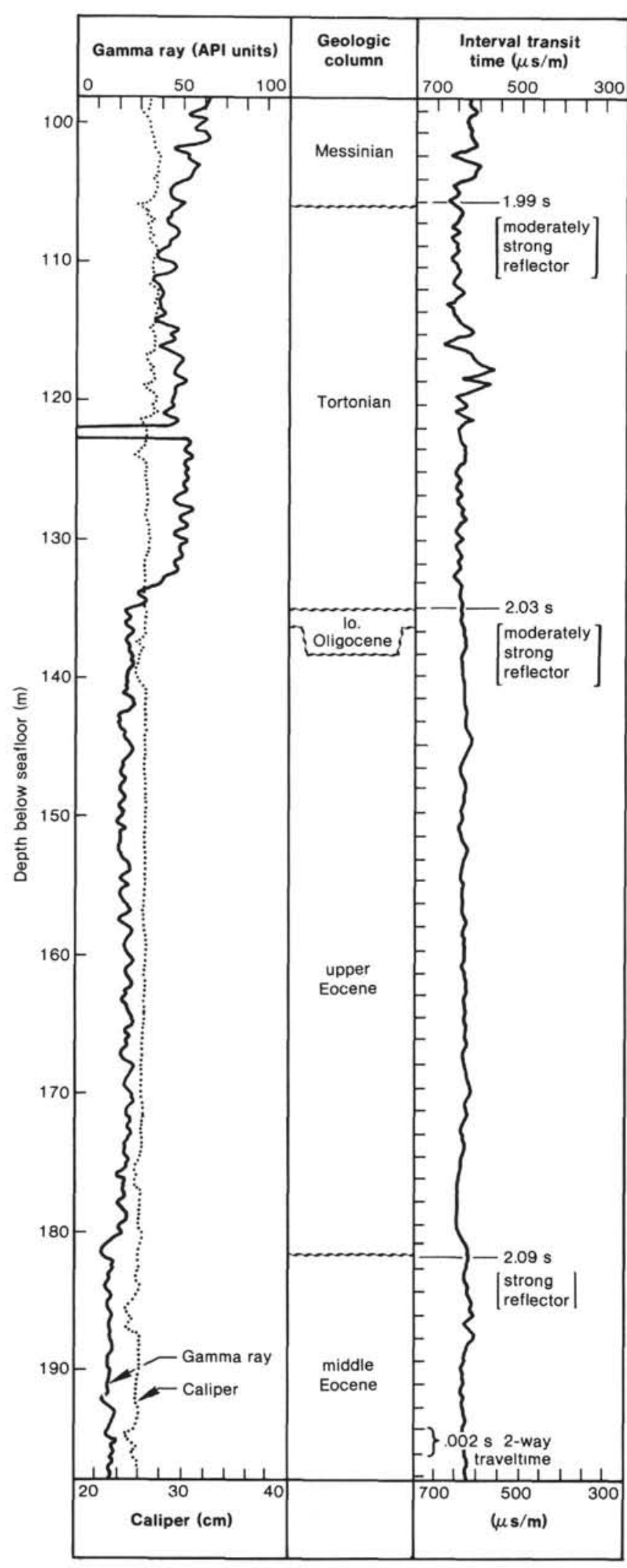

Figure 16. Downhole logging characteristics across the middle Eocene/ upper Eocene, upper Eocene/lower Oligocene, lower Oligocene/ upper Miocene, and Tortonian/Messinian contacts at Site 612.
(1985) noted that this unconformity is expressed on seismic profiles off North Carolina as a seaward erosional swath of the paleo-Gulf Stream.

The Lutetian/Priabonian contact at Site 612 corresponds to the contact between supersequences $\mathrm{Tb}$ and $\mathrm{Tc}$ of the Vail depositional model (Vail and Mitchum, 1979), which is placed between planktonic foraminiferal zones P14 and P15 (Fig. 15). It coincides with a major sea-level fall and global unconformity, which Vail and Mitchum date at $40 \mathrm{Ma}$. Berggren et al. (1985) would place the P14/P15 contact at 40.2-41.2 Ma. Snyder and Waters (1985) examined this stratigraphic interval on the Goban Spur, but did not report an unconformity associated with the P14/P15 boundary. We reexamined the zonal boundary interval at Site 548 and found a distinct erosional contact at 548A-18-2, $25 \mathrm{~cm}$ (Fig. 18), between the sample assigned by Snyder and Waters to P14 (Sample 548A-18-2, 65-68 cm; having abundant Truncorotalia topilensis) and our Sample 548A-18-1, 110-112 cm (P15; having no T. topilensis). An unconformity at this contact also has been recorded from New Zealand (Loutit and Kennett, 1981a, 1981b) and from Australia (Steele, 1976; McGowran, 1979; Quilty, 1980).

\section{UPPER EOCENE (Priabonian)/LOWER OLIGOCENE (Rupelian) CONTACT}

\section{Lithologic Characteristics}

Priabonian strata consist of grayish, yellow green, homogeneous, biosiliceous, foraminiferal, nannofossil ooze, which extends upward from Section 612-17-1 to the top of $612-16, C C$. Section 7 and basal Section 6 of Core 612-16 comprise distinctly lighter-gray, biosiliceous, foraminiferal, nannofossil ooze. There is no transition between the two lithologies, and no contact was recovered; it apparently was lost between $612-16, C C$ and the base of Section 612-16-7. The nature of this contact was not realized until this chapter was nearly finished, therefore closeup photographs of the cores are not available. However, because the original contact appears not to have been recovered, the lack of photographs is not a severe handicap.

The washed residues of the $>74-\mu \mathrm{m}$ size fraction are more diagnostic than shipboard descriptions and photographs for separating these sequences (Fig. 19). The lighter gray Oligocene ooze contains abundant volcanic glass shards, which are completely absent from the grayish, yellow green ooze below Section 612-16-7.

\section{Biochronology}

The foraminiferal assemblage of Section $612-16-7$ is a typical early Oligocene planktonic association as described in more detail in the following section. On the other hand, Sample 612-16,CC and Section 612-17-1 contain Hantkenina alabamensis, a diagnostic late Eocene (Zone P16-lower P17) marker.

\section{Geophysical Characteristics}

The Oligocene interval is so thin that its upper and lower contacts cannot be resolved as separate reflectors on Line 25 (see discussion of Oligocene/Miocene con- 
Table 3. Census of benthic foraminiferal genera ( $\%$ of total benthic assemblage $>74 \mu \mathrm{m}$ ).

\begin{tabular}{|c|c|c|c|c|c|c|c|c|c|c|c|c|c|c|c|}
\hline \multirow[b]{2}{*}{ Genus } & \multicolumn{11}{|c|}{$612-21-5$ (interval in $\mathrm{cm}$ ) } & \multicolumn{4}{|c|}{ 612-21-6 (interval in cm) } \\
\hline & $57-61$ & $65-69$ & 73-77 & $81-85$ & $89-94$ & $97-101$ & $105-109$ & $119-123$ & $125-129$ & $133-137$ & $140-144$ & $0-4$ & $6-10$ & $32-36$ & $120-124$ \\
\hline Bolivina & 19.0 & 20.9 & 18.1 & 21.2 & 19.8 & 21.9 & 19.1 & 1.2 & 2.1 & 0.3 & 0.5 & 0.7 & 0.7 & 0.5 & 1.3 \\
\hline Bulimina & 5.8 & 5.0 & 6.3 & 8.8 & 5.0 & 9.3 & 6.2 & 35.3 & 36.3 & 52.1 & 41.1 & 42.8 & 36.8 & 30.5 & 41.8 \\
\hline Cassidulina & 13.0 & 9.6 & 8.6 & 9.3 & 8.9 & 11.1 & 8.4 & 4.6 & 4.2 & $-\mathbf{a}^{\mathrm{a}}$ & 4.4 & 10.4 & 5.7 & 7.3 & 6.4 \\
\hline Gyroidina & 12.0 & 7.2 & 9.2 & 11.9 & 10.9 & 14.1 & 13.5 & 2.5 & 6.9 & 2.0 & 5.9 & 2.6 & 5.0 & 10.2 & 8.4 \\
\hline Pullenia & 7.6 & 8.0 & 13.2 & 7.4 & 4.7 & 5.4 & 9.0 & 4.6 & 4.2 & 2.5 & 4.1 & 1.5 & 3.0 & 2.2 & 2.7 \\
\hline Stilostomella & 9.3 & 8.5 & 11.2 & 8.8 & 8.0 & 7.2 & 5.6 & 3.1 & 3.8 & 3.4 & 5.6 & 2.2 & 5.7 & 5.4 & 7.7 \\
\hline Turrilina & - & - & - & - & 0.3 & - & - & 9.8 & 6.2 & 6.5 & 7.4 & 4.8 & 11.0 & 7.3 & 6.0 \\
\hline Alabamina & - & - & - & - & - & - & - & 6.1 & 3.5 & 0.8 & 2.6 & 0.4 & 5.4 & 2.7 & 1.3 \\
\hline Anomalina & 0.9 & 3.3 & 4.3 & 3.4 & 4.1 & 1.8 & 6.7 & - & - & - & - & - & - & - & - \\
\hline Astrononion & - & - & - & - & - & 0.6 & - & - & - & - & - & - & - & - & - \\
\hline Baggatella & - & 1.4 & 1.3 & 0.5 & 1.5 & - & - & - & - & - & - & - & - & - & - \\
\hline Buliminella & 5.2 & 3.0 & 4.3 & - & 2.7 & 4.5 & 1.1 & - & - & - & - & 0.7 & - & - & 0.3 \\
\hline Charltonina & - & - & - & - & - & - & 2.2 & - & - & - & - & - & - & - & - \\
\hline Cibicides & 2.3 & 1.9 & 1.0 & 1.3 & 2.7 & 2.4 & 2.2 & 6.1 & 4.5 & 4.8 & 3.1 & 8.6 & 5.0 & 5.4 & 4.4 \\
\hline Clinapertina & - & - & - & 1.1 & 2.1 & 1.2 & 1.7 & - & 1.7 & 3.1 & 0.8 & 4.8 & 3.0 & - & 0.3 \\
\hline Dentalina & 1.5 & 3.0 & 2.0 & 2.1 & - & 1.8 & 2.2 & 2.5 & 3.8 & 2.0 & 2.1 & 6.7 & 3.3 & 2.7 & 0.7 \\
\hline Eggerella & - & - & - & - & - & - & - & - & - & 0.3 & 1.1 & - & 0.3 & - & - \\
\hline Ellipsoglandulina & - & - & - & - & - & - & - & - & - & - & - & 0.4 & - & - & - \\
\hline Eouvigerina & - & 0.6 & 1.7 & 1.1 & 1.2 & - & 0.6 & 1.2 & - & - & - & - & - & - & - \\
\hline Epistominella & 1.5 & 3.3 & - & 1.1 & 1.5 & 0.3 & 0.6 & - & 1.4 & - & 0.7 & - & 0.3 & 0.8 & 0.3 \\
\hline Eponides & 4.1 & 6.1 & 6.3 & 4.2 & 7.4 & 5.1 & 2.8 & - & - & - & - & - & - & - & - \\
\hline Fissurina & 1.2 & - & - & 0.5 & - & 0.3 & 1.1 & 0.9 & 0.3 & 2.5 & 0.7 & 1.5 & 1.0 & 1.0 & 1.0 \\
\hline Florilus & 0.3 & - & - & - & - & - & 2.8 & - & - & - & - & - & - & - & - \\
\hline Fursenkoina & - & - & - & - & - & - & - & - & - & - & - & - & - & 0.3 & - \\
\hline Gaudryina & - & 0.6 & - & - & 0.3 & 0.3 & - & 1.5 & 3.1 & 2.5 & 0.5 & - & - & - & - \\
\hline Gavelinella & 0.3 & 0.3 & - & 0.3 & 0.3 & - & - & - & - & - & 0.2 & - & - & - & - \\
\hline Glabratella & 0.3 & - & - & - & - & - & - & - & - & - & - & - & - & - & - \\
\hline Glandulina & - & - & - & - & - & 0.9 & - & - & - & - & 0.2 & - & - & - & 0.3 \\
\hline "Hanzawaia" & - & - & - & - & - & - & - & - & 0.3 & 1.1 & 0.5 & 0.4 & - & - & - \\
\hline Heronallenia & - & 0.3 & - & - & - & - & - & - & - & - & - & - & - & - & 0.3 \\
\hline Karneriella & - & - & - & - & 0.3 & - & - & 0.6 & - & - & - & - & - & 0.8 & - \\
\hline Kolesnikovella & - & - & - & - & - & - & - & - & - & - & - & 0.4 & 0.7 & - & - \\
\hline Lagena & 1.7 & 1.1 & 1.0 & 1.3 & 2.7 & 1.2 & 3.9 & 0.9 & 0.7 & - & 1.5 & 2.6 & 0.7 & 2.7 & 0.7 \\
\hline Lenticulina & 0.6 & 2.5 & 1.7 & 2.1 & 2.1 & 2.0 & 2.2 & 4.6 & 3.1 & 3.1 & 2.1 & 6.3 & 4.0 & 5.4 & 2.0 \\
\hline Loxostomum & - & 1.7 & 1.0 & 1.3 & 0.9 & - & - & - & - & - & - & - & - & 0.3 & - \\
\hline Melonis & 0.6 & 0.3 & - & - & 0.3 & - & - & - & - & - & - & - & - & - & - \\
\hline Nodosaria & 0.6 & 0.8 & 0.3 & 0.5 & 2.1 & - & - & - & - & - & 0.5 & 0.4 & 0.7 & - & - \\
\hline Nuttallides & 1.5 & 1.1 & 4.6 & 0.5 & 0.3 & 0.9 & 1.1 & 0.6 & 4.2 & 0.6 & 2.1 & 4.8 & 1.3 & 0.8 & 1.7 \\
\hline Oridorsalis & 0.3 & - & - & 1.1 & 0.6 & - & - & - & & 0.6 & - & - & - & 0.5 & - \\
\hline Osangularia & 0.3 & 1.1 & - & 0.8 & 0.9 & 0.9 & - & 1.5 & - & 0.6 & 1.2 & - & 1.0 & 0.5 & 1.3 \\
\hline Parafissurina & - & - & - & - & - & - & - & - & - & - & - & - & 0.7 & - & - \\
\hline Plectina & - & - & - & - & - & - & - & - & - & - & - & 1.5 & 1.0 & 1.3 & 1.7 \\
\hline Plectofrondicularia & - & - & - & - & - & - & 0.6 & 0.6 & - & - & - & - & - & - & - \\
\hline Pleurostomella & 0.6 & 0.8 & 0.6 & 0.8 & 0.3 & 1.2 & 1.1 & - & 0.3 & 0.3 & - & - & 1.0 & 1.1 & - \\
\hline Polymorphina & 1.7 & 1.9 & 0.3 & 1.9 & 0.9 & 1.8 & 1.1 & 0.9 & - & - & - & - & - & - & 0.3 \\
\hline Pseudouvigerina & - & - & - & - & - & - & - & - & - & - & 0.7 & 0.4 & 0.3 & 1.1 & 0.3 \\
\hline Pyramidina & 0.6 & - & - & - & - & - & - & - & - & 0.3 & - & 0.4 & - & - & - \\
\hline Quinqueloculina & 1.5 & - & - & 0.3 & 0.3 & 0.3 & - & 1.2 & 1.0 & 0.6 & 1.3 & 0.4 & 0.3 & 0.8 & 1.0 \\
\hline Siphonina & - & - & - & - & - & - & - & 0.9 & 0.3 & 0.3 & 0.2 & 0.4 & - & - & - \\
\hline Siphotextularia & - & - & - & 0.3 & - & - & - & - & - & 0.3 & 0.2 & - & 0.3 & 0.3 & - \\
\hline Spiroplectammina & - & - & - & - & - & 0.9 & - & 8.0 & 5.5 & 6.8 & 7.9 & 1.9 & 1.7 & 7.5 & 6.4 \\
\hline Textularia & - & - & - & - & - & 0.3 & - & - & - & - & 0.2 & - & - & - & 0.3 \\
\hline Trifarina & - & - & - & - & - & - & - & - & 1.4 & - & - & - & - & - & - \\
\hline Uvigerina & 5.2 & 3.9 & 3.0 & 2.9 & 3.6 & 2.4 & 2.8 & - & 0.3 & - & 0.7 & 1.1 & - & 0.5 & 0.7 \\
\hline Valvulineria & - & 1.9 & - & 3.2 & 0.9 & - & 1.1 & - & - & - & - & - & - & - & - \\
\hline Vulvulina & 0.3 & - & - & - & - & - & - & - & 0.7 & 0.3 & - & - & - & - & - \\
\hline Total specimens & 343 & 363 & 303 & 377 & 338 & 334 & 178 & 326 & 289 & 355 & 608 & 269 & 299 & 371 & 297 \\
\hline$\%$ Benthics & 14 & 11 & 16 & 13 & 17 & 12 & 15 & 5 & 5 & 6 & 7 & 4 & 5 & 4 & 6 \\
\hline No. of benthic genera & 30 & 28 & 21 & 29 & 32 & 27 & 25 & 23 & 25 & 25 & 31 & 28 & 27 & 27 & 27 \\
\hline
\end{tabular}

a - means not present.

tact below). Neither can a significant gamma-ray change be observed. However, the interval is clearly distinguishable on high-resolution Profiles 89 and 69, at the intersection of which Site 612 was drilled (Fig. 1D, E).

\section{Benthic Foraminiferal Characteristics}

The benthic foraminiferal assemblage changes markedly between the two lithologies as shown on Figure 19 (Table 4). Epistominella is consistently predominant in the lower Rupelian section, whereas Bolivina predominates in the upper Priabonian. Bolivina is consistently more abundant below than in any samples above Sam- ple 612-16,CC. Conversely, Cassidulina and Epistominella are important in the Rupelian, but sparse in the Priabonian. Benthic percentage is higher in the Rupelian.

\section{Interpretation}

During the latest Eocene, Bolivina continued to dominate as in the early late Eocene discussed above. This suggests that oxygen-depleted bottom waters bathed Site 612 , a site on the continental slope (Fig. 7). The low benthic percentage and the generic association indicate that bathyal depths $(500-1000 \mathrm{~m})$ prevailed during de- 


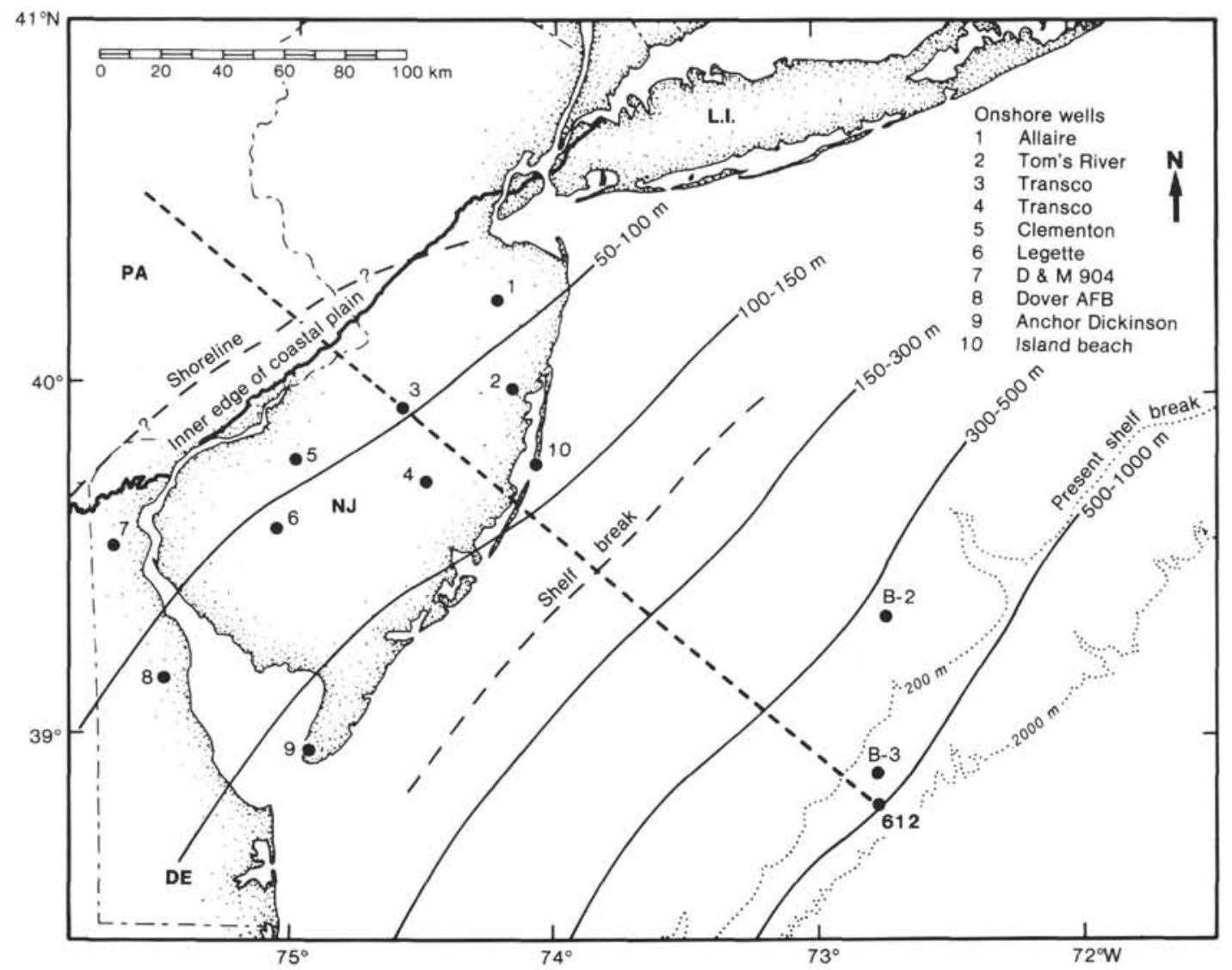

Figure 17. Generalized late middle Eocene seafloor morphology based on comparison of benthic foraminiferal assemblages with modern analogues. Onshore data from Charletta (1980) and Benson et al. (1985).

position of pelagic carbonate and biosiliceous debris. The abundance of radiolarians suggests nutrient-rich surface waters. Above the contact, Epistominella predominance and the associated benthic assemblage, along with the decrease in Bolivina, indicate a change to a more oxygen-enriched water mass; bathyal conditions still prevailed but the paleodepth may have increased to more than $1000 \mathrm{~m}$. Biosiliceous carbonates, along with the presence of abundant Bolboforma, a presumed calcareous alga (see Poag and Karowe, this volume), indicate high fertility in the surface waters. The prevalence of volcanic glass shards in the lower Oligocene strata has not been noted previously in the stratigraphic record of this region; its source is not known. It is not certain that the missing contact is an unconformable one, but its expression on high-resolution seismic reflection profiles on the continental slope shows truncation and onlap that characterize the other unconformities. A hiatus of perhaps $0.5 \mathrm{~m}$.y. is estimated for this contact.

\section{Regional Relationships}

This contact is not well documented anywhere on the New Jersey margin. At ASP 15 it was not recovered, although lower Oligocene and upper Eocene strata were penetrated. Elsewhere, across the shelf and on the coastal plain, lower Oligocene strata were removed by late Oligocene erosion (Olsson et al., 1980; Poag, 1985a). However, an equivalent upper Eocene-lower Oligocene un- conformity has been recorded in the Southeast Georgia embayment at ASP Site 5 and in the COST GE-1 well (Poag and Hall, 1978; Popenoe, 1985).

\section{LOWER OLIGOCENE (Rupelian)/UPPER MIOCENE (Tortonian) CONTACT}

\section{Lithologic Characteristics}

The contact between the Rupelian and Tortonian sections at Site 612 is marked by a sharply defined scour surface in $612-16-6,116 \mathrm{~cm}$, which separates light gray microfossil ooze below from dark gray, well-sorted, coarse, quartzose sand ( $5 \mathrm{~cm}$ thick) above (Figs. 20, 21). The coarse sand grades upward into a 1-cm interval of finer sand, which is overlain by olive gray, faintly laminated mud. We interpret the sand-to-mud section to be a turbidite.

In the $>74-\mu \mathrm{m}$ sieved fraction, the light gray ooze below the unconformity contains a rich microfossil assemblage of chiefly planktonic foraminifers, radiolarians, and Bolboforma (Fig. 21; see Poag and Karowe, this volume), accompanied by abundant glauconite grains and shards of volcanic glass. Fish skeletal debris and sponge spicules are accessory elements.

The residue of the sand in Sample 612-16-6, 112-114 $\mathrm{cm}$ is barren of microfossils, consisting of coarse to fine quartz grains, fine glauconite grains, and metamorphic rock fragments. The residues of the six samples from 


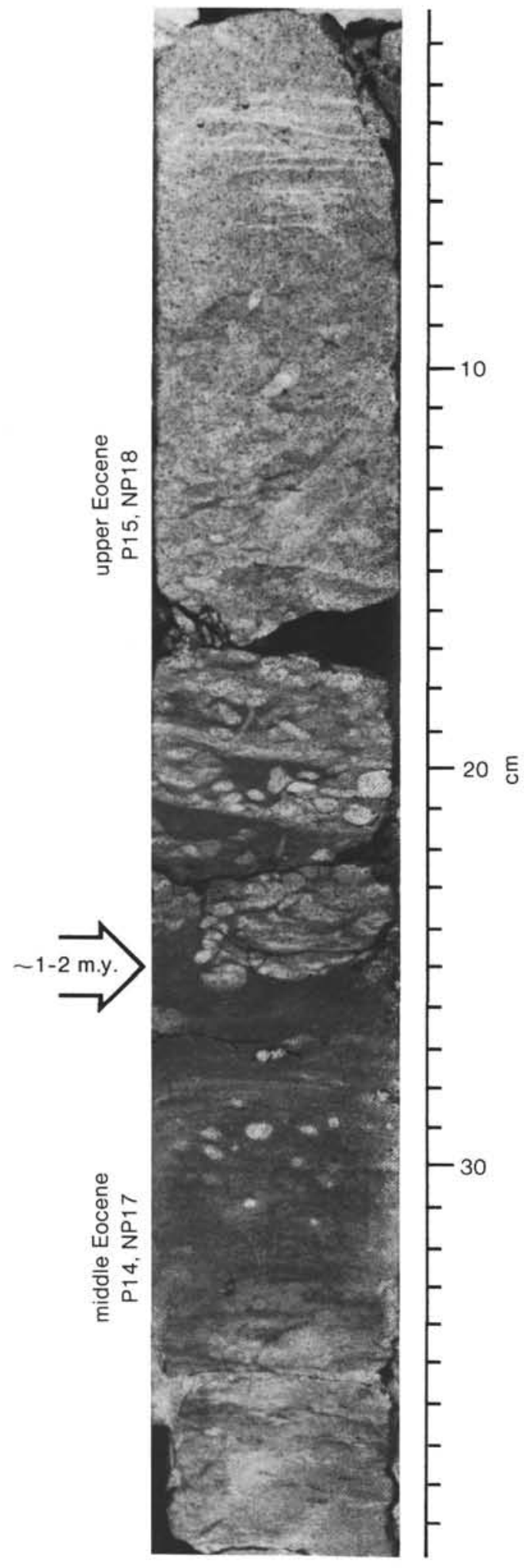

Figure 18. Photograph of the erosional contact between the middle Eocene and upper Eocene sequences at Site 548 on the Goban Spur, continental slope of Ireland (Section 548A-18-2).

the overlying mud contain fine quartz sand, mica flakes, glauconite grains, lignitic plant fragments, framboidal pyrite, radiolarians, sponge spicules, and fish skeletal debris; foraminifers are scarce to moderately abundant.

\section{Biochronology}

The rich assemblage of well-preserved planktonic foraminifers below the unconformable contact contains Globigerina ampliapertura, G. gortanii, G. increbescens, G. tapuriensis, G. praeturritilina, G. praebulloides, G. gemma, Dentoglobigerina galavisi, D. praesepis, Globorotaloides suteri, and Catapsydrax unicava, an assemblage assignable to lower Oligocene (Rupelian) Zone P18. Redeposited middle Eocene planktonics, such as Truncorotaloides rohri, are common in these assemblages, attesting to exposures of middle Eocene strata updip. Other distinctive elements of this assemblage are large numbers of Bolboforma irregularis (Poag and Karowe, this volume).

Above the barren turbidite sand that marks the unconformity, sparse planktonic foraminiferal assemblages contain Globorotalia juanai, G. menardii, G. scitula, Globigerinoides obliquus, Globigerina decoraperta, G. nepenthes, G. bulloides, Neogloboquadrina continuosa, N. acostaensis, Orbulina universa, Globoquadrina dehiscens, Sphaeroidinellopsis seminulina, and Dentoglobigerina altispira. This assemblage is assignable to upper Miocene Zone N16 of the Tortonian Stage. Thus, a hiatus of approximately $25 \mathrm{~m}$.y. is represented by the unconformable Rupelian/Tortonian contact.

The presence of a few redeposited specimens of Globorotalia siakensis, G. praefohsi, G. acrostoma, Catapsydrax unicavus, and $C$. dissimilis, indicate that middle Miocene and lower Miocene to upper Oligocene strata were exposed updip.

\section{Geophysical Characteristics}

On the downhole geophysical log, gamma-ray values increase markedly above the unconformity (Fig. 16), reflecting the abundance of terrigenous clay in the Tortonian mud. At the same level $(2.03 \mathrm{~s}$ on the integrated sonic $\log$ ), a slight decrease in sonic velocity correlates with a moderately strong seismic reflector on Line 25 (Fig. 6).

\section{Benthic Foraminiferal Characteristics}

The most striking change in the benthic foraminiferal assemblages in this section is their absence (along with all other microfossils) in the coarse sand immediately above the contact (Fig. 21; Table 4). This absence is followed by a marked increase in the percentage of benthic foraminifers $(44-93 \%$; mean $=56 \%)$ in the overlying mud as compared to the underlying Oligocene assemblages $(18-35 \%$; mean $=27 \%)$. This relative increase may reflect, in part, diagenetic alteration of the Tortonian assemblages, whose specimens are commonly pyritized and broken. No obviously displaced shallow-water species are represented in the Tortonian assemblages, although the sediments undoubtedly were derived, in part, from updip sources.

In the lowest four samples examined (Samples 612$16-7,26 \mathrm{~cm}$ to $612-16-6,135 \mathrm{~cm}$ ) Epistominella is the predominant benthic genus (20-31\%). Stilostomella becomes the dominant genus (19\%) in Sample 612-16-6, $144-148 \mathrm{~cm}$, but it is quickly replaced in Sample $612-16-6,130-126 \mathrm{~cm}$ by a more equable assemblage 


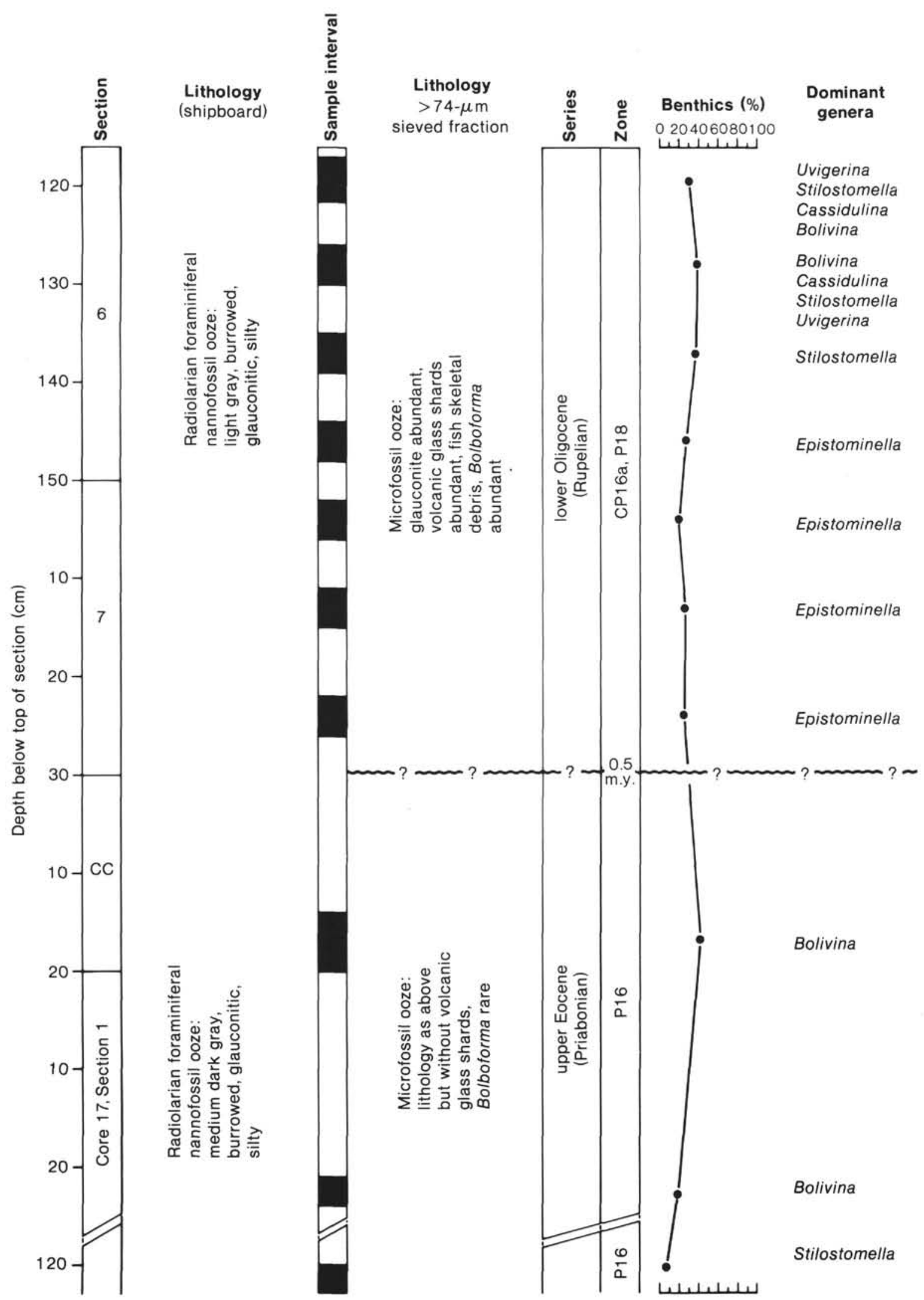

Figure 19. Chart showing lithic and benthic foraminiferal characteristics across the upper Eocene/lower Oligocene contact at Site 612. 
UNCONFORMABLE SEQUENCE BOUNDARIES, SITE 612

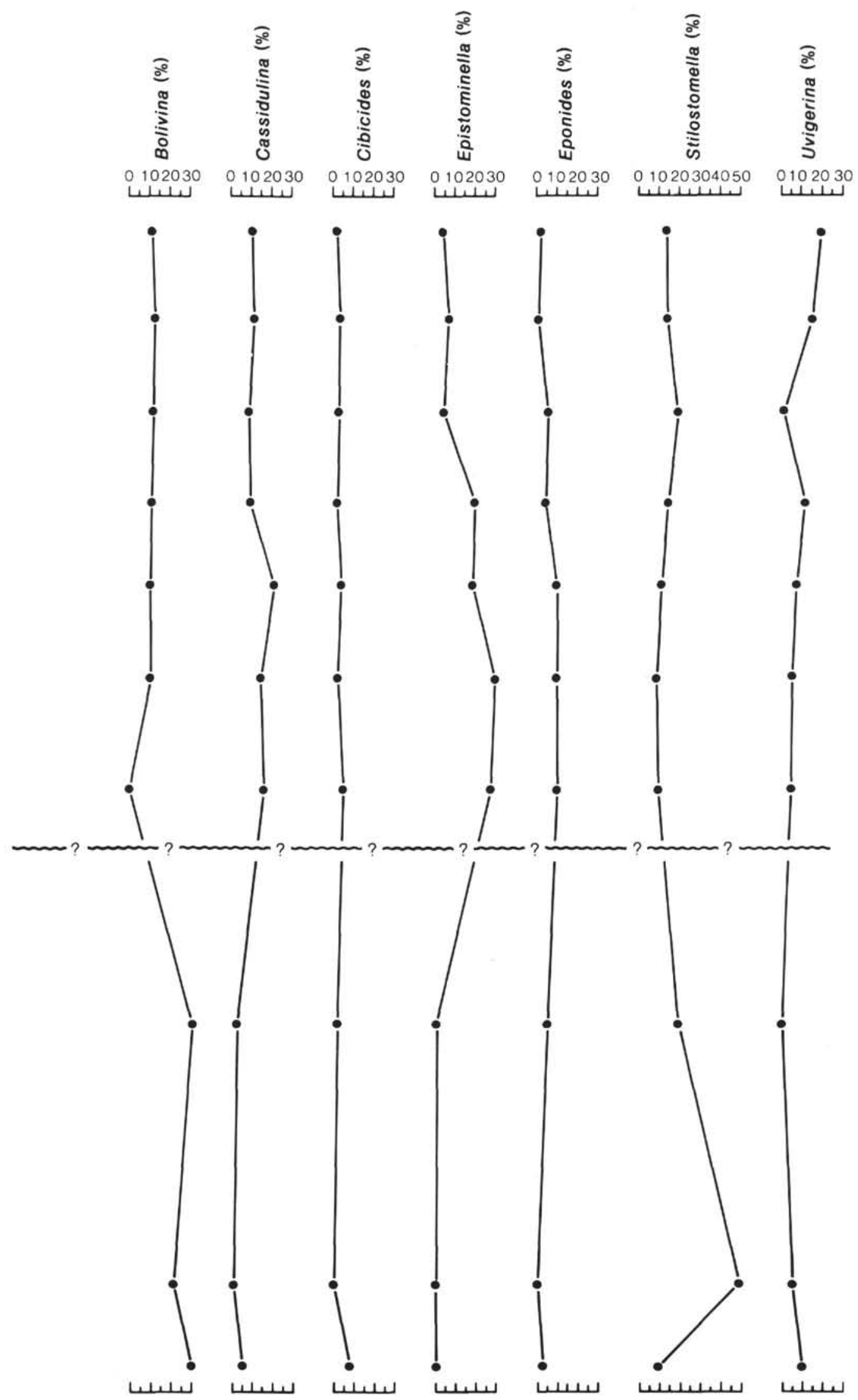

Figure 19 (continued). 
Table 4. Census of benthic foraminiferal genera ( $\%$ of total benthic assemblage $>74 \mu \mathrm{m})$.

\begin{tabular}{|c|c|c|c|c|c|c|c|c|c|c|c|c|c|c|c|c|c|}
\hline \multirow[b]{3}{*}{ Genus } & \multicolumn{17}{|c|}{ Sample interval in $\mathrm{cm}$} \\
\hline & \multicolumn{11}{|c|}{$612-16-6$} & \multicolumn{3}{|c|}{$612-16-7$} & \multirow{2}{*}{$\begin{array}{c}\begin{array}{c}612 . \\
16, \mathrm{CC}\end{array} \\
\text { bottom }\end{array}$} & \multirow{2}{*}{$\begin{array}{l}\frac{612-}{17-1} \\
20-22\end{array}$} & \multirow{2}{*}{$\begin{array}{c}\begin{array}{c}612- \\
17-2\end{array} \\
120-124\end{array}$} \\
\hline & $58-62$ & $67-71$ & $75-80$ & 84-88 & $92-96$ & $101-105$ & $112-114$ & $117-121$ & $126-130$ & $135-139$ & $144-148$ & $2-6$ & $11-15$ & $22-26$ & & & \\
\hline Bolivina & 3.6 & 5.0 & 3.2 & 4.2 & 3.1 & 9.3 & $-^{a}$ & 11.4 & 12.6 & 12.7 & 5.1 & 4.4 & 5.1 & - & 30.0 & 22.4 & 32.0 \\
\hline Cassidulina & 10.3 & 9.3 & 6.0 & 8.2 & 3.4 & 9.7 & - & 12.4 & 13.6 & 8.9 & 10.2 & 16.9 & 14.3 & 16.6 & 2.0 & 0.6 & 4.8 \\
\hline Cibicides & 5.5 & 9.3 & 7.1 & 11.8 & 6.5 & 4.8 & - & 1.7 & 2.4 & 2.2 & 1.4 & 2.4 & 1.3 & 2.1 & 1.7 & - & 2.1 \\
\hline Epistominella & 1.2 & 0.3 & 2.8 & 0.3 & 3.4 & 4.8 & - & 4.3 & 8.2 & 5.4 & 20.4 & 19.6 & 30.5 & 28.4 & - & - & - \\
\hline Eponides & 32.2 & 25.1 & 32.7 & 24.8 & 22.6 & 16.1 & - & 1.4 & 1.0 & 4.8 & 4.2 & 8.4 & 9.5 & 8.9 & 5.1 & 0.3 & 1.8 \\
\hline Stilostomella & 13.1 & 16.4 & 12.5 & 24.2 & 16.1 & 18.5 & - & 15.4 & 13.6 & 18.8 & 15.0 & 12.8 & 8.6 & 11.6 & 16.9 & 59.0 & 9.3 \\
\hline Uvigerina & 3.3 & 2.5 & 3.2 & 1.8 & 1.1 & 6.9 & - & 17.1 & 13.6 & 1.0 & 11.3 & 8.1 & 4.1 & 3.9 & - & 7.1 & 9.0 \\
\hline Alabamina & - & - & - & - & - & - & - & 2.9 & 3.1 & 8.3 & 3.9 & - & 0.6 & - & 3.4 & 1.3 & 3.0 \\
\hline Astrononion & $=$ & $=$ & $=$ & $\overline{-}$ & $=$ & $z$ & $=$ & - & - & - & - & $=$ & - & 1.3 & - & - & - \\
\hline Bulimina & 0.9 & 1.2 & 1.4 & 0.9 & 1.1 & 4.0 & - & 4.8 & 6.1 & 2.9 & 4.2 & 4.4 & 2.5 & 3.7 & 24.7 & 4.8 & 10.2 \\
\hline Buliminella & 0.3 & - & - & - & 0.3 & - & - & 0.7 & 2.0 & 3.5 & - & 1.4 & 4.4 & - & - & 1.3 & 4.2 \\
\hline Candeina & 0.6 & - & 1.1 & - & 4.2 & 0.8 & - & - & - & - & - & - & - & - & - & & \\
\hline Dentalina & - & - & - & - & - & - & - & - & - & 0.3 & - & - & - & - & - & 1.0 & $\underline{-}$ \\
\hline Eggerella & - & - & - & - & - & 0.4 & - & - & $=$ & 0.3 & - & - & - & 2.1 & - & - & - \\
\hline Fissurina & 0.3 & 1.9 & 1.8 & 1.2 & 1.4 & 0.8 & - & 0.2 & 0.3 & 0.3 & - & 0.7 & 1.0 & 0.5 & 0.7 & 0.3 & 0.6 \\
\hline Florilus & - & - & - & - & 0.8 & - & - & - & - & - & - & - & - & 1.6 & - & 0.3 & - \\
\hline Fursenkoina & 1.5 & 1.2 & 1.8 & 0.6 & 2.8 & 1.2 & - & - & - & - & - & - & - & - & - & - & - \\
\hline Gaudryina & - & - & - & 0.3 & - & - & - & - & - & - & - & - & - & - & - & - & - \\
\hline Gavelinella & - & - & - & - & - & - & - & - & - & - & - & - & - & - & 0.3 & - & - \\
\hline Glabratella & - & - & - & - & - & - & - & 0.2 & - & - & - & - & - & - & - & - & - \\
\hline Glandulina & - & - & - & - & 1.1 & - & - & - & - & - & - & - & - & - & - & - & - \\
\hline Globobulimina & - & 0.6 & - & 0.3 & 1.1 & 0.4 & - & - & - & 0.3 & - & - & - & - & - & - & - \\
\hline Globulina & - & - & - & - & - & 0.4 & - & - & - & 0.6 & - & - & 0.3 & - & - & - & - \\
\hline Guttulina & - & - & - & - & - & 0.8 & - & 0.7 & 0.7 & 0.6 & - & 0.3 & - & - & 0.7 & - & - \\
\hline Gyroidina & 1.8 & 2.2 & 0.4 & 0.9 & - & 2.8 & - & 3.8 & 4.1 & 6.1 & 3.4 & 3.7 & 7.0 & 6.8 & 2.0 & - & 2.4 \\
\hline Heronallenia & -8 & -2 & -0.4 & -0 & $\bar{z}$ & 2.8 & $=$ & - & ${ }_{-}^{4.1}$ & - & -3.4 & -3.1 & - & - & -2.0 & $=$ & 0.3 \\
\hline Hoeglundina & $=$ & - & $=$ & $=$ & - & 1.2 & $=$ & $=$ & - & $=$ & $=$ & - & - & - & - & - & - \\
\hline Lagena & 2.7 & 3.7 & 3.2 & 2.4 & 2.8 & 0.8 & - & 1.9 & 0.3 & 1.0 & 0.3 & 1.7 & 1.0 & 0.8 & 1.0 & - & - \\
\hline Lenticulina & 0.9 & 0.3 & 0.7 & 0.6 & 0.8 & 1.2 & - & 1.4 & - & 0.3 & - & - & 1.0 & 1.3 & - & - & 0.6 \\
\hline Loxostomum & - & - & - & - & - & - & - & - & - & - & - & - & - & - & 1.0 & - & 0.3 \\
\hline Martinottiella & 5.1 & 8.0 & 6.0 & 3.6 & 5.1 & 4.4 & - & 0.2 & - & 0.3 & 0.3 & - & - & 0.3 & - & - & - \\
\hline Melonis & 1.2 & 3.1 & 0.7 & 1.8 & 3.4 & 0.8 & - & - & - & - & - & 0.7 & - & - & - & - & 0.6 \\
\hline Neobulimina & - & - & - & - & - & - & - & - & - & 2.0 & - & - & - & - & - & - & - \\
\hline Nodosaria & - & - & - & - & - & - & - & - & - & 0.3 & - & - & - & - & 1.4 & - & - \\
\hline Nonionella & 6.7 & 0.9 & 6.4 & 3.3 & 3.1 & 1.6 & - & 4.0 & 4.8 & 5.7 & 2.3 & 2.7 & 2.2 & - & - & - & - \\
\hline Nuttallides & - & - & - & - & - & - & - & 2.9 & 3.1 & 3.2 & 3.1 & 0.7 & - & - & - & 0.3 & 8.47 \\
\hline Oolina & - & - & - & - & - & - & - & - & - & 0.3 & - & - & - & - & - & - & - \\
\hline Oridorsalis & - & - & - & - & - & 1.2 & - & 1.9 & 0.3 & - & - & - & - & - & - & - & 0.3 \\
\hline Orthomorphina & 0.6 & 1.9 & 2.1 & 3.6 & 9.3 & - & - & - & - & - & - & - & - & - & - & - & - \\
\hline Osangularia & - & - & - & - & - & - & - & 4.3 & 1.7 & 2.5 & 4.0 & 3.0 & 2.2 & 3.7 & 2.7 & - & - \\
\hline Parafissurina & 1.5 & - & - & - & - & $=$ & - & - & - & - & - & - & - & - & - & - & - \\
\hline Plectofrondicularia & 0.6 & 1.9 & 1.4 & 0.3 & 0.6 & 1.6 & - & 0.2 & 0.3 & 2.2 & 0.3 & 0.7 & - & - & 1.0 & - & - \\
\hline Pleurostomella & 1.2 & 1.2 & 0.4 & 0.3 & 0.8 & 0.8 & - & 0.2 & - & 0.3 & - & 0.7 & - & $=$ & - & 1.0 & 0.6 \\
\hline $\begin{array}{l}\text { Pullenia } \\
\text { Pal }\end{array}$ & 2.4 & 1.9 & 2.1 & 2.7 & 4.2 & 1.6 & - & 5.5 & 7.1 & 6.4 & 4.2 & 5.1 & 2.5 & 1.8 & 8.1 & - & - \\
\hline Pyrgo & 0.3 & - & - & - & - & - & - & - & - & - & - & - & - & - & - & - & - \\
\hline Quadrimorphina & - & 0.9 & 1.8 & - & 0.6 & 0.8 & - & - & - & - & - & - & - & - & - & - & 0.6 \\
\hline Quinqueloculina & 0.3 & 0.9 & - & - & - & 0.4 & - & 0.2 & - & - & - & - & 0.3 & 0.3 & 0.3 & - & - \\
\hline Sigmoilops: & - & 0.3 & 0.4 & - & - & - & - & - & - & - & - & - & - & - & - & - & - \\
\hline Spirobolivina & - & - & 0.4 & - & - & - & - & - & - & - & - & 0.3 & - & - & - & - & - \\
\hline Suggrunda & - & - & - & - & - & - & - & - & 1.0 & 1.9 & 1.4 & 1.4 & 1.3 & - & - & - & - \\
\hline Textularia & - & - & 0.4 & 0.3 & - & - & - & 0.2 & - & - & - & - & - & - & - & 0.3 & 0.3 \\
\hline Dritaxia & - & - & - & - & - & - & - & - & - & - & - & - & - & - & - & - & 0.3 \\
\hline Turrilina & - & - & - & - & - & - & - & - & - & - & - & - & - & - & - & - & 0.9 \\
\hline Vaginulina & - & - & - & - & $=$ & - & - & - & - & - & - & - & 0.3 & 0.3 & - & - & - \\
\hline Valvulineria & 1.5 & - & - & 0.6 & - & - & - & - & - & - & - & - & - & - & - & - & - \\
\hline Vulvulina & - & - & - & 0.9 & $=$ & $\overline{-}$ & - & - & - & - & - & - & - & - & - & - & - \\
\hline Total specimens & 329 & 323 & 281 & 331 & 354 & 248 & 0 & 421 & 294 & 314 & 353 & 296 & 315 & 380 & 295 & 312 & 334 \\
\hline \% Benthics & 44 & 52 & 47 & 60 & 93 & 47 & 0 & 28 & 34 & 35 & 27 & 18 & 23 & 23 & 38 & 18 & 11 \\
\hline No. benthic genera & 26 & 24 & 25 & 25 & 26 & 28 & 0 & 26 & 21 & 25 & 24 & 22 & 21 & 21 & 19 & 14 & 23 \\
\hline
\end{tabular}

a - means not present.

dominated by four genera (Bolivina, Cassidulina, Stilostomella, and Uvigerina) which persists to the unconformable contact. Above the nonfossiliferous sand, Eponides predominates in most samples (16-33\%), but Stilostomella is copredominant in two.

Several other distinct abundance changes take place among individual genera. Epistominella and Eponides, for example, have reciprocal trends. Epistominella is most abundant in the lowest two samples (28-31\%), declines progressively upward to the contact $(4.3 \%)$, and remains sparse above the sand $(0.3-4.8 \%)$. Eponides, on the other hand, is sparse $(1.0-9.5 \%)$ below the contact, increases to $16 \%$ just above the sand, and reaches more than $25 \%$ in the highest three samples analyzed. The trend of Cassidulina is similar to that of Epistominella although at lower values; Cibicides is similar to Eponides (also at lower values). The relative abundance of Stilostomella is rather constant, except for its absence in the sand.

The two oxygen-sensitive genera, Bolivina and Uvigerina, have parallel trends, being generally rather sparse, but increasing between $612-16-6,139 \mathrm{~cm}$ and the contact. This suggests that oxygen levels may have decreased slightly in the early Oligocene prior to the erosion.

The number of benthic genera ranges from 21 to 26 below the contact (mean 22.8) and from 24 to 28 above the contact (mean 25.6). There probably is little meaningful difference in these values.

The long hiatus (25 m.y.) separating the Rupelian and Tortonian sections at Site 612 encompassed a well-documented period of significant evolutionary change among 


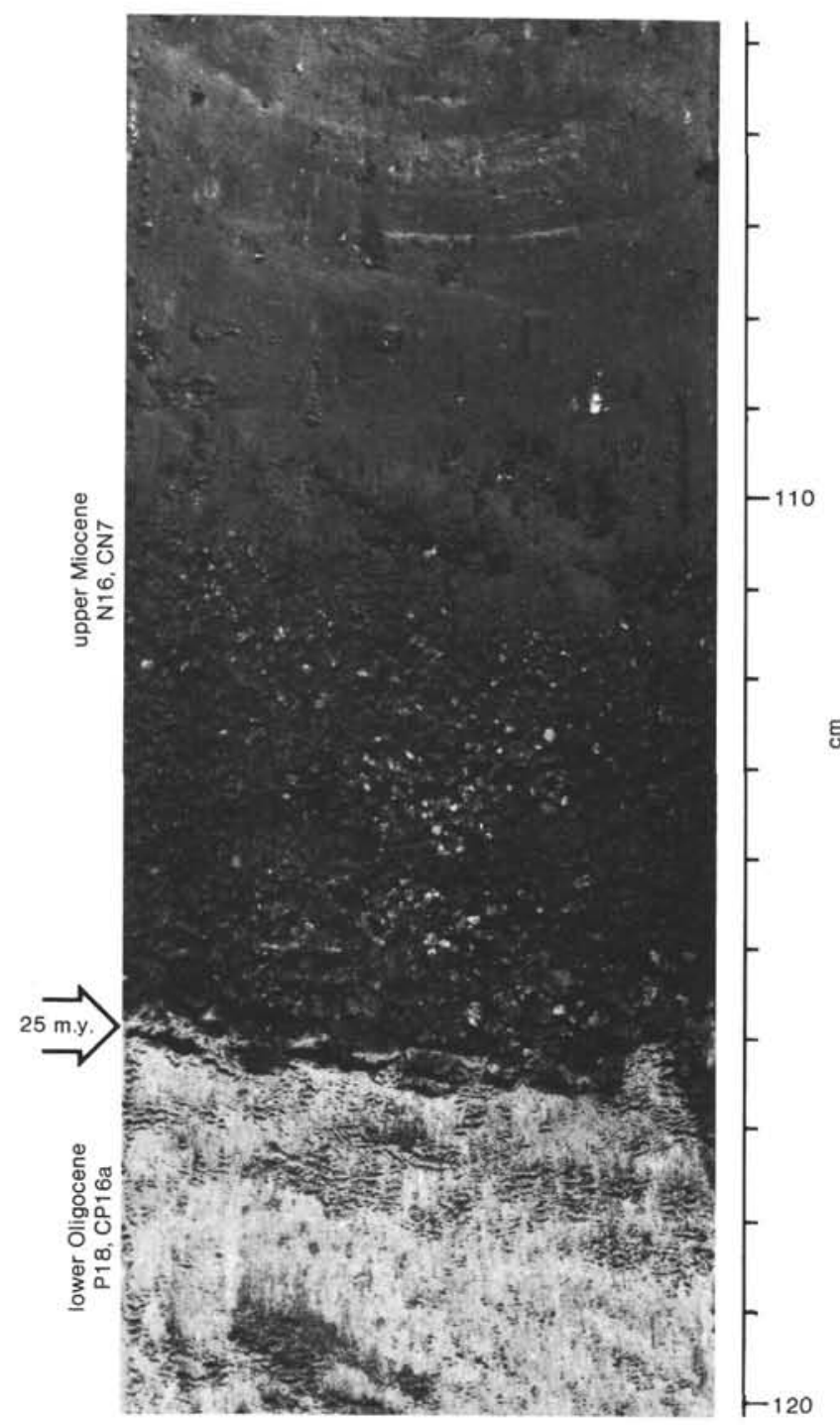

Figure 20. Photograph of the unconformable contact between the lower Oligocene and upper Miocene sequences at Site 612 (Section 612-16-6).

benthic foraminifers (Douglas, 1979; Douglas and Woodruff, 1981; Woodruff and Douglas, 1981; Berggren and Schnitker, 1983) as the Neogene-modern fauna replaced that of the Paleogene. Some of the assemblage changes documented here, therefore, may be accounted for, in part, by evolution, and not by paleoenvironmental shifts alone.

\section{Interpretation}

During the Oligocene, a prograding shelf edge moved the "inner" shelf break $12 \mathrm{~km}$ seaward to shotpoint 1000 (Line 25; Fig. 7). Erosion across the "outer" middle Eocene shelf break has eliminated evidence of an "outer" Oligocene shelf break, if one were present at all. Bathyal depths $(\sim 1000 \mathrm{~m})$ at Site 612 are indicated by the high percentage of planktonic foraminifers, the predominance of Epistominella among the benthic foraminifers, and by the accompanying benthic assemblage. This is in agreement with the lower bathyal paleodepth estimated at the COST B-3 and ASP 15 sites (Poag, $1980,1985 a)$. The seafloor must have been well-oxygenated (light colored sediment; low total organic carbon [Stein et al., this volume]) but a slightly lowered oxygen level near the end of the early Oligocene deposition is suggested by the increase in Bolivina and Uvigerina. Only sparse terrigenous debris reached the site (chalk lithology), but distant volcanism is recorded by the enrichment in volcanic ash. Surface waters were fertile, as indicated by the abundance of radiolarians, and perhaps by the abundance of Bolboforma which is thought to have been a constituent of the phytoplankton (Rögl and Hochuli, 1976). The paleoslope model cannot be used to estimate paleobathymetry at Site 612 because lower Oligocene sediments are not known with certainty from the coastal plain of New Jersey and because Site 612 at this time occupied a continental slope position.

During the 25-m.y. hiatus represented by the unconformity, a series of erosional and depositional episodes took place in the vicinity of Site 612 as evidenced by drilling nearby on the upper slope (Sites ASP 14, 15, and COST B-3) and on the shelf and coastal plain (Ward, 1984; Poag, 1985a; Ward and Strickland, 1985). Of particular note is a thick deltaic sequence of mud and sand that prograded across the shelf and reached within a few kilometers of Site 612 during the middle Miocene (240 $\mathrm{m}$ of middle Miocene silt and mud are present at ASP $14 ; 200 \mathrm{~m}$ at COST B-3; Poag, 1985a). It is not surprising that redeposited middle Miocene planktonic foraminifers are present, as noted above, in the Tortonian section at Site 612. In fact, middle Miocene sediments probably accumulated at Site 612 (they are present at ASP 15), but were removed by late Miocene channeling that created the Rupelian-Tortonian unconformity (highresolution seismic profiles clearly show that Site 612 was drilled within a shallowly buried Miocene channel [Farre, 1985; Poag and Mountain, this volume]).

Following the erosion that created the unconformity, deposition resumed in the Tortonian at Site 612, as a thin turbidite sand, followed by terrigenous, micaceous muds, filled the channel. Radiolarians dominate the testate microfossils in the Tortonian section, giving evidence of continued rich nutrient sources in the surficial water masses. Poag (1980, 1985a), and Palmer (1983) showed that upwelling combined with a peridelta environment to produce a particularly fertile surface water mass in this region during the Miocene. Continued seaward progradation of the late Miocene deposits constructed a pronounced shelf break at about shotpoint 2600 (Line 25) (Fig. 7); Site 612 was located on the lower continental slope in lower bathyal water depths (1000-2000 m). The predominance of Eponides and Stilostomella may reflect a greater water depth than that of the early Oligocene Epistominella assemblages. Poag (1985a) estimated upper bathyal paleodepths for middle-to-late Miocene deposition at the COST B-3 well site and lower bathyal paleodepths at ASP 14 and 15.

\section{Regional Relationships}

The Rupelian/Tortonian contact at Site 612 juxtaposes supersequences $\mathrm{Tc}$ and $\mathrm{Te}$ of the Vail depositional model 


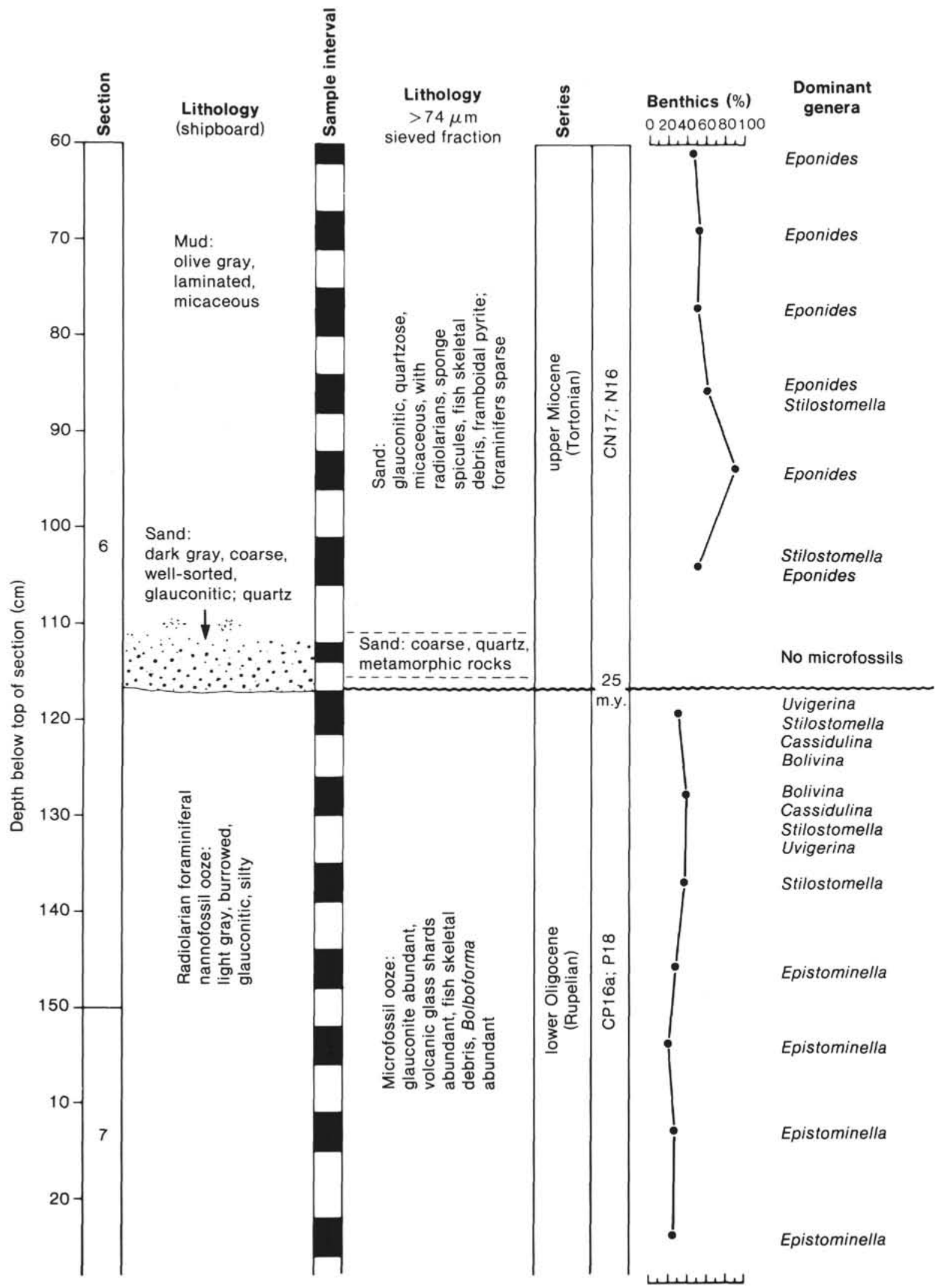

Figure 21. Chart showing the lithic and benthic foraminiferal characteristics across the lower Oligocene/upper Miocene contact at Site 612. 
UNCONFORMABLE SEQUENCE BOUNDARIES, SITE 612

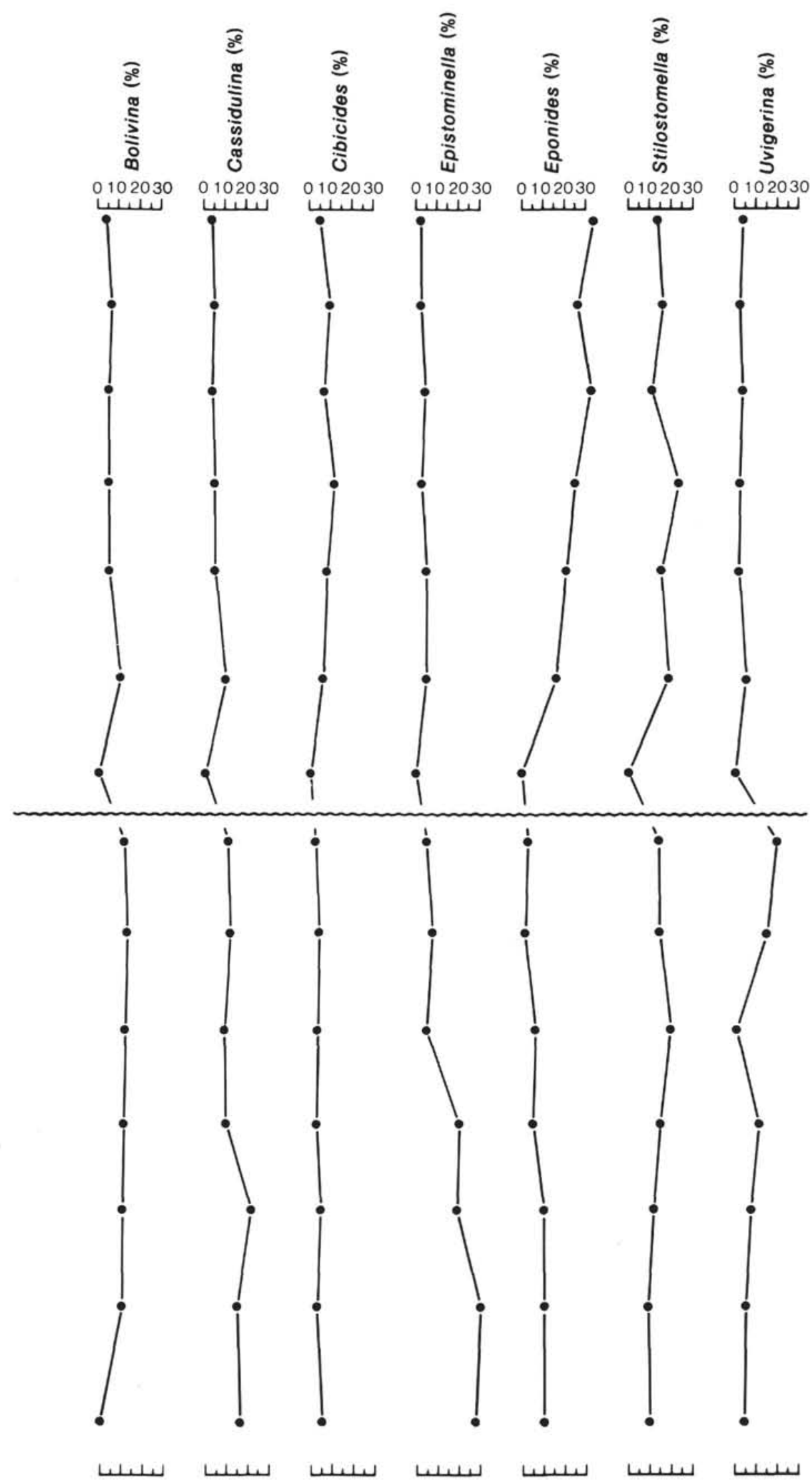

Figure 21 (continued). 
(Vail and Mitchum, 1979). Supersequence Td and most of Te are not represented. This part of the stratigraphic column at Site 612 is, however, not representative of the late Paleogene-early Neogene depositional regimes of the New Jersey slope, because upper Oligocene, lower Miocene, and middle Miocene strata (supersequences Td and $\mathrm{Te}$ ) are well represented in surrounding sections (e.g., COST B-3 well; $300 \mathrm{~m}$ thickness; P21b-N14). These Oligocene and Miocene units can also be traced widely on seismic reflection profiles (Hampson and Robb, 1984; Farre, 1985; Poag, 1985a). The seismic reflections that bound each of these supersequences coalesce into the single reflector that marks the channel thalweg at Site 612. However at ASP 15 , only $6 \mathrm{~km}$ along strike to the southwest, $40 \mathrm{~m}$ of lower Miocene and middle Miocene (N13-14) strata are present, and at ASP 14 these units are even thicker ( $\sim 250 \mathrm{~m}$; N6-N12[?]). Thus the major channel cutting at Site 612 appears to have taken place during the early Tortonian (post N14, as documented at ASP 15 and COST B-3; pre-N16, as documented at Site 612 ), when the seaward edge of the middle Miocene delta was truncated as a result of lowered sea level (Poag, 1985a). The channeling presumably represents part of a global period of erosion, which, according to Vail and Mitchum (1979), coincided with the N15-16 boundary at $9.8 \mathrm{Ma}$; Berggren et al. (1985) date this boundary at 11.1 Ma. Prior to this however, a major period of erosion in the late Oligocene removed most of the lower Oligocene strata from the coastal plain, shelf, and slope (Poag and Schlee, 1984; Poag, 1985a; Ward and Strickland, 1985). This mid-Oligocene period of erosion has also been documented on the Goban Spur (Poag et al., 1985), off North Carolina (Popenoe, 1985), and in Australia (McGowran, 1979; Quilty, 1980). Recently published oxygen-isotope analyses show that a significant increase in the global ice volume was associated with this unconformity (Keigwin and Keller, 1984; Miller et al., 1985).

\section{TORTONIAN/MESSINIAN CONTACT}

\section{Lithologic Characteristics}

The contact between Tortonian and Messinian strata at Site 612 is manifested by a fractured scour surface in 612-13-6, $93 \mathrm{~cm}$, which separates two distinctly different muddy lithologies (Figs. 22, 23). Below the contact is a light olive gray, micaceous, homogeneous mud; above is a dark olive gray, micaceous mud, containing layers and scattered patches of glauconite sand. A 2-cm bone fragment, surrounded by glauconite sand, is present in 612 $13-6,81-83 \mathrm{~cm}$. The contact is disturbed by a diagonal fracture, $5 \mathrm{~cm}$ deep, filled with dark, glauconitic mud derived from the younger section. There is no obvious mixing of sediments across the contact by burrowing.

In the $>74-\mu \mathrm{m}$ sieved fraction, the seven samples below the unconformity (Fig. 23) contain chiefly fine, micaceous, quartz sand and a subordinate amount of fine, dark green, glauconite sand. Lignitized plant fragments and burrow casts made of framboidal pyrite are common. Radiolarians and planktonic foraminifers are abundant throughout the section except in the two samples

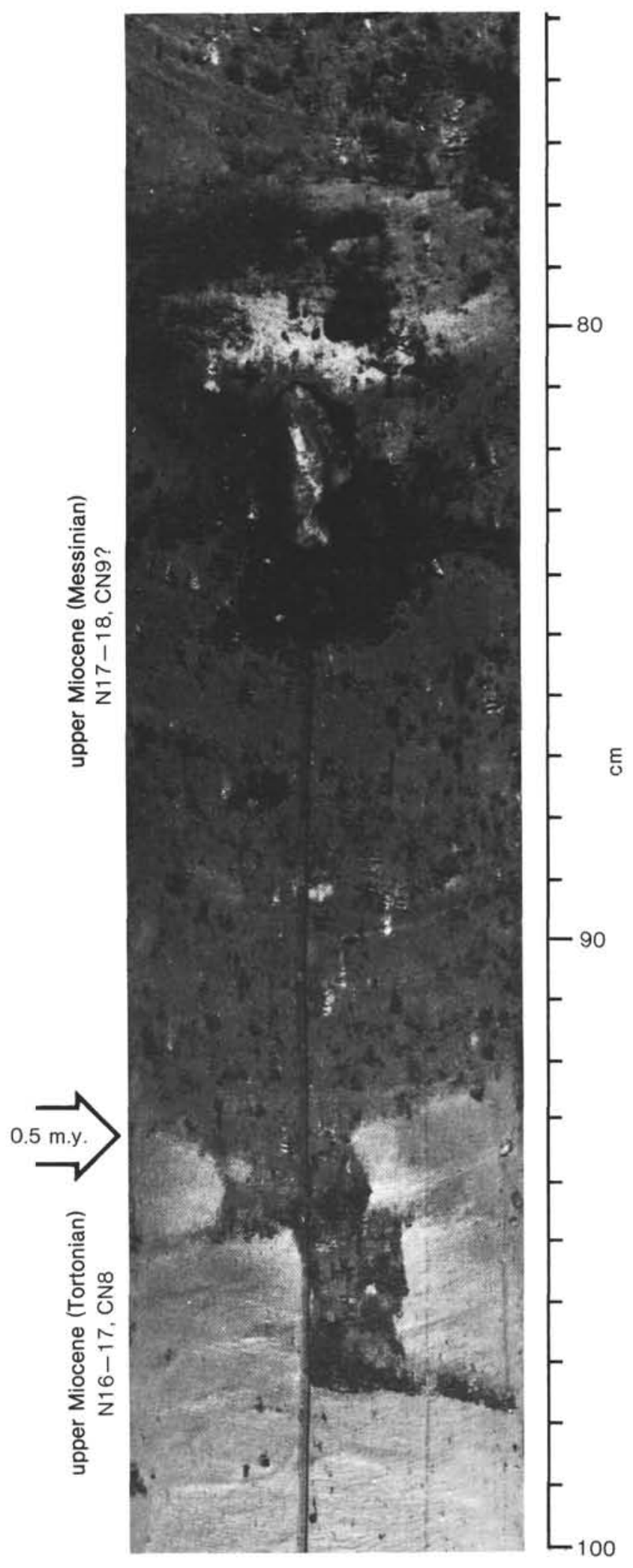

Figure 22. Photograph of the unconformable contact between the Tortonian and Messinian sequences at Site 612 (Section 612-13-6).

closest to the unconformity, where the foraminifers are rare and fragmented.

Above the unconformity, dark green, medium to coarse glauconite sand is the dominant lithic component in the 
$>74-\mu \mathrm{m}$ fraction. A few poorly sorted grains of quartz also are present. Microfossils are dominantly radiolarians, as foraminifers are sparse.

\section{Biochronology}

The planktonic foraminiferal assemblages below the Tortonian/Messinian contact are moderately rich and diverse. The lowest sample $(612-13-6,145-149 \mathrm{~cm})$ contains Sphaeroidinellopsis subdehiscens, S. seminulina, Globigerina apertura, G. bulloides, G. quinqueloba, G. praebulloides, Globigerinita glutinata, G. uvula, Orbulina universa, Globigerinoides mitra, G. obliquus, Globorotalia merotumida, G. scitula, G. plesiotumida, and Neogloboquadrina pachyderma. This and a similar, but less diverse, assemblage in Sample 612-13-6, 118-114 cm, may be assigned to Zones N16-17 of the Tortonian Stage (as defined by Kennett and Srinivasan, 1983). In addition to these foraminifers, two radiolarian species, $\mathrm{Di}$ dymocyrtis laticonus and Diartus pettersoni, which do not extend stratigraphically higher than middle Zone N16 (Theyer et al., 1978; Sanfilippo et al., 1985; Berggren et al., 1985; Palmer, this volume), are consistently present below the unconformity.

The six samples immediately above the unconformity (Sample 612-13-6, 40-92 cm) are difficult to date with planktonic foraminifers, which are scarce. However, upper Miocene radiolarians (Diartus hughesi and Didymocyrtis antepenultima), which do not occur lower than upper Zone N16, are consistently present in these samples. The nearest sample above the contact having a datable planktonic foraminiferal assemblage is Sample 612$13-5,120-124 \mathrm{~cm}$ (119 $\mathrm{cm}$ above the contact). The presence there of Sphaeroidinellopsis subdehiscens, S. seminulina, Neogloboquadrina humerosa, N. acostaensis, Globigerina bulloides, $G$. nepenthes, G. incisa, G. falconensis, Globigerinoides conglobatus, G. extremus, Globorotalia cultrata, G. scitula, and Globigerinella obesa, indicates that this sample represents Zone N17-18 of the latest Miocene (Messinian Stage). These combined data indicate, therefore, that a short hiatus of perhaps 0.5 m.y. is represented by the unconformable Tortonian/ Messinian contact.

\section{Geophysical Characteristics}

On the downhole geophysical log, the Tortonian/Messinian contact is marked by higher gamma-ray values in the Messinian section (Fig. 16), probably reflecting the larger quantity of glauconite. Sonic velocity also is greater in the Messinian section, and the velocity change across the unconformity at $\sim 1.99 \mathrm{~s}$ (integrated sonic log) correlates with a moderately strong seismic reflector at the same depth on Line 25 (Fig. 6).

\section{Benthic Foraminiferal Characteristics}

The major microfaunal change associated with the Tortonian/Messinian contact is the dominance of radiolarians and virtual absence of foraminifers between Samples $612-13-6,106-110 \mathrm{~cm}$ (below the contact) and 61213-6, 40-44 cm (above the contact). However, below the contact, several interesting trends can be observed among the benthic foraminifers. The percentage of ben- thic specimens is high throughout, increasing progressively upward from 44 to $92 \%$ (Fig. 23; Table 5). These high values suggest either that planktonic foraminifers have been preferentially dissolved, or that the original assemblage has been altered by the downslope transport of shallower-water forms. The presence of Nonionella and Buccella does suggest some downslope redeposition, but these forms are only minor components of the assemblage.

Among the predominant genera, Eponides is the principal form in the lower two samples (26-30\%). It declines upward, becoming copredominant with Bolivina in the next three samples, finally to become subordinate to $\mathrm{BO}$ livina. The other two common genera, Cassidulina and Stilostomella, display no significant stratigraphic trends, although Cassidulina disappears temporarily in Sample $612-13-6,125-127 \mathrm{~cm}$.

The number of benthic genera varies only slightly throughout the section (range $=23-29$; mean 24.5 ) and is similar to values cited from lower in the section.

\section{Interpretation}

The physiographic position of Site 612 during the Tortonian-Messinian interval was similar to its present location on a lower continental slope (Fig. 7). The general composition of the benthic assemblages suggest that bathyal depths prevailed, but probably were somewhat shallower than today's depth (i.e., the added load of Pliocene and Quaternary sediments on the shelf and upper slope have depressed the seafloor at Site 612 below its late Miocene paleodepth). The paleoslope model cannot be applied for the late Miocene paleodepths, for the site lies seaward of the late Miocene shelf break. Furthermore, this interval is not well known on the New Jersey Coastal Plain (Owens and Sohl, 1969; Jordan and Smith, 1984). The relative paucity of planktonic foraminifers below the contact appears to have been partly the result of diagenetic dissolution, as the site would have been well above the calcite lysocline. Hemipelagic sediments accumulated here in relatively well-oxygenated conditions during the Tortonian, resulting in the homogenization of the mud by burrowing organisms.

Later, as the erosional episode approached, bottom conditions became more oxygen deficient, allowing the opportunistic bolivinids to expand their populations and dominate the benthic foraminifers. An influx of plant fragments just below the unconformity, the dominance of radiolarians, and the disappearance of foraminifers, suggests that fertile surface waters were associated with upwelling and delta progradation (Poag, 1985a).

Following this erosion, deposition resumed with the downslope displacement of coarse glauconitic sands and mud by a debris flow. Continued nutrient enrichment of the surface waters is indicated by the dominance of radiolarians.

\section{Regional Relationships}

The Tortonian/Messinian contact has not been documented previously on the New Jersey shelf and slope. Samples were not collected this high in the section at the COST B-2 and B-3 wells, nor at other commercial well 
C. W. POAG, D. LOW

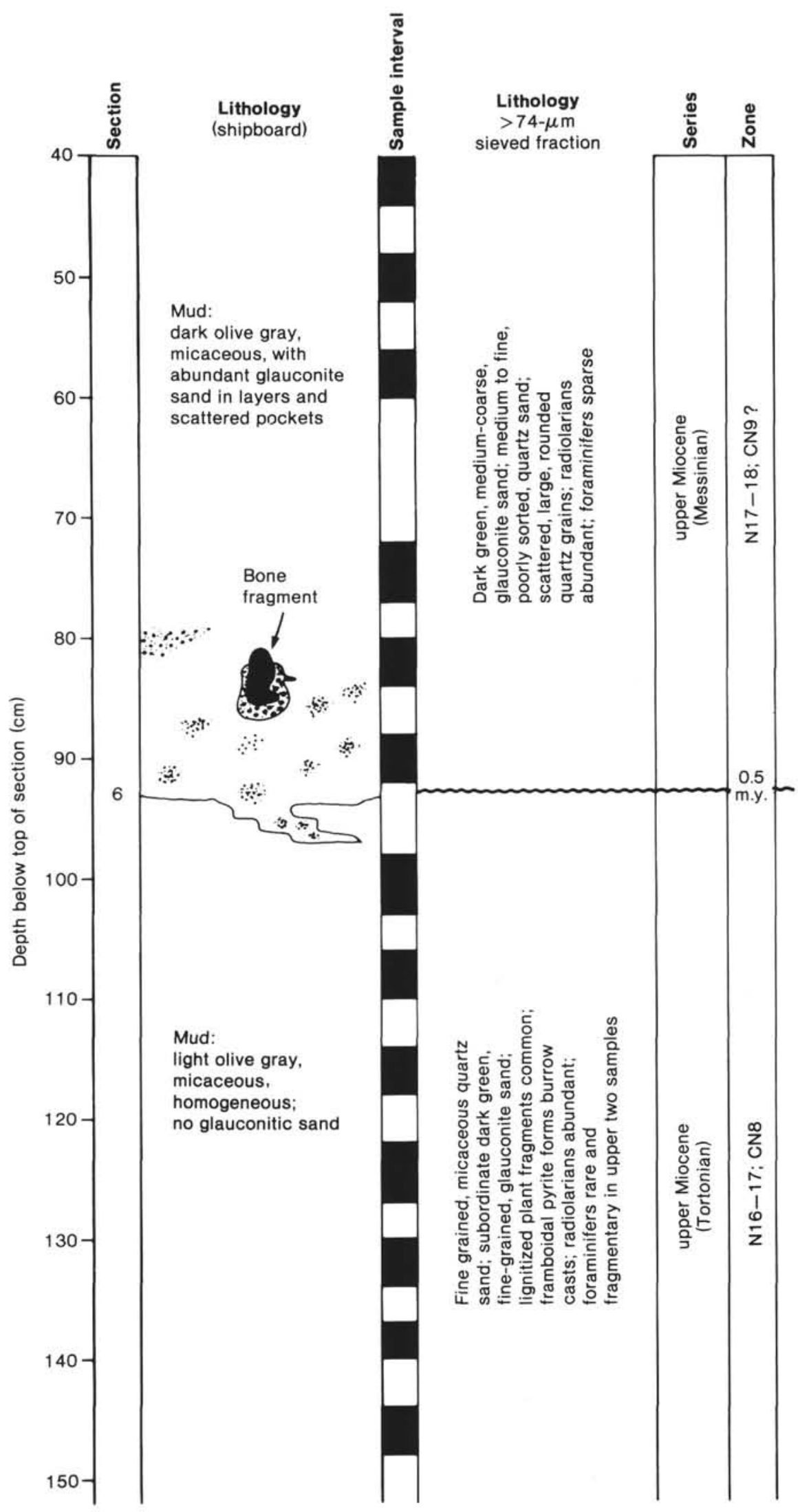

Figure 23. Chart showing lithic and benthic foraminiferal characteristics across the Tortonian/ Messinian contact at Site 612 . 
UNCONFORMABLE SEQUENCE BOUNDARIES, SITE 612

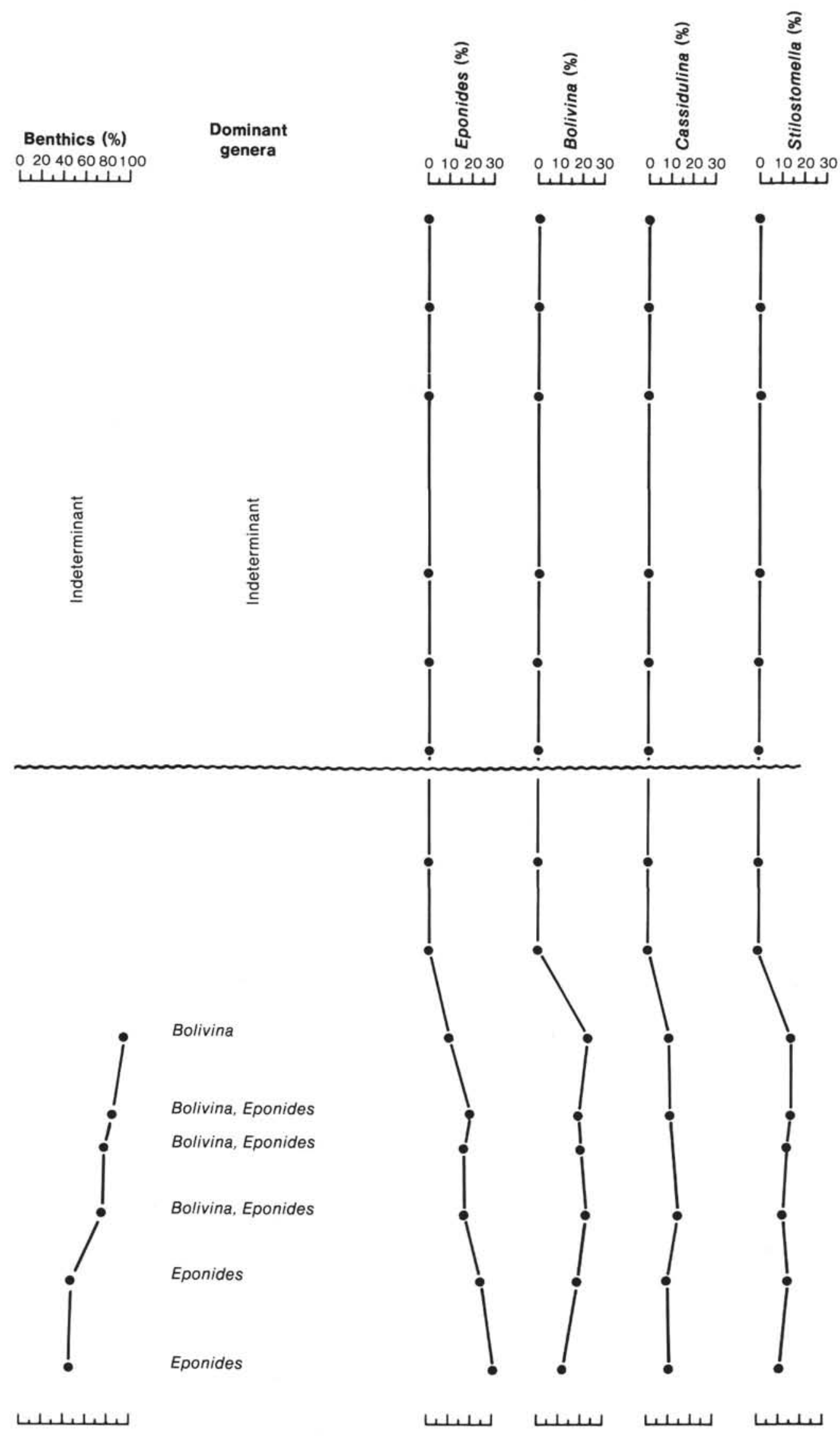

Figure 23 (continued). 
Table 5. Census of benthic foraminiferal genera ( $\%$ of total benthic assemblage $>74 \mu \mathrm{m}$ ).

\begin{tabular}{|c|c|c|c|c|c|c|c|c|c|c|c|c|c|c|}
\hline \multirow[b]{2}{*}{ Genus } & \multicolumn{14}{|c|}{ 612-13-6 (interval in $\mathrm{cm}$ ) } \\
\hline & $40-44$ & $48-52$ & $56-60$ & $72-76$ & $80-84$ & $88-92$ & $99-103$ & $106-110$ & $114-118$ & $122-125$ & $125-127$ & $130-134$ & $137-141$ & $145-149$ \\
\hline Bolivina & $-^{a}$ & - & - & - & - & - & - & - & 23.8 & 18.8 & 19.1 & 21.4 & 18.0 & 11.1 \\
\hline Cassidulina & - & - & - & - & - & - & - & - & 7.9 & 8.9 & - & 13.9 & 7.2 & 8.8 \\
\hline Eponides & - & - & - & - & - & - & - & - & 10.9 & 20.0 & 18.8 & 17.4 & 25.5 & 30.0 \\
\hline Stilostomella & - & - & - & - & - & - & - & - & 14.6 & 14.0 & 12.9 & 10.0 & 13.7 & 8.8 \\
\hline Astrononion & - & - & - & - & - & - & - & - & - & - & - & - & 0.7 & - \\
\hline Buccella & - & - & - & - & - & - & - & - & - & 0.3 & 0.4 & - & - & - \\
\hline Bulimina & - & - & - & - & - & - & - & - & 5.0 & 1.3 & 4.7 & 1.8 & 1.4 & - \\
\hline Cibicides & - & - & - & - & - & - & - & - & 3.0 & 1.6 & 7.0 & 1.8 & 0.4 & 2.2 \\
\hline Dentalina & - & - & - & - & - & - & - & - & - & - & - & 1.1 & - & - \\
\hline Eggerella- & - & - & - & - & - & - & - & - & - & - & 0.4 & - & 0.4 & \\
\hline Ehrenbergina & - & - & - & - & - & - & - & - & - & 1.0 & - & 0.7 & 0.4 & 0.4 \\
\hline Epistominella & - & - & - & - & - & - & - & - & 4.3 & 2.5 & 0.4 & 5.3 & 3.6 & 3.7 \\
\hline Fissurina & - & - & - & - & - & - & - & - & 1.3 & 0.3 & 1.2 & 0.7 & 1.8 & 1.1 \\
\hline Florilus & - & - & - & - & - & - & - & - & 0.7 & 4.8 & 7.0 & - & 3.6 & 1.5 \\
\hline Fursenkoina & - & - & - & - & - & - & - & - & 1.0 & 1.9 & 3.1 & 1.4 & 2.9 & 6.7 \\
\hline Globobulimina & - & - & - & - & - & - & - & - & 1.3 & 3.2 & 0.8 & 1.4 & 1.1 & 2.2 \\
\hline Guttulina & - & - & - & - & - & - & - & - & 0.3 & - & - & - & - & - \\
\hline Gyroidina & - & - & - & - & - & - & - & - & 0.7 & 1.3 & - & 1.4 & 3.6 & - \\
\hline Hoeglundina & - & - & - & - & - & - & - & - & 0.3 & - & - & - & - & - \\
\hline Lagena & - & - & - & - & - & - & - & - & 2.3 & 1.0 & 2.0 & 0.7 & 1.4 & 1.5 \\
\hline Laticarinina & - & - & - & - & - & - & - & - & - & - & - & 0.4 & - & - \\
\hline Lenticulina & - & - & - & - & - & - & - & - & - & - & - & 0.4 & - & - \\
\hline Martinottiella & - & - & - & - & - & - & - & - & 0.3 & 1.3 & 2.3 & 0.4 & 0.4 & 1.9 \\
\hline Melonis & - & - & - & - & - & - & - & - & 3.6 & 2.5 & 3.1 & 2.5 & 2.9 & 6.7 \\
\hline Nodosaria & - & - & - & - & - & - & - & - & 4.0 & 3.8 & 0.3 & 3.2 & 2.5 & 1.9 \\
\hline Nonionella & - & - & - & - & - & - & - & - & 4.3 & 2.5 & 5.9 & 5.3 & 2.2 & 3.0 \\
\hline Oridorsalis & - & - & - & - & - & - & - & - & - & 0.3 & - & 1.1 & 0.7 & - \\
\hline Orthomorphina & - & - & - & - & - & - & - & - & - & - & - & - & - & 1.1 \\
\hline Parafissurina & - & - & - & - & - & - & - & - & - & - & 0.4 & - & - & - \\
\hline Plectofrondicularia & - & - & - & - & - & - & - & - & 3.3 & 1.6 & 2.7 & 1.8 & 1.1 & - \\
\hline Pleurostomella & - & - & - & - & - & - & - & - & 2.0 & 0.6 & 1.2 & 0.4 & - & 0.7 \\
\hline Pullenia & - & - & - & - & - & - & - & - & - & - & 2.7 & 1.1 & 0.4 & 0.7 \\
\hline Robertina & - & - & - & - & - & - & - & - & - & - & 0.4 & 0.7 & - & 0.4 \\
\hline Sigmoilopsis & - & - & - & - & - & - & - & - & - & - & 0.4 & 0.4 & 0.4 & - \\
\hline Uvigerina & - & - & - & - & - & - & - & - & 4.6 & 6.4 & - & 2.1 & 3.6 & 3.3 \\
\hline Valvulineria & - & - & - & - & - & - & - & - & 0.3 & - & 0.4 & 2.1 & 0.7 & 1.5 \\
\hline Total specimens & - & - & - & - & - & - & - & - & 302 & 314 & 256 & 281 & 278 & 270 \\
\hline$\%$ Benthics & - & - & - & - & - & - & - & - & 92 & 81 & 75 & 76 & 49 & 44 \\
\hline No. of benthic genera & - & - & - & - & - & - & - & - & 23 & 23 & 23 & 29 & 26 & 23 \\
\hline
\end{tabular}

a - means not present.

sites. Intermittent coring coupled with long erosional hiatuses prevented its recognition in the shallower boreholes, such as ASP and AMCOR. However, a pronounced seismic reflector, previously interpreted as the Miocene/ Pliocene contact (Poag, 1985a, 1985b) now appears to be more correctly equated with the Tortonian/Messinian unconformity. The unconformity can be traced widely across the New Jersey margin on seismic reflection profiles, and has been described from outcrops and boreholes on the Atlantic Coastal Plain, where it separates the Tortonian Eastover Formation from the Pliocene Yorktown Formation (Ward and Blackwelder, 1980; Ward, 1984; Ward and Strickland, 1985). An equivalent unconformity is known from the nearshore region of North Carolina (Riggs, 1984), from the deeper Georgia-North Carolina margin (Popenoe, 1985), and from coastal plain localities in northern and southern Florida (Adams et al., 1977). Further evidence of widespread erosion during this period comes from the Mediterranean region (Hsü et al., 1977; Adams et al., 1977), the continental slope of Ireland (Poag and Low, 1985), New Zealand (Loutit and Kennett, 1981a, 1981b), Australia (McGowran, 1979; Quilty, 1980), and Puerto Rico (Seiglie and Moussa, 1984).
The Tortonian-Messinian unconformity correlates with a sea-level fall and major global unconformity in the middle of supersequence Tf of the Vail depositional model, which Vail and Mitchum (1979) place at 6.6 Ma, in the middle of foraminiferal Zone N17. Berggren et al. (1985) place this level at 6.4 Ma. The sea-level fall is especially notable for having contributed to the closing of the Straits of Gibraltar and the ensuing evaporation of Mediterranean waters (Messinian "salinity crisis"; Hsü et al., 1977), which profoundly affected global paleoclimates and oceanic circulation patterns in the late Miocene (e.g., Poag and Low, 1985).

\section{UPPER PLIOCENE/UPPER PLEISTOCENE CONTACT}

\section{Lithologic Characteristics}

The unconformable contact of upper Pliocene and upper Pleistocene strata was recovered in $612-5-3,39 \mathrm{~cm}$ (Figs. 24, 25). Below a concave scour surface, the sediment is a homogeneous dark gray mud, containing scattered layers, clumps, and burrow casts of glauconite sand. Immediately above the contact is a 4-cm zone of coarse, dark green to black, glauconite sand, mixed with chunks 


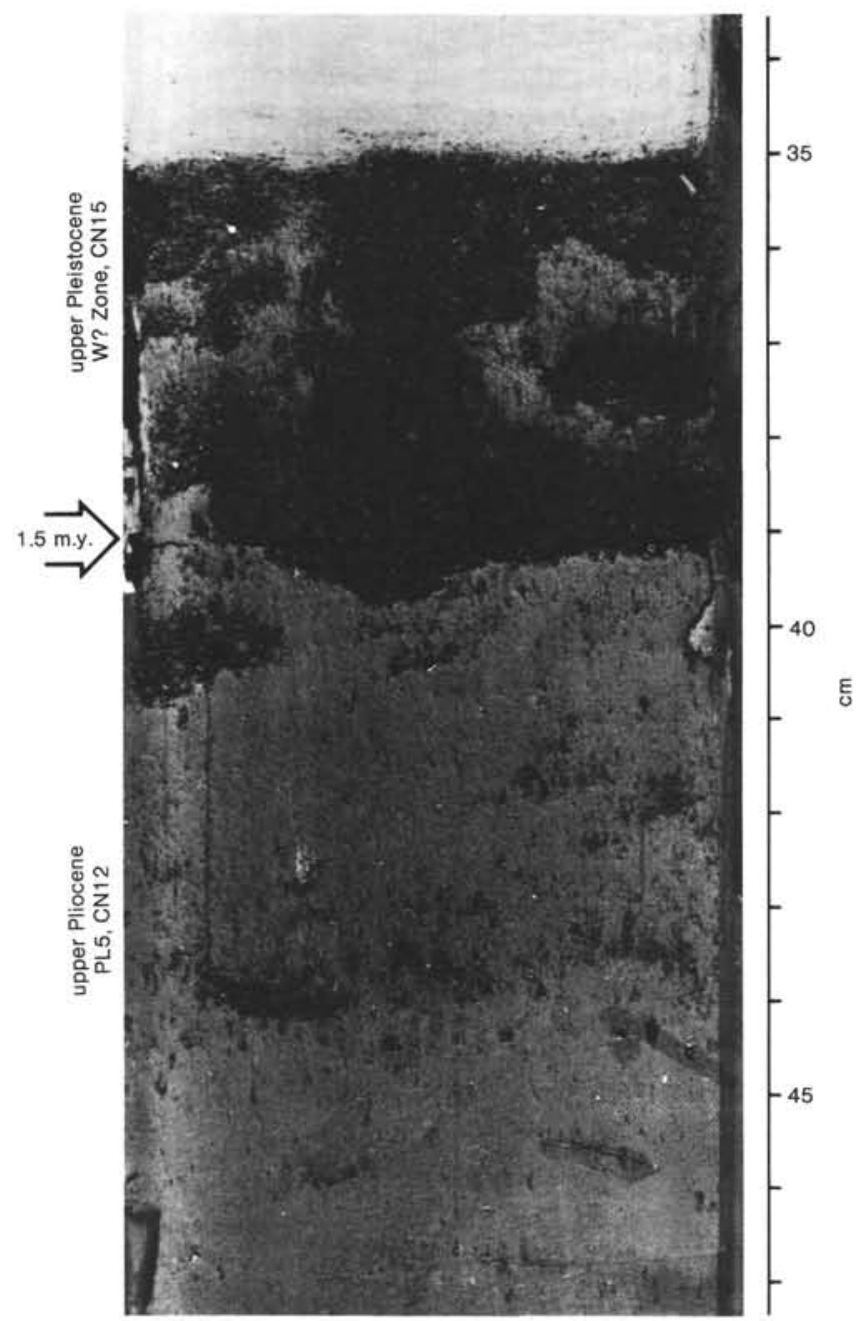

Figure 24. Photograph of the unconformable contact between the upper Pliocene/upper Pleistocene sequences at Site 612 (Sample 6125-3).

of the underlying mud. Above the sand, separated by a sharp contact, is a lighter gray, finely laminated mud.

The $>74-\mu \mathrm{m}$ sieved fraction reveals a much more complicated succession of lithologies (Fig. 25). The lower section (612-5-3, 48-124 cm) consists of slightly micaceous, quartzose, glauconite sand. Small aggregates of gypsum (no euhedral crystals) are rare and foraminifers are rare to common. The sample immediately below the contact (Sample 612-5-3, 40-44 cm) is quite different; quartz sand is dominant, gypsum aggregates are abundant, and foraminifers are rare. Above the contact (Sample 612-5-3, $35-39 \mathrm{~cm}$ ), the residue is quartzose glauconite sand, with only sparse gypsum aggregates and rare foraminifers. The next higher sample $(612-5-3,26-30 \mathrm{~cm})$ contains chiefly quartz sand, glauconite, mica, and gypsum; foraminifers are rare. The youngest section (612-5-3, 0-24 cm and $612-5-2,120-150 \mathrm{~cm}$ ) is principally micaceous quartz sand, frequently containing burrow casts of framboidal pyrite. Glauconite is rare, and foraminifers range from few to common.

\section{Biochronology}

This contact was originally dated on the basis of closely spaced nannofossil samples (see Site 612 chapter, this volume). Planktonic foraminiferal assemblages are sporadically and incompletely represented in many of the samples in this section, but a few moderately rich assemblages corroborate the late Pliocene and late Pleistocene dates derived from nannofossils. In Sample $612-5-3,120-124 \mathrm{~cm}$, an assemblage containing Globigerinoides ruber, G. conglobatus, G. trilobus, Globigerina inflata, G. incisa, G. bulloides, Orbulina universa, Globigerina glutinata, Neogloboquadrina pachyderma, Globorotalia crassaformis, G. scitula, Sphaeroidinella dehiscens, and Sphaeroidinellopsis seminulina is present. The co-occurrence of $S$. seminulina and $G$. inflata indicate that this assemblage belongs to Zone PL5 of the late Pliocene. A similar assemblage in Sample $612-5-3,74-78 \mathrm{~cm}$ contains, in addition, Globorotalia miocenica, corroborating the assignment to Zone PL5, which spans 3-2.1 Ma.

Above the contact, the most complete planktonic assemblage is present in Sample 612-5-2, 120-124 cm; it includes Globigerinoides ruber (pink form), G. conglobatus, Globigerina inflata, G. bulloides, G. rubescens, Globorotalia flexuosa, G. hirsuta, G. truncatulinoides, Neogloboquadrina dutertrei, Pulleniatina obliquiloculata, and Globigerinella aequilateralis. This is a typical late Pleistocene assemblage. The most notable element is the abundance of Globorotalia flexuosa, and its predominance among the globorotaliids. These characteristics are generally diagnostic of the Globorotalia flexuosa Zone (Kennett and Huddelstun, 1972; Poag and Valentine, 1976), which is equivalent to the X Zone of Ericson and Wollin (1968) and Stage 5 of the oxygen-isotope chronology (Berggren et al., 1980). The interval between the G. flexuosa Zone and the unconformity contains a glacial planktonic assemblage dominated by $G$. inflata and $N$. pachyderma and probably belongs to isotopic Stage 6. Oxygen-isotope Stage 5 spans the interval of 0.09$0.12 \mathrm{Ma}$. The nannofossil evidence places this Pleistocene section at no older than $0.44 \mathrm{Ma}$. These data indicate, then, that a hiatus of approximately 1.5-2 m.y. separates the upper Pliocene from the upper Pleistocene section at Site 612.

\section{Geophysical Characteristics}

The upper Pliocene-upper Pleistocene contact at Site 612 is too close to the seafloor to have been logged. The end of the drill pipe had to remain within the hole below the top of the Miocene section during logging. However, the contact forms a distinct reflector on high-resolution seismic lines and can be traced widely across the New Jersey margin (see Poag and Mountain, this volume).

\section{Benthic Foraminiferal Characteristics}

The upper Pliocene/upper Pleistocene contact at Site 612 is marked by several important changes in the benthic foraminiferal assemblages (Fig. 25; Table 6). Ben- 


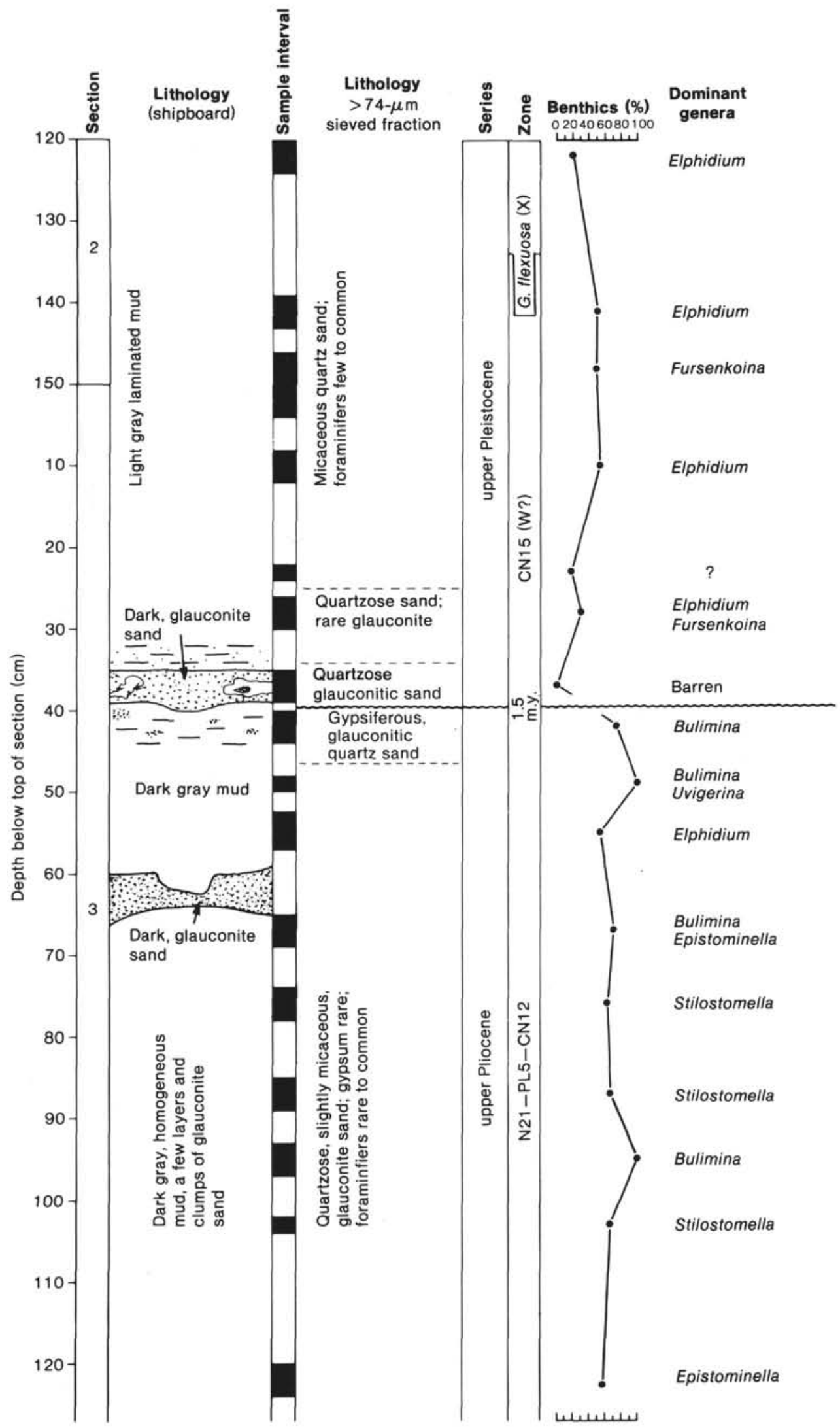

Figure 25. Chart showing the lithic and benthic foraminiferal characteristics across the upper Pliocene/upper Pleistocene contact at Site 612. 
UNCONFORMABLE SEQUENCE BOUNDARIES, SITE 612

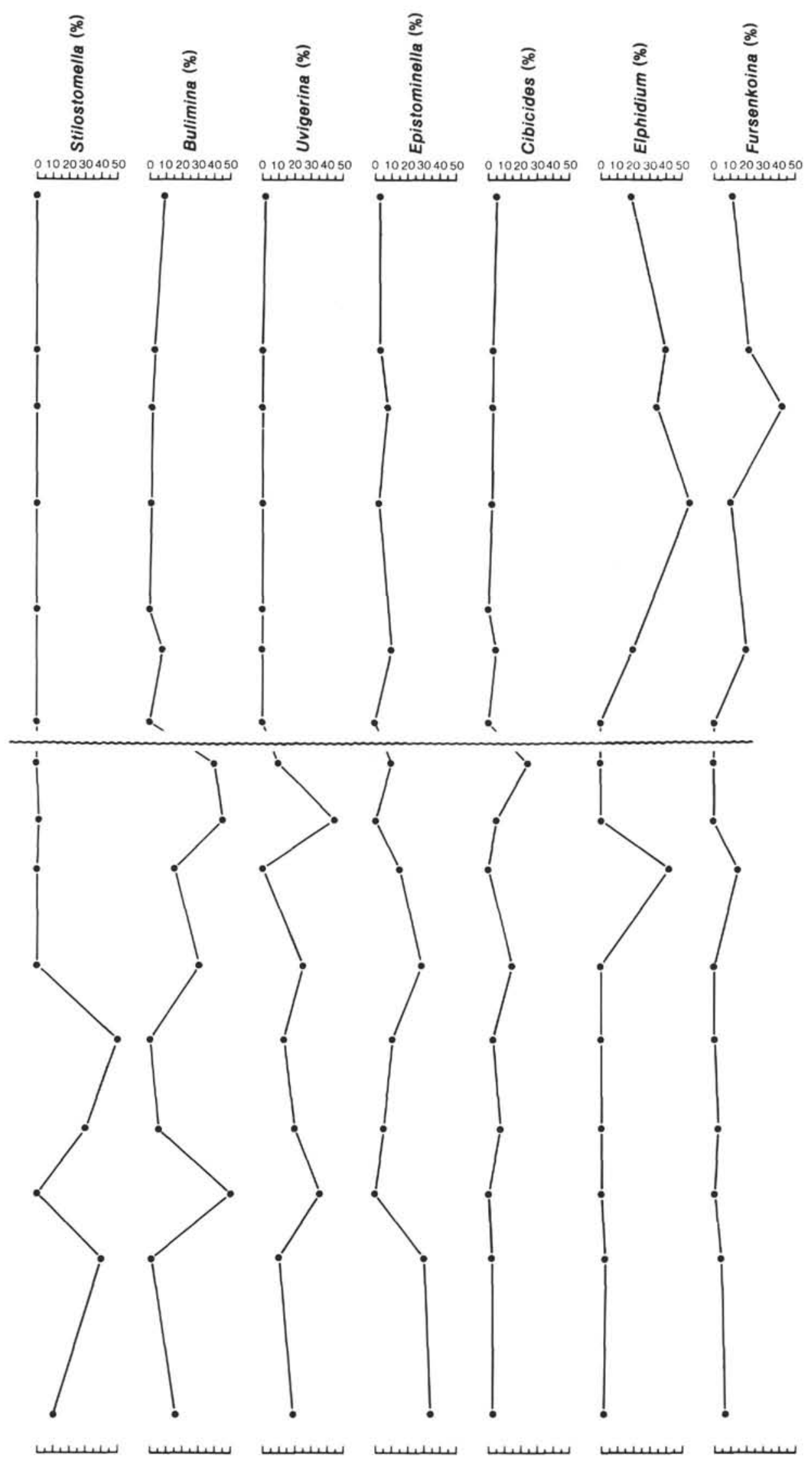

Figure 25 (continued). 
Table 6. Census of benthic foraminiferal genera ( $\%$ of total benthic assemblage $>74 \mu \mathrm{m}$ ).

\begin{tabular}{|c|c|c|c|c|c|c|c|c|c|c|c|c|c|c|c|c|c|}
\hline \multirow[b]{3}{*}{ Genus } & \multicolumn{17}{|c|}{ Sample interval in $\mathrm{cm}$} \\
\hline & \multicolumn{3}{|c|}{$612-5-2$} & \multicolumn{14}{|c|}{$612-5-3$} \\
\hline & $120-124$ & $139-143$ & $146-150$ & $0-4$ & $8-12$ & $22-24$ & $26-30$ & $35-39$ & $40-44$ & $48-50$ & $53-57$ & $65-69$ & 74-78 & $85-89$ & 93-97 & $102-104$ & $120-124$ \\
\hline Bulimina & 7.0 & 2.2 & 1.3 & 3.3 & 1.2 & $-{ }^{a}$ & 7.9 & - & 39.1 & 43.8 & 1.43 & 30.8 & 0.4 & 6.4 & 50.0 & 0.4 & 4.3 \\
\hline Cassidulina & 12.7 & 13.5 & 3.6 & 5.7 & 17.3 & $?$ & 11.8 & - & 4.1 & - & 14.3 & - & 6.1 & 15.2 & - & 5.8 & 13.8 \\
\hline Cibicides & 5.0 & 1.6 & 0.3 & 2.4 & 1.2 & - & 3.9 & - & 24.7 & 3.8 & - & 15.4 & 0.8 & 7.6 & - & 1.8 & 1.6 \\
\hline Elphidium & 17.7 & 41.8 & 34.2 & 22.2 & 54.8 & $?$ & 19.7 & - & - & - & 42.9 & - & - & - & - & 0.4 & 1.6 \\
\hline Epistominella & 4.0 & 2.7 & 8.2 & 6.1 & 1.6 & ? & 9.2 & $\underline{-}$ & 10.3 & - & 14.3 & 30.8 & 9.8 & 5.8 & - & 30.5 & 32.4 \\
\hline Fursenkoina & 12.0 & 21.2 & 42.1 & 25.0 & 11.7 & - & 19.7 & - & - & - & 14.3 & - & - & 1.2 & - & 1.3 & 5.3 \\
\hline Stilostomella & - & - & - & 0.5 & - & - & - & - & 1.0 & 1.3 & - & - & 56.7 & 29.7 & - & 37.2 & 8.0 \\
\hline Uvigerina & 0.3 & - & - & - & - & - & - & - & 8.2 & 46.3 & - & 23.1 & 13.5 & 19.2 & 33.3 & 7.2 & 17.6 \\
\hline Biloculinella & - & 1.1 & - & - & - & - & - & - & - & - & & & & & & & \\
\hline Bolivina & 9.4 & 1.1 & - & 0.5 & .8 & $?$ & - & - & 1.0 & - & - & - & - & - & - & - & 0.5 \\
\hline Buccella & 1.7 & 2.2 & - & 0.9 & 2.4 & - & - & - & 2.1 & - & - & - & 2.9 & 0.6 & - & 4.0 & 1.1 \\
\hline Buliminella & - & - & 0.7 & - & - & - & - & - & - & - & - & - & 0.8 & 0.6 & - & 1.8 & - \\
\hline Cancris & - & - & - & - & - & - & - & - & 2.1 & - & - & - & - & - & - & - & - \\
\hline Eponides & 7.4 & 1.6 & - & 0.5 & - & - & - & - & - & - & - & - & - & - & - & - & - \\
\hline Fissurina & 1.7 & 1.1 & 0.7 & 0.5 & - & - & - & - & - & - & - & - & 0.4 & 1.2 & - & 0.4 & 0.5 \\
\hline Glandulina & - & - & - & - & - & - & - & - & - & - & - & - & - & - & - & 0.9 & 0.5 \\
\hline Globobulimina & 0.3 & - & - & - & 0.4 & - & - & - & - & 3.8 & - & - & - & - & - & - & - \\
\hline Gyroidina & - & - & - & - & - & - & 1.3 & - & - & - & - & - & 0.4 & 2.9 & - & 0.4 & 1.1 \\
\hline Heronallenia & - & 0.5 & - & - & - & - & - & - & - & - & - & - & - & - & - & - & - \\
\hline Hoeglundina & 0.6 & - & - & - & - & $\underline{-}$ & - & - & - & - & - & - & - & - & - & - & - \\
\hline Lagena & - & - & - & 1.4 & - & - & - & - & - & - & - & - & 0.8 & 0.6 & - & 1.3 & - \\
\hline Lenticulina & 0.3 & - & $\underline{-}$ & - & - & - & 1.3 & $\underline{-}$ & - & $\overline{-}$ & - & - & - & - & - & - & - \\
\hline Nodosaria & - & - & - & - & - & - & - & - & - & 1.3 & - & - & - & - & - & - & - \\
\hline Nonionella & 3.3 & 4.3 & 5.3 & 14.2 & 3.2 & $?$ & 6.6 & - & - & - & - & 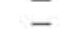 & $\overline{-}$ & 0.6 & 16.7 & $=$ & 0.5 \\
\hline Oridorsalis & 0.3 & - & - & - & - & - & - & - & - & - & - & - & - & - & - & - & - \\
\hline Orthomorphina & - & - & - & - & - & - & - & - & 3.1 & - & - & - & - & - & - & - & - \\
\hline Plectof rondicularia & - & - & $\underline{-}$ & $=$ & $\bar{z}$ & 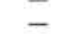 & $\overline{-}$ & - & - & $\underline{-}$ & - & - & 4.9 & 1.2 & - & 0.4 & 1.1 \\
\hline Pleurostomella & - & - & - & - & - & - & - & - & - & - & - & - & - & 0.6 & - & - & 0.5 \\
\hline Pullenia & 10.0 & 1.1 & - & 3.8 & - & - & 6.6 & - & - & - & - & - & 0.4 & 3.5 & - & 2.2 & 7.4 \\
\hline Pyrgo & 0.3 & - & - & - & 0.4 & $?$ & 1.3 & - & - & - & - & - & - & - & - & - & - \\
\hline Quinqueloculina & 1.0 & 1.6 & 3.0 & 1.9 & 3.2 & i & 10.5 & - & - & - & - & - & - & - & - & - & - \\
\hline Quadrimorphina & - & - & - & - & - & - & - & - & - & - & - & - & - & - & - & 0.4 & - \\
\hline Rosalina & 0.3 & - & 0.7 & - & - & - & - & - & - & - & - & - & - & - & - & - & - \\
\hline Sagrina & - & 0.5 & - & - & - & - & - & - & - & - & - & - & - & - & - & - & - \\
\hline Sigmoilopsis & - & 0.5 & - & - & - & - & - & - & - & - & - & - & - & - & - & - & - \\
\hline Stainforthia & 0.3 & - & - & - & - & - & - & - & - & - & - & - & - & - & - & - & - \\
\hline Trifarina & 3.0 & 2.2 & - & 0.5 & 1.2 & - & - & - & - & - & - & - & - & 2.3 & - & 2.2 & 1.1 \\
\hline Triloculina & - & - & - & - & - & $?$ & - & - & - & - & - & - & 0.4 & - & - & - & - \\
\hline Valvulineria & 0.7 & - & - & - & - & - & - & - & 4.1 & - & - & - & 1.6 & 0.6 & - & 0.9 & 1.1 \\
\hline Total specimens & 299 & 184 & 304 & 212 & 248 & 9 & 76 & 0 & 388 & 80 & 28 & 208 & 245 & 343 & 48 & 223 & 188 \\
\hline$\%$ Benthics & 20 & 50 & 47 & 40 & 54 & 21 & 28 & 0 & 76 & 99 & 54 & 72 & 63 & 64 & 98 & 70 & 60 \\
\hline No. of benthic genera & 23 & 18 & 11 & 16 & 14 & 8 & 12 & 0 & 11 & 6 & 5 & 4 & 15 & 18 & 3 & 19 & 19 \\
\hline
\end{tabular}

a - means not present.

thic percentage is particularly high below the contact $(54-99 \%$; mean $75 \%)$ and drops significantly above it $(21-54 \%$; mean $38 \%)$, even though the number of displaced shallow-water specimens (Elphidium, Fursenkoina, Quinqueloculina) is higher above it. Several genera are predominant below the contact. Bulimina and Stilostomella are most consistent, but share predominance in two samples with Uvigerina and Epistominella. Elphidi$u m$, a displaced shallow-water form, is predominant in Sample 612-5-3, 53-57 cm).

The glauconite sand immediately above the contact is barren of microfossils, but they are common in several of the higher samples. Elphidium and Fursenkoina, both displaced shallow-water forms, predominate in most samples above the contact.

In addition to the relative abundance of Bulimina, Uvigerina, and Epistominella below the contact, Cibicides also is most abundant there.

\section{Interpretation}

During deposition of the upper Pliocene-upper Pleistocene interval, Site 612 was located on the lower continental slope, 5-10 km seaward of a distinct shelf break (Fig. 7). During the late Pliocene, terrigenous muds accumulated widely while an occasional downslope dis- placement brought glauconite sand in layers and scattered patches, along with shallow-water benthic foraminifers. A well-oxygenated seafloor is evidenced by the homogenization of the section by infaunal invertebrates. The general composition of the benthic foraminiferal assemblages, containing Bulimina, Stilostomella, Epistominella, and Uvigerina in abundance, points to bathyal depths much like those of today, but the consistent presence of glauconite, quartz sand, and shallow-water foraminifers suggests that water was considerably shallower over the adjacent shelf. The glauconite sand in 612 5-3, 60-65 $\mathrm{cm}$ and the Elphidium assemblage above it (Sample 612-5-3, 53-57 cm), followed by the sudden influx of detrital gypsum aggregates in Sample 612-5-3, $40-44 \mathrm{~cm}$ (just below the Pliocene/Pleistocene contact) suggests a progressive fall of sea level that culminated in a widespread erosional unconformity.

The paleoslope model can not be applied to the upper Pliocene surface, because Site 612 is seaward of the Pliocene shelfbreak (Fig. 7) and because the upper Pliocene stratigraphy and paleoenvironments of the New Jersey Coastal Plain are poorly known (Owens and Sohl, 1969; Olsson, 1978; Jordan and Smith, 1984; Poag, 1984). However, we know that the upper Neogene-Quaternary section (perhaps containing Pliocene strata) of New Jer- 
sey is generally of inner sublittoral, paralic, and alluvial origin (Minard and Rhodehamel, 1969; Olsson, 1978). Thus, the late Pliocene shoreline must have been not far from the present one, and the shelf break was only a few kilometers landward of its present location (Fig. 26). Site 612 would have been in $\sim 1400 \mathrm{~m}$ of water, similar to today's depth.

Following this erosion, a displaced, quartzose, glauconite sand reinitiated deposition at Site 612. Deposition must have been rapid, as no microfossils were incorporated within it. Following emplacement of the glauconite sand, upper Pleistocene terrigenous muds were deposited. These muds differ from the upper Pliocene muds in their lighter color and general lack of glauconite, which is replaced by abundant mica. The benthic foraminiferal assemblages in this Pleistocene section are markedly different from the upper Pliocene ones. Although a background assemblage of Cassidulina, Bulimina, and Epistominella suggest bathyal depths, the dominant component up to $612-5-3,139 \mathrm{~cm}$ is a displaced association of shallow-water shelf forms, such as Elphidium, Fursenkoina, Nonionella, and Buccella. This assemblage, in association with cool-water planktonic species (chiefly $G$. inflata and $N$. pachyderma [dextral]) suggest deposition during a glacial (perhaps Zone $\mathrm{W}$ of the Ericson-Wollin scheme $=$ Stage 6 of oxygen-isotope chronology = Illinoian). At 124 to $120 \mathrm{~cm}$, however, the abundance of warm water Globorotalia flexuosa suggests deposition during Zone $\mathrm{X}$ of the Sangamonian interglacial $(=$ Stage 5 of oxygen-isotope chronology).

Sangamonian strata of the New Jersey Coastal Plain are encompassed by the Cape May Formation, which comprises estuarine sands and clays, shallow marine sands, and deltaic sands (Minard and Rhodehamel, 1969). Marine fossils are most common on Cape May, indicating that the shoreline was near the present one.

\section{Regional Relationships}

Site 612 is the only firm documentation of a fully marine Pleistocene/Pliocene contact yet established in the New Jersey shelf and slope region. Elsewhere, intermittent coring (ASP sites), the presence of unconformities (AMCOR sites), and lack of shallow-depth sampling (commercial and COST wells) prevent analysis of the contact. A distinct seismic discontinuity separates inferred Pliocene from Pleistocene strata over most of the shelf and slope (Poag, 1985a) indicating its regional significance. An equivalent seismic unconformity is also present beneath the continental rise, where it was documented at Sites 604 and 613 (Poag, 1985b).

The upper Pliocene/upper Pleistocene contact at Site 612 corresponds approximately to the contact between supersequences Q and Tf of the Vail model. Vail and Mitchum (1979) assigned the Q/Tf boundary to the Pli-

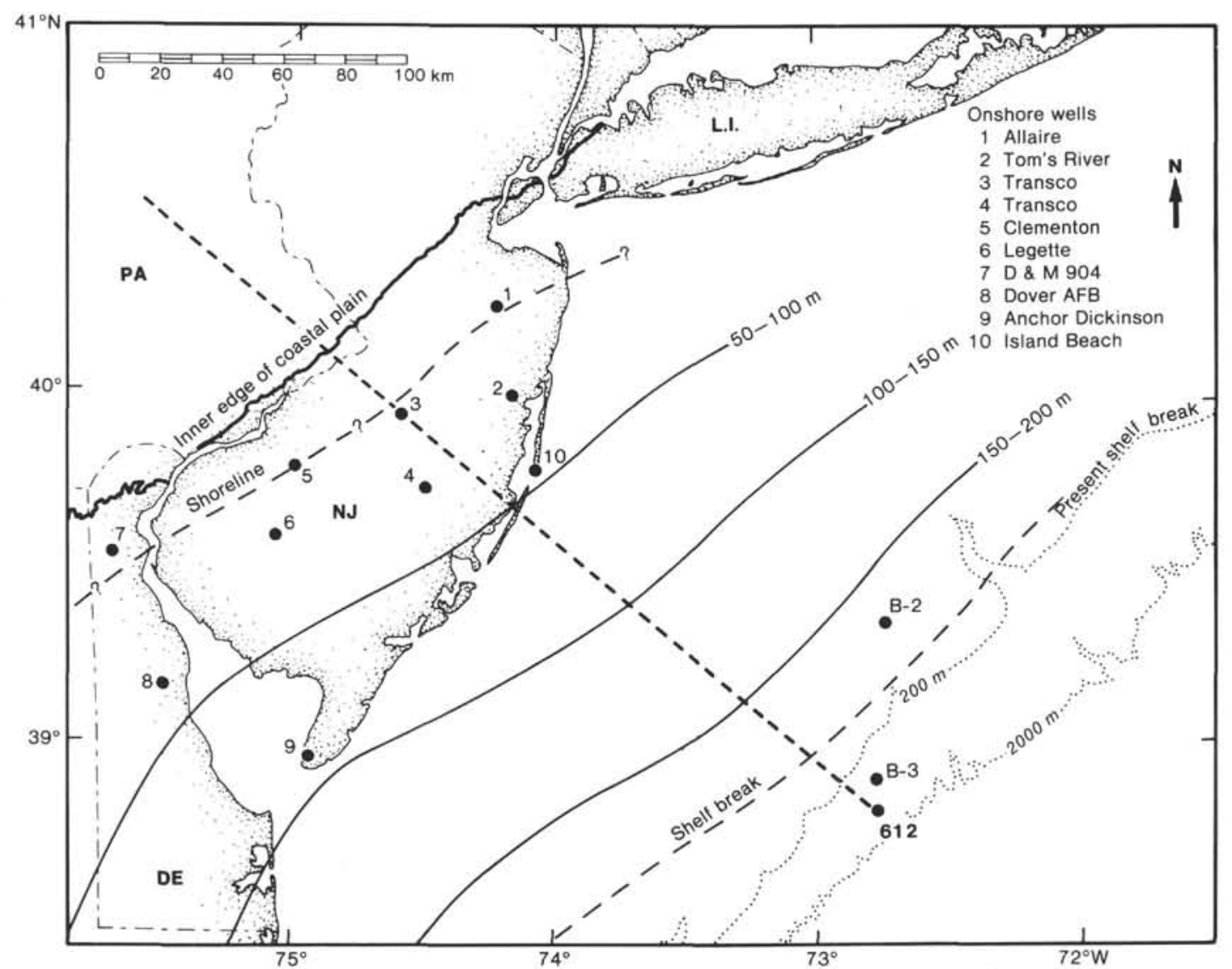

Figure 26. Generalized late Pliocene seafloor morphology based on comparison of benthic foraminiferal assemblages at Site 612 with modern analogs and analysis of two-dimensional geometry along Line 25 . 
ocene/Pleistocene boundary, which they dated at $2.8 \mathrm{Ma}$. This stratigraphic interpretation is peculiar to the Exxon group (e.g., Lamb and Beard, 1972; Stainforth et al., 1975) and has little support elsewhere (e.g., Poag and Valentine, 1976; Haq et al., 1977; Berggren et al., 1980). A variety of recent studies show that the base of the Pleistocene is approximately 1.6 Ma (Berggren et al., 1980). The boundary between supersequences $Q$ and $\mathrm{Tf}$ at $2.8 \mathrm{Ma}$ falls within Zone P15 of Berggren and Van Couvering (1974; Berggren et al., 1980), which is an upper Pliocene level.

Poag and Low (1985) noted an unconformity within middle to upper Pliocene strata at Site 548 on the Goban Spur, which also appears to represent the Q/Tf contact. They originally estimated that the Goban Spur contact was at approximately the $3.8 \mathrm{Ma}$ level, but the imprecision of both nannofossil and foraminiferal zonation at Site 548 could easily accommodate a date of 2.8 Ma.

\section{SUMMARY AND CONCLUSIONS}

Marked changes in lithologic, microfaunal, seismic reflection, and downhole logging characteristics give evidence that seven (and perhaps eight) major sequence boundaries at Site 612 are erosional unconformities. The presence of sand layers or exotic lithoclasts immediately above the scour surface at six of the seven contacts indicates that deposition was reinitiated by a sediment gravity flow, which must have eroded at least a portion of the missing sediment. These relationships are similar to those noted for several equivalent supersequence boundaries on the Goban Spur (Poag and Low, 1985; Poag et al., 1985). The source of sand at the Miocene and younger unconformities of Site 612 could have been almost anywhere on the adjacent shelf and upper slope, as the entire sedimentary section there is chiefly terrigenous detritus (Poag, 1985a). However it is more difficult to explain a quartz sand layer at the middle Eocene/upper Eocene contact, in the midst of a thick carbonate (chalk) section. Presumably this sand was emplaced during a rapid sea-level fall, which brought a siliciclastic shoreline much nearer to Site 612 than during the rest of the Paleogene.

The persistent presence of gravity-flow deposits at the unconformable supersequence boundaries implies a common cause of sediment displacement. Most of the unconformities can be traced onto the adjacent shelf and even onto the coastal plain, where the stratigraphic evidence strongly implicates sea-level fall as that common agent (Fig. 27; Poag and Schlee, 1984; (Ward and Strickland, 1985). Poag et al. (1985) reached a similar conclusion regarding equivalent supersequence boundaries on the Irish continental slope, as did Loutit and Kennett (1981a, 1981b) for New Zealand, and Steele (1976), McGowran (1979) and Quilty (1980) for Australia. The process of slope erosion envisioned by Poag et al. (1985) was depression and elevation of a turbulent water-mass boundary across the continental slope in unison with falling and rising sea level. This was based on the suggestion of Sarnthein et al. (1982) that internal waves and turbulence, caused by density differences at water-mass boundaries, could cause significant erosion where a boundary intersects the seafloor. Stanley et al. (1983) discussed similar relationships regarding water-mass boundaries on the New Jersey margin. They showed that the mudline on the modern New Jersey margin can range from 200 to $1000 \mathrm{~m}$ depending on several variables. Beneath the shelf water mass (shoreline to the shelfbreak), erosion takes place continually from the interplay of storms, fronts, tides, and internal waves. The upper few hundred to $1000 \mathrm{~m}$ below the intersection of the shelf and slope water masses, is a transitional zone of periodic resuspension induced by surface waves, tidal currents, wind-stress currents, internal waves (Southard and Stanley, 1976), and shear forces between major water masses and oceanic fronts (Ruzecki and Welch, 1977; Karl et al., 1983; Pietrafesa, 1983). This alternation of deposition and resuspension triggers sediment flow along the middle and lower slope. A falling sea level would depress the transition zone, causing resuspension and sediment flow even farther down the slope, affecting sites such as 612 .

Deep flowing boundary currents, such as the Gulf Stream and the Western Boundary Undercurrent, also are effective agents for eroding the continental slope and rise (e.g., Tucholke and Mountain, 1979; Pinet and Popenoe, 1982, 1985a, 1985b; Popenoe, 1985; Ledbetter and Balsam, 1985). Geographic and bathymetric shifts of such currents, coincident with sea-level changes, could be of particular importance in forming major unconformities. Such shifts were demonstrated by Ledbetter and Balsam (1985) on the New Jersey margin, where the Western Boundary Undercurrent accelerated, moved shoreward by $\sim 150 \mathrm{~km}$, and shoaled by $\sim 1000 \mathrm{~m}$ (relative to its modern velocity and position) during the last glacial. These data do not apply directly to depths as shallow as Site 612, but a current-swept middle Eocene outcrop belt is only $3 \mathrm{~km}$ downdip from Site 612; it is reasonable to assume that this erosional swath also temporarily shifted updip during glacio-eustatic sea level falls.

At most of the contacts studied, definitive changes in the benthic foraminiferal assemblages and other sedimentary constituents indicate that the seafloor environment changed during the hiatus. Although our analyses do not always point directly to paleobathymetric changes, they do suggest that water mass properties, such as dissolved oxygen content, temperature, and nutrient content, changed considerably, implying that related large scale tectonic or paleoclimatic shifts triggered paleoceanographic responses. The growing body of field data, such as we have presented here (including biostratigraphy, lithostratigraphy, sedimentology, downhole logging, and seismostratigraphy), when integrated with stable isotope analyses, demonstrate a clear link during most of the Cenozoic between widespread shelf and slope (and even abyssal) erosion, increased global ice volumes, cooler global climate, and lowered sea levels (Vail et al., 1977; Frakes, 1979; Miller and Fairbanks, 1983; Keigwin and Keller, 1984; Poag and Schlee, 1984; Poag, 1985a; Poag et al., 1985; Poag and Low, 1985; Miller et al., 1985; Aubry, 


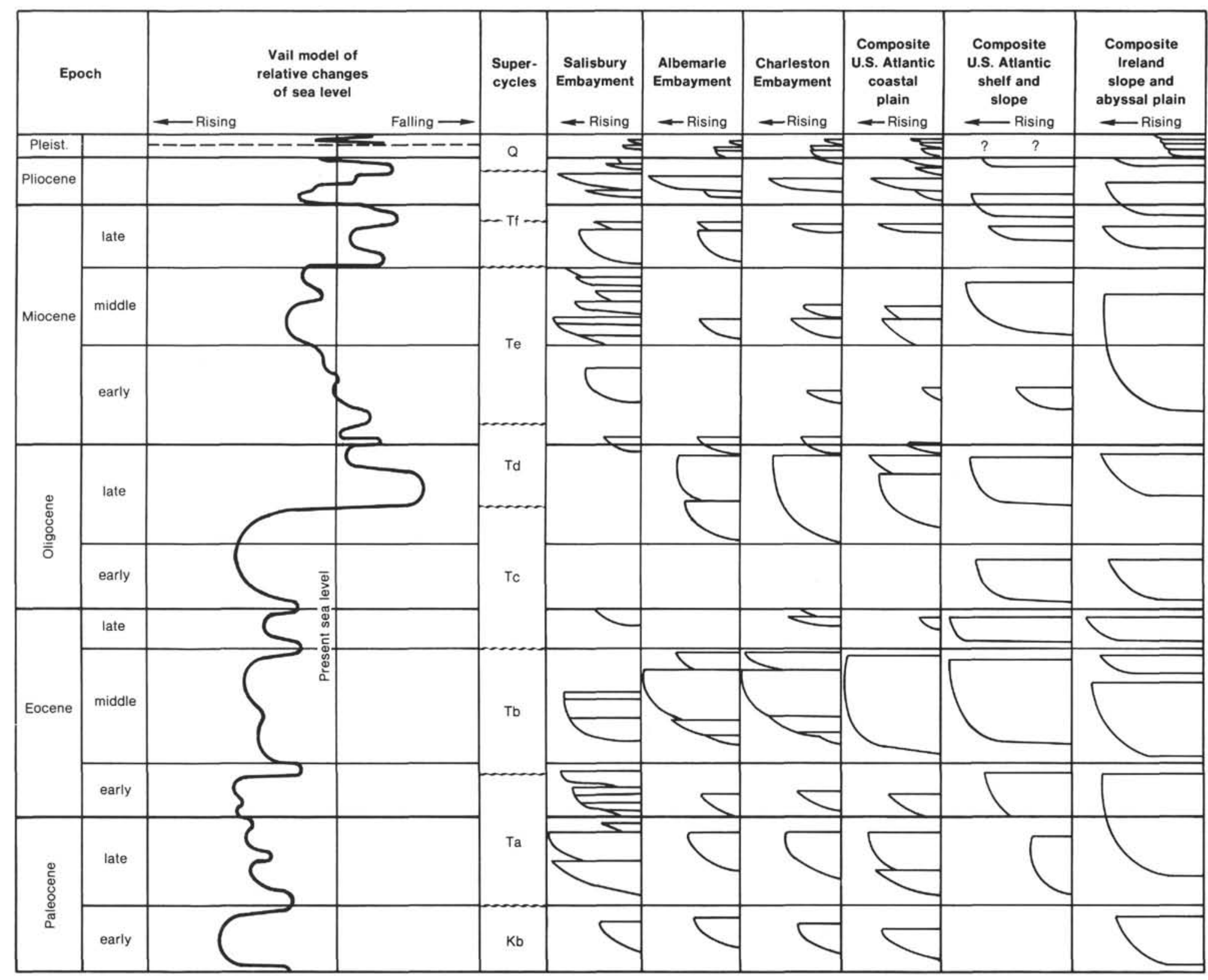

Figure 27. Summary chart showing the relationships of the Cenozoic depositional sequences and stratigraphic gaps of the U.S. Atlantic margin and the Irish margin to the sea-level curve, supercycles, and global unconformities of the Vail depositional model. Data from Vail and Mitchum (1979), Vail and Hardenbol (1979), Ward and Strickland (1985), Poag and Low (1985), and Poag et al. (1985). Wedges represent depositional sequences; note that many lower scale sequences (parasequences of

Vail model) are observed in coastal plain supersequences. 
1985; Woodruff and Savin, 1985). Some authors have interpreted the oxygen-isotope record as an indication that significant global ice volumes were present well into the Late Cretaceous (Matthews and Poore, 1980; Matthews, 1984). Thus, there seems to be no requirement that tectonism played a role in short-cycle sea-level change, as advocated by Pitman (1978), Watts (1982), Watts and Thorne (1984), and Thorne and Watts (1984). On the other hand, there is no a priori reason to assume that a single mechanism was responsible for each supercycle. Tectonism probably was a modifying factor during some intervals, amplifying or damping the effects of ice-volume change.

Our results substantiate the applicability of the Vail depositional model to North Atlantic continental margins, confirming that six of the eight Cenozoic global unconformities are present in this region. We also provide further evidence that a stratigraphic gap between the Campanian and Maestrichtian stages is probably a global phenomenon.

\section{ACKNOWLEDGMENTS}

We thank A. J. Melillo and L. W. Ward for their thoughtful reviews of the original manuscript.

\section{REFERENCES}

Adams, C. G., Benson, R. H., Kidd, R. B., Ryan, W. B. F., and Wright, R. C., 1977. The Messinian salinity crisis and evidence of late Miocene eustatic changes in the world ocean. Nature, 269: 383-386.

Aubry, M.-P., 1985. Northwestern European Paleogene magnetostratigraphy, biostratigraphy, and paleogeography: Calcareous nannofossil evidence. Geology, 13:198-202.

Barr, F. T., and Berggren, W. A., 1981. Lower Tertiary biostratigraphy and tectonics of northeastern Libya. In Solem, M., and Busrewil, M-T. (Eds.), The Geology of Libya (Vol. 1): London (Academic Press), 163-192.

Benson, R. N., Jordan, R. R., and Spoljaric, N., 1985. Geological studies of Cretaceous and Tertiary section, test well Je32-04, central Delaware. Delaware Geol. Surv. Bull., 17:1-69.

Berggren, W. A., and Aubert, J., 1983. Paleogene benthic foraminiferal biostratigraphy and paleobathymetry of the central Coast Ranges of California. In Brabb, E. E. (Ed.), Studies in Tertiary Stratigraphy of the California Coast Ranges. U.S. Geol. Surv. Prof. Pap., 1313:4-21.

Berggren, W. A., Burckle, L. H., Cita, M. B., Cooke, H. B. S., Funnell, B. M., Gartner, S., Hays, J. D., Kennett, J. P., Opdyke, N. D., Pastouret, L., Shackleton, N. J., and Takayanagi, Y., 1980. Towards a Quaternary time scale. Quat. Res., 13:277-302.

Berggren, W. A., Kent, D. V., Flynn, J. J., and Van Couvering, J. A., 1985. Cenozoic geochronology. Geol. Soc. Am. Bull., 96:14071418 .

Berggren, W. A., and Schnitker, D., 1983. Cenozoic marine environments in the North Atlantic and Norwegian-Greenland Sea. In Bott, M., Saxov, S., Talwani, M., and Thiede, J. (Eds.), Structure and Development of the Greenland-Scotland Ridge: London (Plenum Press), pp. 495-547.

Berggren, W. A., and Van Couvering, J. A., 1974. The late Neogenebiostratigraphy, geochronology and paleoclimatology of the last 15 million years in marine and continental sequences. Developments in Paleontology and Stratigraphy (Vol. 2): New York (Elsevier Scientific), 1-216.

Blow, W. H., 1979. The Cainozoic Globigerinida: Leiden (E. J. Brill).

Charletta, A. C., 1980. Eocene benthic foraminiferal paleoecology and paleobathymetry of the New Jersey continental margin [Ph.D. thesis]. Rutgers Univ., New Brunswick, NJ.

Douglas, R. G., 1979. Benthic foraminiferal ecology and paleoecology; A review of concepts and methods. Foraminiferal Ecology and
Paleoecology. Soc. Econ. Paleontol. Mineral. Short Course No. 6, Houston, Texas, pp. 21-53.

Douglas, R. G., and Woodruff, F., 1981. Deep-sea benthic foraminifera. In Emiliani, C. (Ed.), The Sea (Vol. 7): The Oceanic Lithosphere: New York (Wiley Interscience), 1233-1327.

Ericson, D. B., and Wollin, G., 1968. Pleistocene climates and chronology in deep-sea sediments. Science, 162:1227-1234.

Farre, J. A., 1985. The importance of mass wasting processes on the continental slope [Ph.D. thesis]. Columbia University, New York.

Farre, J. A., and Ryan, W. B. F., 1985. 3-D view of erosional scars on U.S. mid-Atlantic continental margin. Am. Assoc. Pet. Geol. Bull., 69:923-932.

Frakes, L. A., 1979. Climates throughout Geologic Time: New York (Elsevier).

Graciansky, P. C. de, Poag, C. W., et al., 1985a. The Goban Spur Transect: Geologic evolution of a sediment-starved passive continental margin. Geol. Soc. Am. Bull., 96:58-76.

1985b. Init. Repts. DSDP, 80: Washington (U.S. Govt. Printing Office).

Grow, J. A., 1980. Deep structure and evolution of the Baltimore Canyon trough in the vicinity of the COST No. B-3 well. In Scholle, P. A. (Ed.), Geological Studies of the COST No. B-3 Well, United States Mid-Atlantic Continental Slope Area. U.S. Geol. Surv. Circ., 833:117-125.

Hampson, J. C., and Robb, J. M., 1984. A geologic map of the continental slope off New Jersey; Lindenkohl Canyon to Toms Canyon. U.S. Geol. Surv. Misc. Invest. Series, I-1608.

Hancock, J. M., and Kauffman, E. G., 1979. The great transgressions of the Late Cretaceous. J. Geol. Soc. London, 136:175-186.

Haq, B. U., Berggren, W. A., and Van Couvering, J. A., 1977. Corrected age of the Pliocene/Pleistocene boundary. Nature, 269: 483-488.

Harris, P. M., Frost, S. H., Seiglie, G. A., and Schneidermann, N., 1984 Regional unconformities and depositional cycles, Cretaceous of the Arabian Peninsula. In Schlee, J. S. (Ed.), Interregional Unconformities and Hydrocarbon Accumulation. Am Assoc. Pet. Geol. Mem., 36:67-80.

Hollister, C. D., Ewing, J. I., et al., 1972. Init. Repts. DSDP, 11: Washington (U. S. Govt. Printing Office).

Hsü, K. J., Montadert, L., Bernoulli, D., Cita, M. B., Enkson, A., Garrison, R. E., Kidd, R. B., Mélières, F., Müller, C., and Wright, R., 1977. History of the Mediterranean salinity crisis. Nature, 267: 399-403.

Jordan, R. R., and Smith, R. V., (Coordinators), 1984. Atlantic Coastal Plain: Correlation of stratigraphic units of North America (COSUNA) Project. Amer. Assoc. Petrol. Geol., 1 chart.

Karl, H. A., Carlson, P. R., and Cacchione, D. A., 1983. Factors that influence sediment transport at the shelfbreak. In Stanley, D. J., and Moore, G. T. (Eds. ), The Shelfbreak: Critical Interface on Continental Margins. Soc. Econ. Paleontol. Mineral. Spec. Publ., 33:219-231.

Keigwin, L. D., and Keller, G., 1984. Middle Oligocene climatic change from equatorial Pacific Site 77. Geology, 12:16-19.

Kennett, J. P., and Huddlestun, P., 1972. Late Pleistocene paleoclimatology, foraminiferal biostratigraphy and tephrochronology, western Gulf of Mexico. Quat. Res., 2:38-69.

Kennett, J. P., and Srinivasan, S., 1983. Neogene Planktonic Foraminifera: A Phylogenetic Atlas: Stroudsburg, PA (Hutchinson Ross).

Lamb, J. L., and Beard, J. H., 1972. Late Neogene planktonic foraminifers in the Caribbean, Gulf of Mexico, and Italian stratotypes. Univ. Kansas Paleontol. Contrib., Art., 57(Protozoa 8):1-67.

Ledbetter, M. T., and Balsam, W. L., 1985. Paleoceanography of the Deep Western Boundary Undercurrent on the North American continental margin for the Past 25,000 yr. Geology, 13:181-184.

Loutit, T. S., and Kennett, J. P., 1981a. New Zealand and Australian Cenozoic sedimentary cycles and global sea-level changes. $\mathrm{Am}$. Assoc. Pet. Geol. Bull., 65:1586-1601.

1981b. Australiasian Cenozoic sedimentary cycles, global sea level changes and the deep sea sedimentary record. Oceanol. Acta (suppl.), 4:45-63.

McGowran, B., 1979. The Tertiary of Australia: Foraminiferal overview. Mar. Micropaleontol., 4:235-264.

Matthews, R. K., 1984. Oxygen isotope record of ice-volume history: 100 million years of glacio-eustatic sea-level. In Schlee, J. S. (Ed.), 
Interregional Unconformities and Hydrocarbon Accumulation. Am. Assoc. Petrol. Geol. Mem., 36:97-107.

Matthews, R. K., and Poore, R. Z., 1980. Tertiary $\delta^{18} \mathrm{O}$ record and glacio-eustatic sea-level fluctuations. Geology, 8:501-504.

Miller, K. G., and Fairbanks, R. G., 1983. Evidence for Oligocenemiddle Miocene abyssal circulation changes in the western North Atlantic. Nature, 306:250-253.

Miller, K. G., Mountain, G. S., and Tucholke, B. E., 1985. Oligocene glacio-eustasy and erosion on the margins of the North Atlantic. Geology, 13:10-13.

Minard, J. P., and Rhodehamel, E. C., 1969. Quaternary geology of part of northern New Jersey and the Trenton area. In Subitzky, S. (Ed.), Geology of Selected Areas in New Jersey and Eastern Pennsylvania: New Brunswick, NJ (Rutgers Univ. Press), pp. 279-313.

Mountain, G. S., and Tucholke, B. E., 1985. Mesozoic and Cenozoic geology of the U.S. Atlantic continental slope and rise. In Poag, C. W. (Ed.), Geologic Evolution of the United States Atlantic Margin: New York (Van Nostrand Reinhold), pp. 293-341.

Nyong, E. E., and Olsson, R. K., 1984. A paleoslope model of Campanian to lower Maestrichtian foraminifera in the North American basin and adjacent continental margin. Mar. Micropaleontol., 8: 437-477.

Olsson, R. K., 1978. Summary of lithostratigraphy and biostratigraphy of Atlantic Coastal Plain (northern part). In Benson, W. E., Sheridan, R. E., et al., Init. Repts. DSDP, 44: Washington (U.S. Govt. Printing Office), 941-947.

Olsson, R. K., Miller, K. G., and Ungrady, T. E., 1980. Late Oligocene transgression of middle Atlantic Coastal Plain. Geology, 8: 549-554.

Olsson, R. K., and Nyong, E. E., 1984. A paleoslope model for Campanian-lower Maestrichtian foraminifera of New Jersey and Delaware. J. Foram. Res., 14:50-68.

Owens, J. P., and Gohn, G. S., 1985. Depositional history of the Cretaceous Series in the U.S. Atlantic Coastal Plain: Stratigraphy, paleoenvironments, and tectonic controls of sedimentation. In Poag, C. W. (Ed.), Geologic Evolution of the United States Atlantic Margin: New York (Van Nostrand Reinhold), pp. 25-86.

Owens, J. P., and Sohl, N. F., 1969. Shelf and deltaic paleoenvironments in the Cretaceous-Tertiary formations of the New Jersey Coastal Plain. In Subitzky, S. (Ed.), Geology of Selected Areas in New Jersey and Eastern Pennsylvania and Guidebook of Excursions: New Brunswick, NJ (Rutgers Univ. Press), pp. 235-278.

Palmer, A. A., 1983. Biostratigraphic and paleoenvironmental results from Neogene radiolarians, U.S. Mid-Atlantic Coastal Plain and continental margin. Am. Assoc. Pet. Geol. Bull., 67:528-529.

Pietrafesa, L. J., 1983. Shelfbreak circulation, fronts, and physical oceanography: East and west coast perspectives. In Stanley, D. J., and Moore, G. T. (Eds.), The Shelfbreak: Critical Interface on Continental Margins. Soc. Econ. Paleontol. Mineral. Spec. Publ., 33:233-250.

Pinet, P. R., and Popenoe, P., 1982. Blake Plateau: Control of Miocene sedimentation patterns by large-scale shifts of the Gulf Stream axis. Geology, 10:257-259.

1985a. Shallow seismic stratigraphy and post-Albian geologic history of the northern and central Blake Plateau. Geol. Soc. Am. Bull., 96:627-638.

1985b. A scenario of Mesozoic-Cenozoic ocean circulation over the Blake Plateau and its environs. Geol. Soc. Am. Bull., 96: 618-626.

Pitman, W. C. III, 1978. Relationship between eustacy and stratigraphic sequences of passive margins. Geol. Soc. Am. Bull., 89:1389-1403.

Poag, C. W., 1980. Foraminiferal biostratigraphy, paleoenvironments, and depositional cycles in the Baltimore Canyon Trough. In Scholle, P. A. (Ed.), Geologic Studies of the COST No. B-3 Well, United States Mid-Atlantic Continental Slope Area. U.S. Geol. Surv. Circ., 833:44-65.

1984. Neogene stratigraphy of the submerged U.S. Atlantic margin. Palaeogeogr., Palaeoclimatol., Palaeoecol., 47:103-127.

1985a. Depositional history and stratigraphic reference section for central Baltimore Canyon trough. In Poag, C. W. (Ed.), Geologic Evolution of the United States Atlantic Margin: New York (Van Nostrand Reinhold), pp. 217-263.

1985b. Cenozoic and Upper Cretaceous sedimentary facies and depositional systems of the New Jersey slope and rise. In Poag,
C. W. (Ed.), Geologic Evolution of the United States Atlantic Margin: New York (Van Nostrand Reinhold), pp. 343-365.

$1985 \mathrm{c}$. Benthic foraminifera as indicators of potential petroleum sources. In Perkins, B. F., and Martin, G. B. (Eds.), Habitat of Oil and Gas in the Gulf Coast. Proc. Fourth Ann. Res. Conf., Gulf Coast Sect., Soc. Econom. Paleont. Mineral. Found., pp. $275-284$.

Poag, C. W., and Hall, R. E., 1979. Foraminiferal biostratigraphy, paleoecology, and sediment accumulation rates. In Scholle, P. A. (Ed.), Geological Studies of the COST GE-1 Well, United States South Atlantic Outer Continental Shelf Area: U.S. Geol. Surv. Circ. 800 , pp. 49-63.

Poag, C. W., and Low, D., 1985. Paleoenvironmental trends among Neogene benthic foraminifers at DSDP Site 548, Irish continental margin. In Graciansky, P. C. de, Poag, C. W., et al., Init. Repts. $D S D P, 80$, Pt. 1: Washington (U.S. Govt. Printing Office), pp. 489-504.

Poag, C. W., Reynolds, L. A., Mazzullo, J., and Keigwin, L. D. Jr., 1985. Foraminiferal, lithic, and isotopic changes across four major unconformities at DSDP Site 548, Goban-Spur. In Graciansky, P. C. de, Poag, C. W., et al., Init. Repts. DDSP, 80, Pt. 1: Washington (U.S. Govt. Printing Office), pp. 539-556.

Poag, C. W., and Schlee, J. S., 1984. Depositional sequences and stratigraphic gaps on submerged United States Atlantic margin. In Schlee, J. S. (Ed.), Interregional Unconformities and Hydrocarbon Accumulation. Am. Assoc. Pet. Geol. Mem., 36:165-182.

Poag, C. W., and Valentine, P. C., 1976. Biostratigraphy and ecostratigraphy of the Pleistocene basin: Texas-Louisiana Continental Shelf. Gulf Coast Assoc. Geol. Soc., Trans., 26:185-256.

Popenoe, P., 1985. Cenozoic depositional and structural history of the North Carolina margin from seismic-stratigraphic analyses. In Poag, C. W. (Ed.), Geologic Evolution of the United States Atlantic Margin: New York (Van Nostrand Reinhold), pp. 125-187.

Quilty, P. G., 1980. Sedimentation cycles in the Cretaceous and Cenozoic of Western Australia. Tectonophysics, 63:349-366.

Riggs, S. R., 1984. Paleoceanographic model of Neogene phosphorite deposition, U.S. Atlantic Continental Margin. Science, 223:123131 .

Robb, J. M., Kirby, J. R., Hampson, J. C., Jr., Gibson, P. R., and Hecker, B., 1983. Furrowed outcrops of Eocene chalk on the lower continental slope offshore New Jersey. Geology, 11:182-186.

Rögl, F., and Hochuli, P., 1976. The occurrence of Bolboforma, a probable algal cyst, in the Antarctic Miocene of DSDP Leg 95. In Hollister, C. D., Craddock, C., et al., Init. Repts. DSDP, 35: Washington (U.S. Govt. Printing Office), 713-719.

Ruzecki, E. P., and Welch, C. S., 1977. Description of shelf waterslope water fronts in the Middle Atlantic Bight. Am. Geophys. Union Trans., 48:888.

Sanfilippo, A., Westburg-Smith, M. J., and Riedel, W. R., 1985. Cenozoic Radiolaria. In Bolli, H. M., Saunders, J. B., and PerchNielsen, K. (Eds.), Plankton Stratigraphy: Cambridge (Cambridge Univ. Press), pp. 631-712.

Sarnthein, M., Thiede, J., Pflaumann, U., Erlenkeuser, H., Fütterer, D., Koopmann, B., Lange, H., and Seibold, E., 1982. Atmospheric and oceanic circulation patterns off northwest Africa during the past 25 million years. In von Rad, U., Hinz, K., Sarnthein, M., and Seibold, E. (Eds.), Geology of the Northwest African Continental Margin: Berlin (Springer-Verlag), pp. 584-604.

Schlee, J. S.,1984. Interregional unconformities and hydrocarbon accumulation. Am. Assoc. Pet. Geol. Mem., 36:1-184.

Seiglie, G. A., and Baker, M. B., 1984. Relative sea-level changes during the Middle and Late Cretaceous from Zaire to Cameroon (Central West Africa). In Schlee, J. S. (Ed.), Interregional Unconformities and Hydrocarbon Accumulation. Am. Assoc. Pet. Geol. Mem., $36: 81-88$.

Seiglie, G. A., and Moussa, M. T., 1984. Late Oligocene-Pliocene transgressive-regressive cycles of sedimentation in northwestern Puerto Rico. In Schlee, J. S. (Ed.), Interregional Unconformities and Hydrocarbon Accumulation. Am. Assoc. Pet. Geol. Mem., 36:89-95.

Sliter, W. V., and Baker, R. A., 1972. Cretaceous bathymetric distribution of benthic foraminifera. J. Foram. Res., 2:167-183.

Snyder, S. W., and Waters, V. J., 1985. Cenozoic planktonic foraminiferal biostratigraphy of the Goban Spur region, Deep Sea Drill- 
ing Project Leg 80. In Graciansky, P. C. de, Poag, C. W., et al., Init. Repts. DSDP, 80, Pt. 1: Washington (U.S. Govt. Printing Office), 439-472.

Southard, J. B., and Stanley, D. J., 1976. Shelfbreak processes and sedimentation. In Stanley, D. J., and Swift, D. J. P. (Eds.), Marine Sediment Transport and Environmental Management: New York (Wiley Interscience), pp. 351-377.

Stainforth, R. M., Lamb, J. L., Luterbacher, H., Beard, J. H., and Jeffords, R. M., 1975. Cenozoic planktonic foraminiferal zonation and characteristics of index forms. Univ. Kansas Paleon. Contrib., Art., 62:1-162.

Stanley, D. J., Addy, S. K., and Behrens, E. W., 1983. The mudline: Variability of its position relative to shelfbreak. In Stanley, D. J., and Moore, G. T. (Eds.), The Shelfbreak: Critical Interface on Continental Margins. Soc. Econ. Paleontol. Mineral. Spec. Publ., 33:279-298.

Steele, R. J., 1976. Some concepts of seismic stratigraphy with application to the Gippsland basin. Australian Petrol. Explor. Assoc. Jour., 16:67-71.

Theyer, F., Mato, C. Y., and Hammond, S. R., 1978. Paleomagnetic and geochronologic calibration of latest Oligocene to Pliocene radiolarian events, equatorial Pacific. Mar. Micropaleontol., 3:377395.

Thorne, J., and Watts, A. B., 1984. Seismic reflectors and unconformities at passive continental margins. Nature, 311:365-368.

Tucholke, B. E., and Mountain, G. S., 1979. Seismic stratigraphy, lithostratigraphy, and paleosedimentation patterns in the North American 56 basin. In Talwani, M., Hay, W. W., and Ryan, W. B. F. (Eds.), Deep Drilling Results in the Atlantic Ocean: Continental Margins and Paleoenvironments: Washington, D. C. (Am. Geophys. Union), Maurice Ewing Series, 3:58-86.

Vail, P. R., and Hardenbol, J., 1979. Sea-level changes during the Tertiary. Oceanus, 22:71-79.

Vail, P. R., Hardenbol, J., and Todd, R. G., 1984. Jurassic unconformities, chronostratigraphy, and sea-level changes from seismic stratigraphy and biostratigraphy. In Schlee, J. S. (Ed.), Interregional Unconformities and Hydrocarbon Accumulation. Am. Assoc. Pet. Geol., Mem., 36:129-144.

Vail, P. R., and Mitchum, R. M., Jr., 1979. Global cycles of relative changes of sea level from seismic stratigraphy. In Watkins, J. S., Montadert, L., and Dickerson, P. W. (Eds.), Geological and Geophysical Investigations of Continental Margins. Am. Assoc. Pet. Geol., Mem., 29:469-472.
Vail, P. R., Mitchum, R. M., Jr., and Thompson, S., III, 1977. Seismic stratigraphy and global changes of sea level. Part Four: Global cycles of relative changes of sea level. In Payton, C. E. (Ed.), Seismic Stratigraphy-Applications to Hydrocarbon Exploration. Am. Assoc. Pet. Geol., Mem., 26:83-98.

Ward, L. W., 1984. Stratigraphy of outcropping Tertiary beds along the Pamunkey River-Central Virginia Coastal Plain. In Ward, L. W., and Krafft, K. (Eds.), Stratigraphy and Paleontology of the Outcropping 'Tertiary Beds in the Pamunkey River Region, Central Virginia Coastal Plain. Guidebook for the 1984 Field Trip, Atlantic Coastal Plain Geol. Assoc., pp. 11-78.

Ward, L. W., and Blackwelder, B. W., 1980. Stratigraphic revision of upper Miocene and lower Pliocene beds of the Chesapeake Group, middle Atlantic Coastal Plain. U.S. Geol. Surv. Bull., 1482-D:1-61.

Ward, L. W., and Strickland, G. L., 1985. Outline of Tertiary stratigraphy and depositional history of the U.S. Atlantic Coastal Plain. In Poag, C. W. (Ed.), Geologic Evolution of the United States Atlantic Margin: New York (Van Nostrand Reinhold), pp. 87-123.

Watts, A. B., 1982. Tectonic subsidence, flexure, and global changes of sea level. Nature, 297:469-474.

Watts, A. B., and Steckler, M. S., 1979. Subsidence and eustacy at the continental margin of eastern North America. In Talwani, M., Hay, W. W., and Ryan, W. B. F. (Eds.), Deep Drilling Results in the Atlantic Ocean: Continental Margins and Paleoenvironments (Am. Geophys. Union), Maurice Ewing Series 3:273-310.

Watts, A. B., and Thorne, J., 1984. Tectonics, global changes in sea level, and their relationship to stratigraphical sequences at the U.S. Atlantic continental margin. Mar. Petrol. Geol., 1:319-339.

Weimer, R. J., 1984. Relation of unconformities, tectonics, and sealevel changes, Cretaceous of Western Interior, U.S.A. In Schlee, J. S. (Ed.), Interregional Unconformities and Hydrocarbon Accumulation. Am. Assoc. Pet. Geol., Mem., 36:7-35.

Woodruff, F., and Douglas, R. G., 1981. Response of deep-sea benthic foraminifera to Miocene paleoclimatic events, DSDP Site 289. Mar. Micropaleontol., 6:617-632.

Woodruff, F., and Savin, S. M., 1985. $\delta^{13}$ C values of Miocene Pacific benthic foraminifera: Correlations with sea level and biological productivity. Geology, 13:119-122.

Ziegler, P. A., 1982. Geological atlas of western and central Europe: The Hague (Shell Internat. Petrol. Maatsch. B. V.).

Date of Initial Receipt: 25 July 1985

Date of Acceptance: 30 April 1986 